\title{
Academic Freedom and Its Protection in the Law of European States
}

\section{Measuring an International Human Right}

\author{
Klaus D. Beiter \\ Associate Professor, North-West University (Potchefstroom Campus), \\ Faculty of Law, South Africa \\ Klaus.Beiter@nwu.ac.za \\ Terence Karran \\ Professor of Higher Education Policy, School of Education, \\ University of Lincoln, uk \\ TerenceK@lincoln.ac.uk \\ Kwadwo Appiagyei-Atua \\ Senior Lecturer, University of Ghana, School of Law, Ghana \\ KAppiagyeiAtua@ug.edu.gh
}

\begin{abstract}
Focusing on those countries that are members of the European Union, it may be noted that these countries are bound under international human rights agreements, such as the International Covenants on Civil and Political, andEconomic, Social and Cultural

* Klaus D. Beiter, B.Iur. LL.B. (unisa, Pretoria), Dr. iur. (lmu Munich). The author wishes to thank the European Commission for its award of a Marie Curie Intra-European Fellowship under its Seventh Framework Programme for research funding, enabling the author to complete work on the project 'Safeguarding Academic Freedom in Europe' at the University of Lincoln, uk.

$\uparrow$ Terence Karran, B.Sc. (Economics and Sociology) Joint Honours, Aberystwyth, PhD Government, University of Manchester.

$\$$ Kwadwo Appiagyei-Atua, LL.B. (Univ. of Ghana, Legon), BL (Ghana School of Law), LL.M. (Dalhousie Univ., Canada), DCL (McGill Univ., Canada). The author wishes to thank the European Commission for its award of a Marie Curie International Incoming Fellowshipunderits Seventh Framework Programme, enabling the author to complete work on the project 'Building Academic Freedom and Democracy in Africa' at the University of Lincoln, uk.
\end{abstract}


Rights or the European Convention on Human Rights, to safeguard academic freedom under provisions providing for the right to freedom of expression, the right to education, and respect for 'the freedom indispensable for scientific research.' unesco's Recommendation concerning the Status of Higher-Education Teaching Personnel, a 'soft-law' document of 1997, concretises international human rights requirements to be complied with to make the protection of the right to academic freedom effective. Relying on a set of human rights indicators, the present article assesses the extent to which the constitutions, laws on higher education, and other relevant legislation of eu states implement the Recommendation's criteria. The situation of academic freedom in practice will not be assessed here. The results for the various countries have been quantified and countries ranked in accordance with 'their performance.' The assessment demonstrates that, overall, the state of the protection of the right to academic freedom in the law of European states is one of 'ill-health.' Institutional autonomy is being misconstrued as exhausting the concept of academic freedom, self-governance in higher education institutions sacrificed for 'executive-style' management, and employment security abrogated to cater for 'changing employment needs' in higher education.

\section{Keywords}

academic freedom-institutional autonomy-self-governance-tenure-international human rights law - unesco Recommendation concerning the Status of HigherEducation Teaching Personnel of 1997- legal protection of academic freedom in eu states

\section{Introduction}

In two articles published in 2007 and 2009, respectively, Terence Karran had analysed whether the then 23 Member States of the European Union provided a high, medium or low level of protection of the right to academic freedom,1 alternatively, whether they complied fully, partially or not at all with it.2 Karran chose parameters of measurement based on notably unesco's Recommendation concerning the Status of Higher-Education Teaching Personnel of 1997. He considered his assessment to be a preliminary one

1 T. Karran, 'Academic Freedom in Europe: A Preliminary Comparative Analysis,' Higher Education Policy 20(3) (2007) 289-313.

2 T. Karran, 'Academic Freedom in Europe: Reviewing unesco's Recommendation,' British Journal of Educational Studies 57(2) (2009) 191-215. 
in that it addresses the constitutional and legislative frameworks in relation to academic freedom, thereby establishing the basis for subsequent empirical work to examine how the concept is interpreted and perceived by academic staff undertaking their day to day work within Europe's universities.3

The latterday-to-day experience of academicfreedombyacademic staffinEuropean universities is indeed currently being scrutinised by the authors, and will be reported on in subsequent publications. However, little did the authors know at the time of Karran'sassessment that the 'redesigning' of highereducation ('he') in European countries - and the concomitant modification of he legislation this would entail - would be pursued at such a speed and with such a vehemence.

National constitutions and he laws in Europe continue emphasising the importance of the right to academic freedom. A closer look at the detail of he law, however, reveals that the eloquent commitments to academic freedom contained in bills of rights or the introductory sections of he laws in truth increasingly merely pay lip-service to this important right once held in esteem in most parts of Europe. Ever since Karran has published his findings, there have been significant changes in the legislation on he in many European countries, enhancing levels of autonomy (or, what policy-makers consider to constitute autonomy) of he institutions, and limiting the extent to which academic staff are involved in the governance (or 'management,' as it has become accustomed to be called) of institutions, reducing the scope of their participation in strategic decision-making, while simultaneously increasing that of rectors (rectorates) (and deans/heads of departments) and external 'experts.' Moreover, the law regulating conditions of employment of academic staff in heis more and more guided by notions of 'flexibilisation,' legitimising the conclusion of fixed-term contracts of service (without long-term perspectives) also at post-entry levels of the academic career, and assuring that contracts of service can be terminated on operational grounds without restraint.

Hence, in the light of these circumstances - and before commenting on the assessment of the de facto situation of academic freedom in Europe - it is meaningful to undertake a renewed assessment of the state of health of the right to academic freedom in the law of the now 28 eu MemberStates, 4 relying

3 Karran (n 1) 289.

4 It may well be asked why the article does not rather focus on states in their capacity as Member States of the Council of Europe, which as a regional organisation focuses on the 
essentially on the standards of unesco's Recommendation. This article relies on the parameters of the right to academic freedom used by Karran (i.e., 1. the protection of 'academic freedom' in the constitution or other legislation, 2. the autonomy of institutions of he, 3 . academic self-governance, and 4. academic tenure), adding a fifth: the ratification of international agreements relevant to the protection of the right to academic freedom. The analysis has, moreover, been refined by defining 37 specific indicators to measure compliance by individual states. The focus, naturally, has been on defining human rights indicators, i.e. indicators operationalising the requirements of the right to academic freedom as protected under international human rights law. The approach has been to accord a numeric value to each indicator in accordance with its relative weight as adjudged under international human rights law. Adding up the scores of states for each of these values makes it possible to rank states regarding five core aspects, but also overall in their protection of the right to academic freedom.

As for the structure of the article, Part 2 outlines the nature of the requirement of legislation applied in assessing the 'legal' protection of the right to academic freedom. Part 3 comments on the right to academic freedom as protected under international human rights law.Part 4 focuses specifically on unesco's Recommendation concerning the Status of Higher-Education Teaching Personnel of 1997 and its provisions on academicfreedom. Part 5 touches on the issue of the legitimacy of using indicators and rankings in determining compliance with human rights standards. Part 6 presents the standard scorecard developed 'to measure' the legal protection of the right to academic freedom in each of the 28 eu states. Part 7 refers to the modus operandi applied and some of the practical difficulties encountered in the assessment exercise. Part 8 reflects the results of the actual assessment for each of five main categories of assessment (incorporating the five parameters mentioned above), and also overall, for eu states. Based on the results, Part 9 then comments on the state of health of the legal protection of the right to academic freedom in Europe, and Part 10 explains the extent to which the findings may be viewed as reflecting violations of the right to academic freedom and also the right to education.

promotion of human rights as one of its primary tasks, the eu's role rather being to facilitate the economic and, to a more limited extent, the political integration of its members. The reason simply is that it would have exceeded available resources to study the legal situation in 47 states at very different stages of development as opposed to that in 28 more or less homogeneous states. 


\section{Assessing the 'Legal' Protection of the Right to Academic Freedom: The Requirement of Legislation}

This article is written in the context of a larger project on the right to academic freedom conducted at the University of Lincoln, uk, examining the doctrinal basis of the right to academic freedom in terms of international human rights law and further assessing the level of protection of that right in various regional contexts, concentrating on the European and African contexts for the moment. This article looks at the legal protection of the right to academic freedom in Europe, i.e. its protection in the legislation of the $28 \mathrm{eu}$ Member States - its factual protection in European countries only to be analysed at a later stage. An overall picture of the situation of the right to academic freedom in Europe, to be sure, would have to take account of the findings with regard to both its legal and factual protection.

The next heading will demonstrate that the two un Human Rights Covenants of 1966 must be considered to safeguard academic freedom inter alia under provisions providing for the right to freedom of expression, the right to education, and respect for 'the freedom indispensable for scientific research.' The Human Rights Committee, the body of independent human rights experts supervising implementation of the International Covenant on Civil and Political Rights, has, in one of its General Comments, stressed that ' unless Covenant rights are already protected by ... domestic laws or practices, States Parties are required on ratification to make such changes to domestic laws and practices as are necessary to ensure theirconformity with the Covenant.' 5 Likewise, the Committee on Economic, Social and Cultural Rights, the body of independent human rights experts supervising implementation of the International Covenant on Economic, Social and Cultural Rights, entertains the view that in realising rights under this Covenant, 'in many instances legislationis highly

5 un, Human Rights Committee, General Comment No. 31, The Nature of the General Legal Obligation Imposed on States Parties to the Covenant, un Doc. ccpr/c/21/Rev.1/Add.13 (2004), para. 13. In fact, Art. 2(2) of the International Covenant on Civil and Political Rights provides that ${ }^{\prime}[\mathrm{w}]$ herenotalready provided forby existinglegislativeorothermeasures, each State Party to the ... Covenant undertakes to take the necessary steps, in accordance with its constitutional processes and with the provisions of the ... Covenant, to adopt such laws or othermeasures as may benecessary to give effect to the rights recognised in the... Covenant' (emphasis added). See also M. Nowak, 'Article 2: Domestic Implementation and Prohibition of Discrimination,' in u.n. Covenant on Civil and Political Rights: ccpr Commentary (N.P. Engel,2nd rev.ed.2005) 27-75, at para.56(59-60)(stating that 'theformulation "legislative or other measures" demonstrates the priority of legislative measures'). 
desirable and in some cases may even be indispensable.' 6 Although the Covenants do not unequivocally make the adoption of legislation mandatory, it is submitted that these Committee statements suggest that - to secure the effective realisation of human rights and to respect fundamental principles of democracy - all salient elements in the definition of the various human rights, the general framework authorising measures aimed at fulfilling them, and possible limitations of those rights be contained in legislation adopted by national parliaments.7 Suchlegislation will increase the visibility of the rights to those entitled to claim them, bind organs of government to respect, protect, and fulfil them, and enable right-holders to enforce them before competent administrative or judicial tribunals. Subordinate legislation as adopted by executive/administrative organs of state may then 'add flesh to the bones' and operationalise the norms contained in primary legislation, but cannot substitute the latter where it is mandatory. Ultimately, the functionaries/organs adopting subordinate legislation are (usually) not directly legitimated by and accountable to the electorate. Protective standards contained in subordinate legislation may, moreover, easily be changed or abrogated again. 8

6 un, Committee on Economic, Social and Cultural Rights, General Comment No. 3, The Nature of States Parties' Obligations (Art. 2, Para. 1, of the Covenant), un Doc. E/1991/23, Annex iii, 86 (1991), para. 3. Art. 2(1) of the International Covenant on Economic, Social and Cultural Rights provides that ' $[\mathrm{e}] \mathrm{ach}$ State Party to the ... Covenant undertakes to take steps ... with a view to achieving progressively the full realisation of the rights recognised in the ... Covenant by all appropriate means, including particularly the adoption oflegislativemeasures' (emphasis added). See also M.C. Craven, The International Covenant on Economic, Social and Cultural Rights: A Perspective on its Development (Clarendon, 1995) 125 (stating that 'it has commonly been asserted that the enactment of legislation is essential to the implementation of economic, social, and cultural rights on the domestic plane'); M. Ssenyonjo, Economic, Social and Cultural Rights in International Law (Hart, 2009) para.

2.14 (55) (remarking that '[1] egislative measures are indispensable in the protection of all human rights, including esc rights').

7 In fact, for limitations of rights, this is confirmed in the various general and specific limitation provisions of the two Covenants.

8 Where essential aspects of the right to academic freedom have been provided for in government regulations or directives, or university statutes (but not in parliamentary legislation), this ordinarily does not, therefore, satisfy (or fully satisfy) requirements for adequate 'legal' protection. The same holds true with regard to collective agreements, which, as such, constitute neither primary nor secondary legislation. Human rights entitlements should not be made contingent on collective bargaining. The assessment undertaken in this article has borne out that a number of the states analysed regulate essential aspects of the right to academic freedom only at the level of secondary legislation (e.g. Denmark, Portugal, Sweden, or the uk), or collective agreements (e.g. Austria, or the Netherlands). 
Accordingly, a state's human rights and he legislation should adequately protect academic freedom and institutional autonomy. As stressed by, for example, the Council of Europe, 'these principles should ... be reaffirmed and guaranteed by law, preferably in the constitution.' 9 In many cases, the absence of such legislation or its failure to provide effective guarantees will constitute the basis for threats to academic freedom and institutional autonomy. Nevertheless, it needs to be pointed out that although the chances of academic freedom enjoying protection are greatly enhanced where an adequate legislative framework is provided for, this will not always be the case. Conversely, ' $[p]$ ractice on the ground often reveals a stronger cultural commitment to freedom than is apparent from perusal of the laws.' 10 It is for this reason that a comprehensive picture of the state of the right to academic freedom will also have to take its protection in practice-as a result of institutional, faculty, and/or departmental regulations, policies, and customs - into account. The factual protection of the right to academic freedom in Europe will, however, only be analysed in subsequent publications, relying primarily on the results of an online survey on academic freedom, open for participation by academic staff in Europe since 2015 until further notice.11

The present assessment of compliance with the criteria of unesco's Recommendation of 1997 - the Recommendation in its Preamble establishing a clear link with un human rights treaty law - will essentially examine whether states have complied with the requirement of adopting legislation protecting the different aspects of the right to academic freedom, as described in the Recommendation, applying the standardsin respect of 'legislation' as just described with regard to the un Covenants.12 Clearly, parliamentary legislation on its own is not enough to realise human rights. Other means (governmental policies, regulations and directives, university statutes, financial resources, infrastructure, personnel, information, etc.) will also have to be relied on. The large-scaleabsence of primary legislation on the topic, as the case of the United Kingdom exemplifies, does not necessarily mean that academic freedom may not, all the same, enjoy protection in practice. However, the chances of it

9 Recom. 1762 (2006) on Academic Freedom and University Autonomy, Parliamentary Assembly, Council of Europe, para. 7.

10 M. Newman, 2007, 'u.k. Lowest on Freedom List,' Times Higher Education, 28 September 2007 (quoting Conor Gearty, (then) Director of the Centre for the Study of Human Rights at the London School of Economics), retrieved 15 May 2016, https://www.timeshigher education.co.uk/news/uk-lowest-on-freedom-list/310603.article.

11 The survey is accessible at https://www.surveymonkey.com/s/AcademicFreedomSurvey.

12 The results of the present assessment of the legal protection of the right to academic freedom in Europe will also be reported on in Vol. 49 (2016) of Vanderbilt Journal of Transnational Law and Vol. 10(2016) of New Zealand Journal of Researchon Europe. 
enjoying such protection are greatly enhanced where an adequate legislative framework is providedfor.

\section{The Right to Academic Freedom under International Human Rights Law}

In his chapter on the right to education in the first major textbook on economic, social and cultural rights in international law, Manfred Nowak in 1995 still had to concede that international law largely neglected the topic of academic freedom and institutional autonomy. 13 This remains true today to the extent that international 'hard' law (treaties legally binding on states parties thereto) is concerned. The right to academic freedom, as such, is not protected in the two un human rights covenants - the International Covenant on Civil andPolitical Rights('iccpr')14 and the International Covenant on Economic, Social and Cultural Rights ('icescr'), 15 both of 1966-orin any other binding instrument of international law at the global or regional level.

Certain provisions of the various human rights treaties applicable globally or regionally may, however, be relied on to protect (particular aspects of) the right to academic freedom.16 Focusing specifically on the un human rights covenants, 17 these include:

- Articles 2(1) and 26iccpr, and Article 2(2) icescr, forbidding discrimination on inter alia the ground of 'political or other opinion' (probably also if the opinion is 'academic' in nature),

13 M. Nowak, 'The Right to Education,' in A. Eide et al. (eds.), Economic, Social and Cultural Rights: A Textbook (1995) 189-211, at 209-210.

14 International Covenant on Civil and Political Rights, opened for signature 16 December 1966, 999 unts 171 (entered into force 23 March 1976) [hereinafter iccpr].

15 International Covenant on Economic, Social and Cultural Rights, opened for signature 16December 1966, 993 unts 3 (entered into force 3 January 1976) [hereinafter icescr].

16 See R. Quinn and J. Levine, 'Intellectual-hrds and Claims for Academic Freedom under Human Rights Law,' International Journal of Human Rights 18(7-8)(2014)898-920, at904, for an overview of relevant provisions in this respect in the major global and regional human rights instruments (including the non-binding Universal Declaration of Human Rights of 1948).

17 Seeibid 902-912, for an analysis of the Covenant provisions referred to in the discussion that follows and their relevance to the right to academic freedom in the light of relevant international legal materials (decisions of international human rights tribunals, General Comments of un human rights treaty monitoring bodies, reports of un Special Rapporteurs, etc.). 
- Article 6 iccpr on the right to life (brutal regimes sometimes executing academics),

- Article 7 iccpr, prohibiting torture or cruel, inhuman or degrading treatment or punishment (clearly including where this takes place in relation to certain academic views or actions),

- Article9iccpr, addressing theright toliberty and security of the person (relevant, for example, where an academic is arbitrarily arrested and detained (and falsely prosecuted) in retaliation for certain academic views or actions),

- Article 12 iccpr on the right to liberty of movement, and Article 13 iccpr on the right of aliens not to be arbitrarily expelled from a state (Articles 12 and 13 guaranteeing the ability of members of the academic community to travel abroad, to return home, and to move freely within a state for the purposes of study, teaching and research), 18

- Article $14 \mathrm{iccpr}$, protecting the right to a fair and public hearing by a competent, independent and impartial tribunal established by law in civil and criminal cases (also cases relating to rights and duties in the sphere of academic freedom),

- Article17iccpr, prohibiting arbitrary orunlawfulinterferencewithprivacy or correspondence (e.g. inspecting or censoring an academic's communication), and unlawful attacks on honour or reputation (e.g. untrue allegations aboutanacademicinretaliationforcertainacademicviewsoractions),

- Article $18 \mathrm{iccpr}$ on the right to freedom of thought, conscience and religion (potentially also encompassing the right of academics to object to teaching or carrying out research on the ground that doing so would be contrary to their conscience, religion or beliefs), 19

- Article 21 iccpr on the right of peaceful assembly (affording protection, for example, to academics organising a conference, in which opinions critical of a government's policies in one area or another are expressed),

- Article 22 iccpr on the right to freedom of association (on which members of the academic community would rely, for instance, to protect their right to form and join trade unions attending to their interests, including those related to academic freedom), 20

18 In this context, see, e.g., K. Beiter, 'The Protection of the Right to Academic Mobility under International Human Rights Law,' in M. Tight and N. Maadad (eds.), Academic Mobility (Emerald, 2014)243-265.

19 It is not entirely clear whether Art. $18 \mathrm{iccpr}$ covers a general right of 'conscientious objection.' See M. Nowak, 'Article 18: Freedom of Thought, Conscience, Religion and Belief,' in u.n. Covenant on Civil and Political Rights: ccpr Commentary (N.P. Engel, 2nd rev. ed. 2005) 406-436, at paras. 10-11 (412-413), paras. 27-32 (421-425).

20 Art. 22 iccpr 'only applies to private associations.' See un, Human Rights Committee, Wallmann v. Austria, Comm. No. 1002/2001, un Doc. ccpr/c/80/d/1002/2001 
- Article 25(c)iccpr, guaranteeing the right of citizens of access to the public service in their country without discrimination, for example, on the ground of 'political or other opinion' (academics in many countries being civil servants), and

- Article 15(1)(c)icescr, protecting the right " $[\mathrm{t}$ ] o benefit from the protection of the moral and material interests resulting from any scientific, literary or artistic production of which [one] is the author,' thus also protecting the right of researchers to claim 'ownership' of and dispose over their scholarly writings (copyright) or inventions (patents). 21

Three Covenant provisions provide protection for the right to academic freedom more comprehensively:

- Article $19 \mathrm{iccpr}$ on the right to freedom of opinion and expression, 22

- Article 15 icescr on cultural rights - notably giving expression, in Paragraph 3 , to the right to respect for 'the freedom indispensable for scientific research,'23 and

- Article 13 icescr on the right to education.

(1 April 2004), para.9.4. It seems thus not to apply to public universities, butto, e.g., trade unions or privateuniversities.

21 In a wider sense, one could also mention Arts. 7, 8, 9, 11, and 12 icescr on the right to just and favourable conditions of work, the right to form and join trade unions, the right to social security, the right to an adequate standard of living, and the right to the highest attainable standard of physical and mental health, respectively. Ultimately, academic freedom can only be enjoyed if the terms and conditions of employment are conducive for effective teaching and research. See unesco Recommendation concerning the Status of Higher-Education Teaching Personnel (1997), para. 40 (calling upon the employers of higher-education teaching personnel to establish terms and conditions of employment of the nature contemplated).

22 Art. 19iccpr needs to be read in conjunction with Art. 20 of the Covenant, which 'limits' the right to freedom of opinion and expression in that it prohibits 'any propaganda for war' and 'any advocacy of national, racial or religious hatred that constitutes incitement to discrimination, hostility or violence.'

23 Where Art. 15(1)(b) icescr recognises the right ' $[t]$ o enjoy the benefits of scientific progress and its applications,' this implies ensuring an environment of free enquiry in all settings where research takes place, making possible such progress in the first place. Art. 15(4) icescr enjoins states parties to 'recognise the benefits to be derived from the encouragement and development of international contacts and co-operation in the scientific and cultural fields.' Again, international contacts and co-operation in the field of science are meaningful in an atmosphere of freedom of enquiry only. 
Some commentators consider the right to freedom of opinion and expression and the right to education to constitute the two essential pillars of the right to academic freedom.24 Others contend that the right to freedom of opinion and expression must be viewed as the fundamental premise of the right to academic freedom. 25 Yet others again hold that, whereas all the various provisions cited above should play a role in protecting relevant aspects of the right to academic freedom, Article 13 icescr on the right to education - in the light of its particular 'design' - constitutes a complete locus for the right to academic freedom: "Article 13 icescr ... constitutes the provision which concurrently assembles all aspects of academic freedom under "a single roof" and whose normative context provides the proper framework for interpretation.'26 There are writers who agree that all the various provisions mentioned should play a role as described, but who maintain that 'Article 13 icescr alone is too weak a basis to support academic freedom.'27

24 See, e.g., Quinn and Levine (n 16) 902-912, specifically 903-905, or B. Rajagopal, 'Academic Freedom as a Human Right: An Internationalist Perspective,' Academe 89(3) (2003) 25-28, at 27-28. Similarly, the Belgian Court of Arbitration, in a decision of 2005, held that the right to academic freedom represented an aspect of freedom of expression (Belgian Constitution, art. 19) and was also a part of the freedom of education (Constitution, art. $24, \S 1$ ). Judgment of 23 November 2005 (No. 167/2005), Cour d'arbitrage, Moniteur Belge, 2 December 2005, para. B.18.1. See M. Pâques, 'Liberté académique et Cour d'Arbitrage,' in Liber amicorum Paul Martens: L'humanisme dans la résolution des conflits: Utopie ou réalité? (Larcier, 2007) 399-418, for a discussion of the decision.

25 See, e.g., K. Appiagyei-Atua, 2014, 'A Theoretical Review of the Origins of Academic Freedom,' University Values, 3 July 2014, retrieved 1 July 2016, https://www.scholarsatrisk.org/ resources/a-theoretical-review-of-the-origins-of-academic-freedom.

26 See K.D. Beiter, 2011, 'The Doctrinal Place of the Right to Academic Freedom under the un Covenants on Human Rights,' University Values (July 2011), https://perma.cc/6APS-UG32; K.D. Beiter, 2013, 'The Doctrinal Place of the Right to Academic Freedom under the un Covenants on Human Rights: A Rejoinder to Antoon de Baets,' University Values (December 2013), https://perma.cc/69V2-SRMJ.

27 See A. de Baets, 2012, 'The Doctrinal Place of the Right to Academic Freedom under the un Covenants on Human Rights: A Rejoinder,' University Values (May 2012), https://perma.cc/M2GF-JSP7; A. de Baets, 2014, 'Some Puzzles of Academic Freedom (Part 1),' University Values, 3 July 2014, retrieved 1 July 2016, https://www.scholarsatrisk.org/resources/some-puzzles-of-academic-freedom-part-1; A. de Baets, 2015, 'Some Puzzles of Academic Freedom (Parts 2 and 3), 'University Values, 9 January 2015, retrieved 1 July 2016, https://www.scholarsatrisk.org/resources/some-puzzles-of-academic -freedom-parts-2-and-3. Problems associated with considering the right to freedom of opinion and expression as the basis of the right to academic freedom are, firstly, the fact that academic freedom entails much more than free speech rights, namely, also rights of 'free action' (e.g. conducting an experiment), and, secondly, the fact that 
There have been noteworthy developments at the international level pertaining to the right to academic freedom. Three of these should briefly be referred to. Firstly, the Committee on Economic, Social andCultural Rights, the body of independent human rights experts supervising implementation of and 'authoritatively interpreting' - the icescr, has, in its General Comment No. 13 on the Right to Education, made some interesting observations regarding 'academic freedom and institutional autonomy.' It states, for example, that it 'has formed the view that the right to education can only be enjoyed if accompanied by the academic freedom of staff and students' and that ' [a]ccordingly, even though the issue is not explicitly mentioned in Article 13, it is appropriate and necessary for the Committee to make some observations about academic freedom.'28

the free speech rights covered are, in fact, special speech rights, circumscribed by the requirements of learning, teaching, and research. See E. Barendt, Academic Freedom and the Law: A Comparative Study (Hart, 2010) 17-21. Regarding the right to respect for 'the freedom indispensable for scientific research' in Art. 15(3) icescr, it should be noted that this is a general right belonging to all persons undertaking scientific research (including, e.g., researchers in private industry or those in public or private specialist institutes). It may be rendered as what is termed 'Wissenschaftsfreiheit' in German constitutional theory, perhaps best translated as 'the right to free scholarship.' The right to academic freedom, on the other hand, accrues to a smaller group of right-holders - namely academic staff in he institutions (or research institutions 'close' to the educational milieu) - but it entails entitlements which are more farreaching in their scope. As has been pointed out by a commentator, '[a]cademic freedom, as it is understood in the United Kingdom and the United States is, in contrast [to 'Wissenschaftsfreiheit'], a special right to which only those engaged in teaching and research at universities and other comparable institutions are entitled.' The freedom of those not working at the latter institutions 'may be narrower than it is for university professors.' The right to academic freedom is, however, also enjoyed by students in he, but the scope of their right is reduced when compared to that of academic staff. See ibid 37-38. For a detailed account of the doctrinal place of the right to academic freedom under the un human rights covenants, see K.D. Beiter, T. Karran and K. Appiagyei-Atua, 'Yearning to Belong: Finding a "Home" for the Right to Academic Freedom in the u.n. Human Rights Covenants,' Intercultural Human Rights Law Review (forthcoming Vol. 11, 2016).

28 un, Committee on Economic, Social and Cultural Rights, General Comment No. 13, The Right to Education (Art. 13), un Doc. e/c.12/1999/10 (1999) [hereinafter General Comment No. 13], para. 38. The Committee then goes on to provide a definition of 'academic freedom,' essentially resembling that cited at $\mathrm{n} 45$ below, and to describe the concept of 'institutional autonomy.' Ibid paras. 39, 40, respectively. General Comments are interpretative tools. The Committee generates themin an attempt to clarify Covenant provisions. Though not legally binding, they do have considerable legal weight. 
Secondly, the European Court of Human Rights, deciding on applications alleging violations of the rights set out in the European Convention on Human Rights('echr') of 1950,29 as amended and supplemented, has, in recentyears, in cases turning on issues of free speech in an academic context, started commenting on certain aspects of the right to academic freedom, resolving these cases on the basis of Article 10 of the Convention, this provision protecting the right to freedom of expression. The first judgment thatex pressly referred toacademic freedom was Sorguç v. Turkey. In this case, the Court 'underline[d] the importance of academic freedom, whichcomprises theacademics' freedomto express freely their opinion about the institution or system in which they work and freedom to distribute knowledge and truth without restriction.' 30

Thirdly, in 1997, unesco - the un specialised agency with primary responsibility for international co-operation in the fields of education, the natural, social, and human sciences, culture, and communication - adopted the Recommendation concerning the Status of Higher-Education Teaching Personnel.31 The Recommendation 'applies to all higher-education teaching personnel.' 32 This means 'all those persons in institutions or programmes of higher education who are engaged to teach and/or to undertake scholarship

29 European Convention for the Protection of Human Rights and Fundamental Freedoms, openedforsignature4November 1950, ets 5 (entered intoforce 3 September 1953) [hereinafter echr].

30 Sorguçv.Turkey, Appl.No.17089/03,ECtHR,2ndSec.,23June2009, para.35. When making its comments on academic freedom, the Court referred to Recom. 1762 (2006) on Academic Freedom and University Autonomy, Parliamentary Assembly, Council of Europe. SeeSorguç, para. 21. It may be mentioned that the Committee of Ministers of the Council ofEuropehasrecently adopted anotherdocument on the subject, Recom.cm/Rec(2012)7 on the Responsibility of Public Authorities for Academic Freedom and Institutional Autonomy. Other cases dealing with academic freedom include Lombardi Vallauriv. Italy, Appl. No. 39128/05, ECtHR, 2nd Sec., 20 October 2009; Sapan v. Turkey, Appl. No. 44102/04, ECtHR, 2nd Sec., 8 June 2010; Aksuv. Turkey, Appl. Nos. 4149/04, 41029/04, ECtHR, Grand Chamber, 15 March 2012; Hasan Yazıcı v. Turkey, Appl. No. 40877/07, ECtHR, 2nd Sec., 15 April 2014; Mustafa Erdoğan v. Turkey, Appl. Nos. 346/04, 39779/04, ECtHR, 2nd Sec., 27 May 2014. In the latter case, see also the interesting Joint Concurring Opinion of Judges Sajó, Vučinić and Kūris, developing criteria for the protection of 'extramural' speech of academics. All judgments are available in the Court's online hudoc database at http://www.echr.coe.int/Pages/home.aspx?p=home\&c=.

31 General Conference (unesco), Recommendation concerning the Status of HigherEducation Teaching Personnel, unesco Doc. 29 C/Res. 11 (1997) [hereinafter (the) unesco Recommendation].

Ibid para. 2 . 
and/ortoundertakeresearchand/ortoprovideeducationalservicestostudents or to the community at large.' 33 The Recommendation addresses aspects of academic freedomin several of its provisions. These provisions will be used as the basis for assessing compliance with the right to academic freedom in Europe in the discussion that follows; on the one hand, because the provisions constitute the mostcurrent expression of agreed international standards on the topic, on the other, because they must be considered to 'give content' to un human rights law as expressed in the un human rights covenants referred to above. 34

\section{4 unesco's Recommendation concerning the Status of Higher- Education Teaching Personnel of 1997 and Its Provisions on Academic Freedom}

unesco's Recommendation concerning the Status of Higher-Education Teaching Personnel of 1997 deals with a multitude of issues in seeking to safeguard the rights and duties of higher-education teaching personnel. The following topics are covered:

- guiding principles (regarding he and teaching personnel in he) (part iii, paras. 3-9);

- educational objectives and policies (in the sphere of he) (part iv, paras. 10-16);

33 Ibid para. 1(f). Predating this Recommendation is another Recommendation adopted by unesco: the Recommendation on the Status of Scientific Researchers of 1974. This instrument, applicable, as it is, to scientific researchers, and protecting, amongst others, their freedom of research, covers a wider group of researchers than only those in he. The Recommendation defines 'scientific researchers' as 'those persons responsible for investigating a specific domain in science or technology' - 'sciences' meaning the sciences concerned with social facts and phenomena, to the extent that theoretical elements are capable of being validated - irrespective of the type of establishment in which such researchers work, the motivation underlying the research, and the kind of application to which it relates most immediately. Ibid para. 1.

34 In its Preamble, the Recommendation thus establishes a clear link with un human rights treaty law, referring to Art. 13(2)(c) icescr on the right to higher education. See further Arts. 18-23 icescr, articulating the responsibility of the un specialised agencies, such as unesco, to concretise Covenant provisions by adopting relevant conventions and recommendations. See K.D. Beiter, The Protection of the Right to Education by International Law: Including a Systematic Analysis of Article 13 of the International Covenant on Economic, Social and Cultural Rights (Martinus Nijhoff, 2006) 229-232, 280. 
- institutional rights, duties, and responsibilities (institutional autonomy and institutional accountability) (part v, paras. 17-24);

- rights and freedoms of higher-education teaching personnel (individual rights andfreedoms (civil rights, academic freedom, publication rights, and the international exchange of information), and self-governance and collegiality) (part vi, paras. 25-32);

- duties and responsibilities of higher-education teaching personnel (part vii, paras. 33-36);

- preparation for the profession (part viii, paras.37-39);

- terms and conditions of employment (entry into the academic profession; security of employment; appraisal; discipline and dismissal; negotiation of terms and conditions of employment; salaries, workload, social security benefits, health and safety; study and research leave and annual holidays; terms and conditions of employment of women, disabled and part-time higher-education teaching personnel) (part ix, paras. 40-72);

- utilisation and implementation (part x, paras. 73-76); and

- final provision (providing that the Recommendation may not be invoked to diminish a more favourable status already granted to higher-education teaching personnel) (part xi, para. 77).

The Recommendation is more than a mere code regulating the profession of he teaching. Apart from improving the professional, material, and social position of higher-education teaching personnel, it is also, as a result of improvements in that position, aimed at enhancing the quality of the he system.35 It is appreciated that the goals of he, such as pursuit, advancement, and transfer of knowledge, satisfying students' higher educational needs, and securing a well-qualified work force, can only be reached if there exists a he system of high quality.36 Recognising the decisive role of higher education teaching personnel towards reaching the stated goals, such personnel '[must] enjoy the status commensurate with this role.' 37 Although the Recommendation is not as such 'aninternational instrument on academic freedom,' guaranteeing academic freedom in he is a fundamental concern of the document. Already the Preamble to the Recommendation, in Recitals 8 and 9,

[e]xpress[es] concern regarding the vulnerability of the academic community to untoward political pressures which could undermine

$35 \quad$ See ibid 280.

36 unesco Recommendation, Preamble, Recitals 3, 4.

37 Ibid, Preamble, Recitals 5, 10. 
academic freedom, [and] [c]onsider [s] that the right to education, teaching and research can only be fully enjoyed in an atmosphere of academic freedom and autonomy for institutions of higher education and that the open communication of findings, hypotheses and opinions lies at the very heart of higher education and provides the strongest guarantee of the accuracy and objectivity of scholarship and research[,]

thus recognising the importance of ensuring academic freedom and institutional autonomy if he is to achieve the objectives identified above. 38 Various provisions of the Recommendation focus on aspects of academic freedom. The provisions - apart from addressing freedom of teaching and freedom in carrying out research - cover at least three additional aspects, namely, selfgovernance in he by the academic community, employment security (including 'tenure'), and the autonomy of institutions of he. These various rights are, however, to be interpreted in the light of special duties and responsibilities for staff and students, and the fact that a proper balance between the level of autonomy enjoyed by he institutions and their systems of accountability should be ensured. All the above elements taken together make up what may be termed 'the right to academic freedom.' 39

38 While academic freedom is thus to ensure that 'proper' learning, teaching and research can take place, at a more abstract level, the justification for safeguarding academic freedom may be stated to be two-fold: firstly, ensuring that academics can engage in a free search for the truth for the benefit of society as a whole, and, secondly, advancing 'ethical individualism' (values of intellectual independence). See R. Dworkin, 'We Need a New Interpretation of Academic Freedom,' in L. Menand (ed.), The Future of Academic Free$\operatorname{dom}$ (1996) 181-198, at 185-189 (referring to the instrumental and ethical ground of protection in this context, respectively). On yet another level, the purpose of academic freedom may be stated to be to promote human dignity, i.e. the human dignity of academics as members of the academic profession, and the human dignity of all those whobenefit from academic freedom and its 'production' of truth and progress. Generally on the rationale for the protection of academic freedom as a human right, see Beiter et al. (n 27).

39 See, e.g., T. Karran, 'Academic Freedom in Europe: Time for a Magna Charta?,' Higher Education Policy 22(2) (2009) 163-189, or J. Vrielink et al., Academic Freedom as a Fundamental Right (League of European Research Universities, Advice Paper No. 6, December 2010), retrieved 15 May 2016, http://www.leru.org/files/publications/AP6_Academic_ final_Jan_2011.pdf, for a discussion of the various elements (rights, duties, responsibilities) of the right to academic freedom. See also General Comment No. 13 (n 28) paras. 38-40. The unesco Recommendation thus contains provisions on 'Institutional autonomy'(v.a.), paras. 17-21, 'Institutional accountability' (v.b.), paras. 22-24, 'Individual rights and freedoms: civil rights, academic freedom, publication rights, and the international exchange of information' (vi.a.), paras. 25-30, 'Self-governance and collegiality' (vi.b.), 
unesco's Recommendations are not legally binding. However, it would be wrong to hold them to be legally irrelevant. They 'bind' as soft-law. Appreciating that Recommendations have been adopted by the General Conference of unesco, they must be considered to reflect an international consensus on the specific subject matter dealt with. Recommendations 'have a normative character in their intent and effects and the States concerned regard them as political or moral commitments.' 40 Note should be taken of Paragraph 74 of the Recommendation, which calls upon 'Member States and higher education institutions [to] take all feasible steps to apply the provisions [of the Recommendation] to give effect, within their respective territories, to the principles set forth in [the] Recommendation.' Moreover, under unesco's Constitution, unesco's members are obliged to submit the various recommendations adopted to their competent authorities so that the latter may take cognisance of their provisions, and further to report on the measures taken towards and the progress made in implementing recommendations.41 As the Recommendation deals with international labour and international education law, supervision of its implementation by unesco Member States is entrusted to a Joint ilo/unesco Committee of Experts on the Application of the Recommendations concerning Teaching Personnel ('ceart').42 The Committee is composed of twelve independent experts - six appointed by unesco, six by the ilo. It holds sessions every three years. The Committee essentially performs two tasks: It examines relevant data, including the reports referred to, to adjudge application of the Recommendation, and itexamines allegations received from teachers' organisations on the non-observance of provisions of the Recommendation in Member States.43

paras. 31-32, 'Duties and responsibilities of higher-education teaching personnel' (vii), paras. 33-36, and 'Security of employment' (ix.b.), paras. 45-46.

40 Y. Daudet and K. Singh, The Right to Education: An Analysis of unesco 's Standard-Setting Instruments (unesco, 2001) 45, retrieved 15 May 2016, http://unesdoc.unesco.org/ images/0012/001238/123817e.pdf.

41 Constitution of the United Nations Educational, Scientific and Cultural Organisation, opened for signature 16 November 1945, 4 unts 275 (entered into force 4 November 1946), art. iv(4),(6), respectively.

42 Already in 1966, unesco adopted a Recommendation concerning the Status of Teachers, applicable to teachers in schools from the pre-primary up to completion of the secondary level of education.

43 For more information on the supervision of the relevant Recommendations, see Beiter (n 34) 282-284; and ceart's latest sessional reports, e.g., Rep., 10th Session, 28 September-2 October 2009, ilo/unesco Doc. ceart/10/2009; Rep., 11th Session, 8-12 October2012, ilo/unesco Doc. ceart/11/2012/9; Rep., 12th Session, 20-24 April2015, ilo/unesco Doc. ceart/12/2015/14. 
As alluded to above, the various provisions of the Recommendation addressing aspects of academic freedom may broadly be divided into four groups:44

1. Provisions on individual rights and freedoms in Paragraphs 25 to 30;

2. Provisions on institutional autonomy in Paragraphs 17 to 21;

3. Provisions on self-governance and collegiality in Paragraphs 31 and 32; and

4. Provisions on security of employment, including 'tenure or itsfunctional equivalent, where applicable,' in Paragraphs 45 and 46.

A few words should be said with regard to each of the aspects protected. Firstly, regarding provisions on individual rights and freedoms, these envisage academics enjoying 'internationally recognised civil, political, social and cultural rights applicable to all citizens' (Para. 26) and 'the principle of academic freedom' (Para. 27). Regarding the former rights, the Recommendation, in fact, refers to many of the rights mentioned under the previous heading, such as freedom of thought, conscience, religion, expression, assembly, and association, freedom and security of the person, freedom of movement, etc. The principle of academic freedom, on the other hand, implicates

the right [of higher-education teaching personnel], without constriction by prescribed doctrine, to freedom of teaching and discussion, freedom in carrying out research and disseminating and publishing the results thereof, freedom to express freely their opinion about the institution or system in which they work, freedom from institutional censorship and freedomtoparticipateinprofessionalor representativeacademic bodies. All higher-education teaching personnel should have the right to fulfil their functions without discrimination of any kind and without fear of repression by the state or any other source. 45

Scholars have been described as 'dangerous' minds.46 As one of the Recommendation's guiding principles articulates, '[i]nstitutions of higher education ... are communities of scholars preserving, disseminating and expressing freely

44 See Karran (n 2) 195-196.

45 See, e.g., Karran (n 39) 170-175, A. Prüm and R. Ergec, 'La liberté académique,' Revue du droitpublic et de la science politique en France et àl'étranger No. 1 (2010) 1-28, at 13-17, or Vrielink et al. (n 39) paras. 27-59 (9-18), on 'the principle of academic freedom' (in effect, academic freedom as an individual right) as an aspect of the right to academic freedom.

46 R. Quinn, 'Defending "Dangerous" Minds: Reflections on the Work of the Scholars at Risk Network,' Items \& Issues 5(1-2) (2004) 1-5, at 1. 
their opinions on traditional knowledge and culture, and pursuing new knowledge without constriction by prescribed doctrines.' 47 Challenging orthodox ideasandbeliefs and creating newknowledgemeanthat, 'becauseof thenature of their work, academics aremorenaturally ledin toconflict with governments and other seats of authority.' 48 For this reason, advances in he depend not only on infrastructure and resources, but need to be underpinned by academic freedom.49 Higher-education teaching personnel accordingly 'have a right to carry out research work without any interference, or any suppression, ... subject to ... recognised professional principles of intellectual rigour, scientific enquiry and research ethics.' They 'should also have the right to publish and communicate the conclusions of the research of which they are authors or co-authors.' 50 They further 'have the right to teach without any interference, subject to accepted professional principles,' 'should not be forced to instruct against their own best knowledge andconscience,' and 'should play a significantrolein determining the curriculum.' 51 Academic freedom is subject to important duties and responsibilities, as described in Paragraphs 33 to 36 . Thereis, forexample, aduty of higher-education teaching personnel 'to teach students effectively' as there is aduty 'tobase... research and scholarshipon anhonestsearchforknowledge with due respect for evidence, impartial reasoning and honesty in reporting.' 52

Secondly, the Recommendation's provisions on institutional autonomy oblige unesco Member States 'to protect higher education institutions from threats to their autonomy coming from any source.' 53 Threats need not, therefore, necessarily emanate from the state, but they may also, forexample, originate with private actors such as private companiescommissioning research.In terms of Paragraph 17 of the Recommendation, institutional autonomy means

that degree of self-governance necessary for effective decision-making by institutions of higher education regarding their academic work, standards, management and related activities consistent with systems of

47 unesco Recommendation, para. 4.

$48 \quad$ Karran (n 2) 191.

49 See unesco Recommendation, para. 5 (also one of the Recommendation's guiding principles).

$50 \quad$ Ibid para. 29.

51 Ibid para. 28.

52 Ibid para. 34(a), (c), respectively. See, e.g., D. Kennedy,Academic Duty (Harvard up, 1997), on academic duties.

53 unesco Recommendation, para. 19. See, e.g., Prüm and Ergec (n 45) 18-21, or Vrielink et al. (n 39) paras. 60-76 (18-22), on institutional autonomy as an aspect of the right to academic freedom. 
public accountability, especially in respect of funding provided by the state, and respect for academic freedom and human rights.

It is important to appreciate that there is no automatic link between institutional autonomy and individual academic freedom: '[A] highly autonomous institution may offerits members only a limited degree of academic freedom.' In fact, '[a]s certain responsibilities move gradually from public authorities to higher education institutions, academic freedom could be endangered.' 54 It is for this reason that the unesco Recommendation stresses that a proper interpretation of institutional autonomy needs to render that term as autonomy 'consistent with ... respect for academic freedom.' As it were, the Recommendation understands autonomy to be 'the institutional form of academic freedom.' 55 Autonomy should further 'not be used by higher education institutions as a pretext to limit the rights of higher-education teaching personnel provided for in [the] Recommendation.' 56 Autonomy must go hand in hand with public accountability. The Recommendation requires 'Member States and higher education institutions [to] ensure a proper balance between the level of autonomy enjoyed by higher education institutions and their systems of accountability.' 57 he institutions are thus accountable for a commitment to quality in teaching and research, ensuring high quality education, the creation of codes of ethics to guide teaching and research, honest and open accounting, and an efficient use of resources.58 They are also accountable for 'assistance in the fulfilment of economic, social, cultural and political rights,' 'ensuring that they address themselves to the contemporary problems facing society,' and 'play[ing] an important role in enhancing the labour market opportunities of theirgraduates.' 59 Very importantly, he institutions are accountable for the 'effective support of academic freedom and fundamental human rights.' 60

54 P.Zgaga, 'Reconsidering University Autonomy and Governance: From Academic Freedom to Institutional Autonomy,' in H.G. Schuetze et al. (eds.), University Governance and Reform: Policy, Fads, and Experience in International Perspective (Palgrave Macmillan, 2012) 11-22, at 19.

55 unesco Recommendation, para. 18. See W. Berka, 'Die Quadratur des Kreises: Universitätsautonomie und Wissenschaftsfreiheit,' Zeitschrift für Hochschulrecht, Hochschulmanagement und Hochschulpolitik 7(2) (2008) 37-48, on the general difficulty of reconciling institutional autonomy and academic freedom, emphasising the Austrian context.

56 unesco Recommendation, para. 20.

57 Ibid para. 22, caput.

58 See ibid para. 22(b), (d), (k), (i), (j), respectively.

59 Ibid para. 22(1),(m).

60 Ibid para. 22(c). 
Thirdly, unesco's Recommendation contains provisions on self-governance, i.e. the participation of higher-education teaching personnel in the governance of institutions of he, and on principles of collegiality, in Paragraphs 31 and 32, respectively. Academics pursue their scholarly activities within an institutional setting. The institutions in which they work will have to organise themselves - their structures, governance and activities - in one way or another. Respect for academic freedom implies that the organisation is such as will ensure that free teaching and research can take place in the institutions. This will be the case if the specific way a he institution organises itself is of a nature as will guarantee that decisions taken by persons/organs will be 'in the best interest of science and scholarship' ('wissenschaftsadäquat'). This, in turn, will only be the case if academics, as those entitled to claim academic freedom, can sufficiently participate in the taking of these decisions. Clearly, by virtue of their training and competence, their long-lasting professional occupation with certain subject matter as well as the fact that such decisions will have a long-term effect on their scholarly work, academics are best qualified to ensure that decisions taken are 'in the best interest of science and scholarship' and support academic freedom.61 Self-governance under unesco's Recommendation entails that higher-education teaching personnel

should have the right and opportunity, without discrimination of any kind, according to their abilities, to take part in the governing bodies and to criticise the functioning of higher education institutions, including their own, while respecting the right of other sections of the academic community to participate, and they should also have the right to elect a

61 See the Hamburgisches Hochschulgesetz case, Judgment of 20 July 2010, Bundesverfassungsgericht der brd[Federal Constitutional Court of Germany], BVerfGE 127, 87, at paras. 88-95 (114-118), for this line of reasoning in justification of the right of self-governance. The court, relying on important earlier case law, observed that the goal here had to be to ensure that relevant decisions were 'in the best interest of science and scholarship' ('wissenschaftsadäquat'). See R. Müller-Terpitz, 'Neue Leistungsstrukturen als Gefährdung derWissenschaftsfreiheit?,'Wissenschaftsrecht44(3)(2011)236-263, for a discussion of when governance arrangements of he institutions may be considered to be consistent with academic freedom. Although the article deals with the situation in Germany, most of its statements are equally applicable in a more general sense. See, e.g., Karran (n 39) 175-176, Prüm and Ergec (n 45) 21-25, or Vrielink et al. (n 39) paras. 65-66 (19-20), on selfgovernance as an aspect of the right to academic freedom. 
majority of representatives to academic bodies within the higher education institution.62

The closely related principles of collegiality that are to apply in terms of the Recommendation

include academicfreedom, shared responsibility, the policy of participation of all concerned in internal decision-making structures and practices, and the development of consultative mechanisms.

It is pointed out that

[c]ollegial decision-making should encompass decisions regarding the administration and determination of policies of higher education, curricula, research, extension work, the allocation of resources and otherrelated activities, in order to improve academic excellence and quality for the benefit of society at large. 63

If it has been explained above that institutional autonomy should be interpreted so as to be consistent with academic freedom, it should be added that '[s] elf-governance, collegiality and appropriate academic leadership are essential components of meaningful autonomy for institutions of higher education.' 64 Consequently, a he institution that enjoys substantial autonomy, but in which higher-education teaching personnel cannot sufficientlyparticipate in the taking of decisions having a bearing - whether in a wider or a narrower sense-on science and scholarship fails to comply with the requirement of institutional autonomy as understood by the Recommendation.

Fourthly and finally, unesco's Recommendation, in Paragraphs 45 and 46, emphasises that higher-education teaching personnel should enjoy security of employment, including 'tenure or its functional equivalent, where applicable.' In the Recommendation's perception, tenure (or its equivalent) 'constitutes one of the major procedural safeguards of academic freedom and against arbitrary decisions.' 65 Tenure may seem anomalous in the modern working

62 unesco Recommendation, para. 31.

63 Ibid para.32.

64 Ibidpara.21.

65 Ibid para. 45. Cf. M. Rendel, 'Human Rights and Academic Freedom,' in M. Tight (ed.), Academic Freedom and Responsibility (Society for Research into Higher Education \& Open up, 1988) 74-87, at 87 (explaining that tenure also protects institutional autonomy: 'Tenure is 
environment, characterised by high employment mobility, regular retraining for new jobs, previous ones becoming obsolete, fixed-term contracts being awarded in respect of projects rather than 'life-time jobs,' and contracts of service that may easily be terminated on operational grounds. It is important to remember, however, that tenure is not granted to academics as 'a mere proprietary benefit,' as it were. In the first paragraph of its caput, the 1940 Statement of Principles on Academic Freedom and Tenure, adopted by the American Association of University Professors and the Association of American Colleges (today the Association of American Colleges and Universities), underlines that '[i]nstitutions of higher education are conducted for the common good and not to further the interest of either the individual teacher or the institution as a whole,' '[t]he common good depend[ing] upon the free search for truth and its free exposition.' Likewise, the us Supreme Court, in its landmark decision in Keyishian v. Board of Regents, solemnly declared that 'Our Nation is deeply committed to safeguarding academic freedom, which is of transcendental value to all of us, and not merely to the teachers concerned.' 66 Hence, tenure - and academic freedom, which it protects by ensuring that academics can engage in a free search for the truth without having to fear losing their jobs, for example, because of the viewsexpressed67-are closely linked to scholars' responsibility for promoting the interests of society as a whole through their teaching and research.68 Paragraph 46 of unesco's Recommendation envisages tenure (or its equivalent) to be granted 'after a reasonable period of probation'69-'following rigorous evaluation' - 'tothose whomeet stated objective criteriain teaching ... [and] research to the satisfaction of an academic body.' Tenure (or its equivalent) entails 'continuing employment' and potential

important because it can defend not only the individual academic but also the institution from ideological and managerial pressures, by helping them to continue to teach unfashionable or unpopular subjects, to research inconvenient topics and to provide more centres of initiative than hierarchical management can.'). See, e.g., Karran (n 39) 177-185, or Prüm and Ergec (n 45) 26, on 'tenure' as an aspect of the right to academic freedom.

66385 us 589, at 603 (1967).

67 See C. Russell, Academic Freedom (Routledge, 1993) 23 (stating that " $\mathrm{t}$ ] he point is not that academics may not be dismissed for their opinions: it is that they need freedom fromfear thatthey might be sodismissed. Without it, they cannotbe counted on todotheir work well.').

68 On the justification for safeguarding academic freedom and tenure, see $n 38$ above.

69 Paragraph 42 of the unesco Recommendation stipulates that the duration of probation should be known in advance and conditions for its satisfactory completion strictly related to professional competence. Reasons should further be provided should a candidate fail to complete the probation satisfactorily. There should also be a right to appeal. 
dismissal 'on professional grounds and in accordance with due process' only. The Recommendation allows release 'for bona fide financial reasons, provided that all the financial accounts are open to public inspection, that the institution has taken all reasonable alternative steps to prevent termination of employment, and that there are legal safeguards against bias in any termination of employment procedure.' Moreover, tenure (or its equivalent) 'should be safeguarded as far as possible even when changes in the organisation of or within a higher education institution or system are made.'

\section{Indicators and Rankings: Some Observations}

Relying on a set of specific indicators, the present article assesses the extent to which the constitutions, laws on he, and other relevant legislation of eu states implement the right to academic freedom, and ranks states in accordance with 'their performance.' It has been argued that using indicators 'to measure the world' is tantamount to quietly exercising power.70 Selecting indicators, weighting them, and relying on the data they reflect are all political processes. Indicators constitute 'a form of knowledge and a technology for governance.' They 'influence governance when they form the basis for political decision making, public awareness, and the terms in which problems are conceptualized and solutions imagined.' There is a linkage between indicators and power. 71 This cannot be disputed. Indicators are used to assess accountability. It has been critically remarked that the growing use of quantitative indicators to measure accountability has transformed the meaning of accountability to mean 'auditability,' in a way 'focusing on indicators rather than on the qualities that the measures are designed to evaluate.' Such auditing, so the argument goes, may have a contrary effect to that intended, consequences not beneficial to accountability. Where doctors' performance, for example, is publicly ranked utilising criteria including mortality rates, the consequence may be that doctors prefer not to intervene in critically ill patients so as not to risk tainting their scorecards. It is argued, as it were, that public measures may be used to

70 S. Engle Merry et al. (eds.), The Quiet Power of Indicators: Measuring Governance, Corruption, and Rule of Law (Cambridge up, 2015). Produced in the same context, see also K.E. Davisetal.(eds.), Governance byIndicators: GlobalPowerthrough Quantificationand Rankings (oup, 2012).

71 K.E. Davis et al., 'Introduction - The Local-Global Life of Indicators: Law, Power, and Resistance,' in Engle Merry et al. (2015) (n 70) 1-25, at 1-2. 
recreate social worlds. 72 This is also undisputed. The assessment of academic freedom undertaken here and the indicators applied to this effect are clearly to constitute 'a basis for political decision-making,' decision-making supportive of the right to academic freedom and resulting in robust legal protection for that right. Care will be taken tonot merely 'audit' state performance, but to approximate a genuine qualitative assessment of state compliance with relevant criteria of the right to academic freedom. 73

As has been pointed out above, the right to academic freedom may arguably be considered rooted in the right to education. A former un Special Rapporteur on the right to education has commented that

[she] feels that the vast amounts of data which are being internationally generated within the field of education do not conform to the human rights approach to education, and a conceptual challenge remains for the human rights community to design indicators that would capture the essence of the right to education and human rights in education.74

The indicators chosen here will purposively not measure whether he reforms in the countries concerned comply with requirements of economic or managerial efficiency, as such criteria are irrelevant in - and in any event subordinate to - a human rights approach as binding on all the states considered in this assessment. The effort here will be to rely on human rights indicators indicators operationalising the requirements of the right to academic freedom as protected under international human rights law.75 Apart from one

72 W. Nelson Espeland and M. Sauder, 'Rankings and Reactivity: How Public Measures Recreate Social Worlds,' American Journal of Sociology 113(1) (July 2007) 1-40, specifically at 2.

73 See also A. Rosga and M.L. Satterthwaie, 'The Trust in Indicators: Measuring Human Rights,' Berkeley Journal of International Law 27(2) (2009) 253-315, at 315 (indicators 'are tools like any other. All tools can be misused .... The key lies in knowing where - and how - human judgment and political contestation should enter.').

74 K. Tomaševski, Progress Report of the Special Rapporteur on the Right to Education, Submitted in Accordance with Commission on Human Rights Resolution 1999/25, un Doc. E/cn.4/2000/6 (1 February 2000), para. 73.

75 A human rights indicator may be defined as 'specific information on the state or condition of an object, event, activity or outcome that can be related to human rights norms and standards; that addresses and reflects human rights principles and concerns; and that can be used to assess and monitor the promotion and implementation of human rights.' See Office of the un High Commissioner for Human Rights (ohchr), Human Rights Indicators: A Guide to Measurement and Implementation (hr/pub/12/5) (un, 2012) 16. Guidance in designing human rights indicators may usefully be sought in the former guide 
indicator measuring 'the percentage of academic staff with permanent contracts of service or on a tenure-track' (Indicator E.1.2.), all other indicators have a clear qualitative focus, i.e. they measure 'information beyond statistics.' 76 They assess whether the law of a country contains provisions on this or that aspect of academic freedom, and the degree to which these provisions may be considered compliant with accepted criteria of academic freedom as a human right. The qualitative dimension is also reflected in the fact that indicators will be weighted in accordance with their relative importance. The indicators applied are 'fact-based' rather than 'judgement-based.' They assess 'facts ... that can ... be directly observed or verified' rather than 'perceptions, opinions, assessment or judgements expressed by individuals.'77 Although '[e]lements of subjectivity in the ... category of objective indicators cannot be fully excluded or isolated,' 'the use of transparent, specific and universally recognized definitions for particular ... facts ... contributes, in a general sense, to greater objectivity when identifying and designing any type of indicator.' 78 The indicators on academic freedom utilised here rely on extensive definitions as to the specific attributes that should be reflected by legal provisions on academic freedom.79

and further in the following publications: un Department of Peacekeeping Operations and ohchr, The United Nations Rule of Law Indicators: Implementation Guide and Project Tools (un, 2011); ohchr, Manual on Human Rights Monitoring (hr/p/pt/7/Rev.1) (un, 2011); S. McInerney-Lankford and H.-O. Sano, Human Rights Indicators in Development: An Introduction (World Bank Study, World Bank, 2010).

76 Whereas a quantitative indicator is 'any kind of indicator that is expressed primarily in quantitative form, such as numbers, percentages or indices,' a qualitative indicator measures 'information beyond statistics that is qualitative in nature.' See ohchr (2012) 16-17.

77 Ibid 17. On this distinction between fact-based and judgement-based indicators, see ibid $17-19$.

78 Ibid 17.

79 For reasons of space, the definitions of the close to 40 indicators chosen cannot be produced below. An example will have to suffice. Indicator D.2.2.2. on Determining the Rector [1-0,5-0] has been defined as follows:

11 . Academic staff exercise 'control' over who is chosen as the rector, the state is not required to appoint the rector or to confirm the chosen candidate, and the provisions on determining the rector comply also in all other respects with accepted requirements of academic self-governance (e.g. democratic principles) (= full compliance).

0,5 2. (a) As in 1., except that academic staff do not exercise 'control' over who is chosen as the rector, but they have a graded, but clear right of participating in the selection procedures, alternatively, (b) as in 1., except that the state is required to appoint the rector or to confirm the chosen candidate, alternatively, (c) as in 1., except that, in the light of accepted requirements of academic self-governance 
To the extent that a subjective assessment remains to be provided, this may, in all modesty, be stated to be an expert assessment. It is sometimes asserted that it is not feasible to measure human rights compliance because human rights relate to qualitative aspects of life, which are not amenable to being captured by indicators. It needs to be appreciated, however, that indicators 'are tools that add value to assessments with a strong qualitative dimension; they do not replace them.' 80 Apart from the fact that, as pointed out, the indicators chosen in this assessment do have aclearqualitative focus, independent, holistic, nonindicator-based qualitative assessments of the state of the legal protection of theright toacademic freedomineachEuropean state remain necessary, but are rather the responsibility of experts in the various states. While the present assessment can thus provide an indication of the status quo in law, a comprehensive picture would have to be obtained by considering the drafting history of legislative provisions, governmental policy documents explaining the reasons for adopting certain legislative provisions, interpretations of legislative provisions by courts of law, etc. This, however, is beyond the purview of this article.

In the light of the complexity of human rights, is it legitimate to use indicators to rank countries according to their human rights performance? Concurring with the view expressed by the Office of the un High Commission for Human Rights, it is submitted that this may be legitimate in certain cases:

[I] dentified indicators can be used to undertake some comparison across countries, but such use is bound to be confined to comparing performance on a few specific human rights standards at a time, such as the right to education or the right to life or aspects of these rights ..., and not the entire gamut of human rights. 81

(e.g. democratic principles), the provisions on determining the rector reveal certain deficiencies, alternatively, (d) all cases, where more than one of (a), (b), and (c) would be applicable, but the cumulative effect of the deficiencies does not yet warrant describing the overall situation as one of non-compliance (= partial compliance).

0 3. (a) Academic staff neither exercise 'control' over who is chosen as the rector, nor do they have a graded, but clear right of participating in the selection procedures (additionally, 2. (b) and/or (c) could be applicable), alternatively, (b) all cases, where more than one of 2. (a), (b), and (c) would be applicable, and the cumulative effect of the deficiencies warrants describing the overall situation as one of non-compliance, alternatively, (c) all cases, where, in the light of accepted requirements of academic self-governance, the provisions on determining the rector reveal major deficiencies (= non-compliance).

81 Ibid 30. 
The ranking undertaken here focuses on a clearly outlined aspect of human rights law, the right to academic freedom, focusing, moreover, only on the legal protection of that right. How should human rights indicators be conceptualised? First of all, the attributes of the relevant human right need to be identified, 82 before devising structural, process, and outcome indicators to measure these. Regarding the former, attributes are to be identified by (a) exhaustively reading the relevant human rights standard so as not to overlook parts thereof, (b) selecting attributes that collectively reflect the essence of a right's normative content, and articulating these in a way as to facilitate the subsequent identification of adequate indicators, and (c) ensuring that the attributes selected are mutually exclusive. 83 Presently, an exhaustive reading of the unesco Recommendation of 1997 and other relevant international human rights law (see Parts 3, 4, and 6) has been undertaken to identify relevant attributes of the right to academic freedom. Categorising these into different groups corresponding to the major elements of the right to academic freedom as reflected in the unesco Recommendation (i.e. the principle of academic freedom, institutional autonomy, academic self-governance, and employment security (including 'tenure')), and making sure that each of these groups covers all salient aspects of the right within that group, help ensuring that the essence of the normative content of the right to academic freedom is adequately captured, and that as far as possible attributes do not overlap. Regarding the subsequent construction of indicators, it needs to be kept in mind that an overall assessment of the state of realisation of a human right should rely on structural, process, and outcome indicators. 84 Whereas structural indicators assess commitment to implementing standards (the ratification and adoption of legal instruments), 85 process indicators assess specific measures taken to implement commitments (budget allocations, policies adopted, awareness-raising activities, etc.),86 and outcome indicators 'capture individual and collective attainments that reflect the state of enjoyment of human rights in a given context' (e.g. attainment levels for certain population groups or reported cases of violations, etc.). 87 The present analysis focuses on structural indicators. Process and outcomeindicators will be used when assessing the factual protection

82 The ohchr states in this regard that indicators must be 'anchored' in human rights standards (ibid 30), describing the procedure at 30-33.

83 See ibid31.

84 Seeibid33-38.

85 Seeibid34-35.

86 Seeibid36-37.

87 Seeibid37-38. 
of the right to academic freedom by way of an online survey of academic staff at a future point. Finally, it has been stated that 'there is a need to combine different sources and data-generating mechanisms to encourage a more comprehensive and credible assessment of any human rights situation.' 88 Potential sources are events-based data on human rights violations, socio-economic data(administrative or researcher-gathered), perception and opinion surveys, and data based on expert judgements.89 This assessment relies on legislative information. The onlinesurvey alluded to willgatherevents-based data on violations of the right to academic freedom, and also data on perceptions of and opinions on academic freedom among academics.

\section{DevelopingaStandardScorecard 'toMeasure' the LegalProtection of the Right to Academic Freedom in Europe}

There is no reason why the four parameters of the right to academic freedom, as defined in Part 4 above, should not, in an assessment of the legal protection of the right to academic freedom in Europe, be given equal weight. Academic freedom (individual freedom to teach and carry out research) is as important as are each of institutional autonomy, self-governance, and tenure to buttress academic freedom.90 The four parameters will therefore be accorded equal weight in the standard scorecard used 'to measure' the right to academic freedom in each country examined -20 percent each. The final 20 percent to arrive at an overall percentage score for each country assessed is accorded to the parameter 'ratification of international agreements and constitutional protection.' Altogether, 37 specific indicators measuring state compliance, concretising the main parameters, have been identified. As underlined, these are human rights indicators. A numeric value has been assigned to each indicator, mirroring its relative weight as adjudged in terms of international human rights law. When adding up the scores of states in respect of each of these values, it is possible to rank states for each of the five parameters, but also overall. To eliminate subjectivity in 'giving marks,' the approach with regard to each

$88 \quad$ Ibid 51.

89 See ibid 52-68.

90 See Karran (n 1) 291-292 (holding that 'in the absence of data as to the relative importance of various parameters of academic freedom, [it may be] assume[d] that all such parameters are equally important'). 
indicator - following Karran's earlier method in this respect - has been to determine whether there is 'full compliance' (full mark), 'qualified compliance' (half of the mark), or 'non-compliance' (no mark).91 Hence, a three-point scale is generally applied. In three instances it has been found expedient to apply a five-point scale, to highlight positions 'between full and partial compliance' and 'between partial and non-compliance' (see B., D.2.3., and E.3. of the scorecard shown below). A two-point scale ('full compliance' or 'non-compliance') is used for indicators in A.1. on the ratification of international agreements.

Some detail on the scorecard, its parameters and the various indicators will now be provided - for purposes of illustration, the example of the scorecard (with the results for Spain) reproduced at the end of this Part should be referred to. The first column ( $A$ ) reflects whether the states at issue accept obligations of 'superior normative force' (in the sense of obligations not 'merely' originating under ordinary legislation) relevant to the right to academic freedom, i.e. whether states have ratified relevant international agreements (10 percent), and whether their constitutions provide appropriate protection (10 percent). Regarding international agreements, the enquiry is whether states have ratified the following four global agreements: the iccpr of 1966 (withits Article 19 on the right to freedom of expression), the Optional Protocol to the iccpr of 1966 (setting up a procedurein terms of which allegations of violations of Covenant rights may be brought before the Human Rights Committee), the icescr of 1966 (with its Article 13 on the right to education), and the Optional Protocol to the icescr of 2008 (setting up a procedure in terms of which allegations of violations of Covenant rights may be brought before the Committee on Economic, Social and Cultural Rights); and the following regional agreement: the echr of 1950, as amended and supplemented (with its Article 10 on the right to freedom of expression). 92 In view of theiruniversal character, slightly more weight has been accorded to the global instruments ( 60 percent). A state that has ratified a treaty but has expressed a reservation to, notably, the right to

$91 \quad$ Karran (n 2)197-198.

92 Although the echr also protects the right to education in Art. 2 of its Protocol No. 1, it does so negatively, stating that ' $\mathrm{n}] \mathrm{o}$ person shall be denied the right to education.' It has convincingly been argued that ' $[t]$ he right to university education is a human right' under the echr. See Tarantino v. Italy, 2013-ii ECtHR 397, 416 (Pinto de Albuquerque, J., partly dissenting). The nature and scope of state obligations flowing from the right to education under the echr remain contentious, however. See Beiter (n 34) 162-166. The European SocialCharter (opened for signature 18 October 1961, ets 35 (enteredinto force 26February 1965)) does not, also not in its revised version (opened for signature 3 May 1996, ets 163 (entered into force 1 July 1999)), contain a right to higher education. 
freedom of expression or the right to education, problematic from the perspective of the right to academicfreedom, will be considered to be 'non-compliant.' Regarding constitutional protection, it will be assessed whether there are adequate, problematic, or seriously deficient/no provisions in the constitutions of states in respect of each of the following:(1)theright tofreedom of expression, (2) the right to academic freedom, and, as aspects of the latter, (3) institutional autonomy, and (4) academic self-governance (60 percent). 93 It will further be assessed whether the normative context of constitutions (e.g. values reflected by relevant provisions, and specific or general limitations clauses) fully supports the effective protection of the rights concerned ( 40 percent).

The second to fifth columns consider whether states have complied with the requirement of adopting legislation providing expressly that academic freedom is to be protected (column B), and legislation satisfactorily concretising institutional autonomy (column C), self-governance (column D), and job security (including 'tenure') (column E) in he. Under column $B$, there is only one indicator, this enquiring whether he legislation contains express provisions on academicfreedom (primarily in the sense of individual freedom to teach and carry out research). Do these comply with notably the Recommendation's criteria on academic freedom and do they show that academic freedom should serve as a guiding principle for activity within he (full compliance)? Or, is there a mere reference to academic freedom, alternatively, are there more elaborate provisions on academic freedom, which, however, reveal various deficits (partial compliance)? Or, is there no reference to academic freedom at all (non-compliance)? Or, is there in fact a situation that may be described as being 'between full and partial compliance' or 'between partial and non-compliance'? The indicator of column B thus applies a five-point scale to assess compliance.

Column C covers indicators on institutional autonomy. The European University Association (eua) monitors on an ongoing basis the extent to which he institutions in the various European states enjoy autonomy. As part of these

93 Provisions on the right to education have not been taken into account. Full-fledged provisions on the right to education are found in only some European constitutions. The notion of protecting economic, social and cultural rights as entailing extensive positive obligations for states is still foreign to constitutional theory in most parts of Europe. Also tenure has not been considered separately here, as 'tenure' as a technical concept is unknown in many European countries. 
efforts, it has produced two reports 94 and administers an online platform, 95 which may usefully be consulted in establishing the elements encompassed by institutional autonomy. unesco's Recommendation does not provide detail in this respect, and only remarks that 'the nature of institutional autonomy may differ according to the type of establishment involved.' 96 The eua thus distinguishes between organisational, financial, staffing, and academic autonomy, 97 and, foreach of these, applies variousindicators to measure compliance. It needs to be emphasised, however, that the eua's work reveals flaws when adjudged from a human rights perspective. 98 Hence, although the eua indicators provide 'a good starting point,' in the end only some of these may usefully be applied (such as the indicators under C.2.) in establishing to what extent he institutions in the European states enjoy autonomy for purposes of this study. The indicators chosen in this assessment will enquire: whether there is a satisfactory, problematic, or seriously deficient/no provision in he

94 T.Estermann and T.Nokkala, UniversityAutonomyin Europe I: Exploratory Study (Final Report, eua, November 2009), retrieved 15 May 2016, http://www.eua.be/typo3conf/ext/bzb _securelink/pushFile.php?cuid=3040\&file=fileadmin/user_upload/files/Publications/ University_Autonomy_in_Europe.pdf; T. Estermann et al., University Autonomy in Europe ii:The Scorecard (FinalReport, eua, November 2011), retrieved 15 May2016, http:// www.eua.be/Libraries/Publications/University_Autonomy_in_Europe_II_-_The_Score card.sflb.ashx.

95 See the website 'University Autonomy in Europe' (eua, 2012), retrieved 15 May 2016, http:// www.university-autonomy.eu, with scorecards for university autonomy in 29 European countries.

96 unesco Recommendation, para. 17.

97 See the eua's Lisbon Declaration: Europe's Universities beyond 2010: Diversity with a Common Purpose, para. 26, retrieved 15 May 2016, http://www.eua.be/typo3conf/ext/ bzb_securelink/pushFile.php?cuid=398\&file=fileadmin/user_upload/files/Lisbon_Con vention/Lisbon_Declaration.pdf.

98 Whereas some of the eua's indicators overtly contradict requirements of international human rights law (see K.D. Beiter, T. Karran and K. Appiagyei-Atua, "Measuring” the Erosion of Academic Freedom as an International Human Right: A Report on the Legal Protection of Academic Freedom in Europe,' Vanderbilt Journal of Transnational Law (forthcoming Vol. 49, 2016)), there is also a problem of a more general nature with the eua's approach to institutional autonomy. The eua's interpretation of institutional autonomy is far too technical in nature. It loses sight of the fact that institutional autonomy constitutes 'the institutional form of academic freedom' (unesco Recommendation, para. 18). Institutional autonomy must be understood to mean the independence of he institutions, enabling these to ensure academics can engage in a free search for the truth for the benefit of society as a whole, and can advance values of intellectual independence. See $n 38$ above. 
legislation expressly protecting institutional autonomy (C.1.) (20 percent), how each of organisational, financial, staffing, and academic autonomy is realised by reference to one or two legitimate key indicators in each instance, each aspect of autonomy weighted equally (C.2.)(40 percent), 99 overall, how wide or narrow the extent of governmental powers are (C.3.) (20 percent), 100 and, finally, as to the extent to which institutional independence is protected against private interests (C.4.) (20 percent). 101

Column D covers indicators on self-governance. The first indicator ascertains whether there is a satisfactory, problematic, or seriously deficient/no provision in he legislation expressly protecting self-governance (D.1.) (10 percent). This is followed by a group of indicators examining the state of self-governance at the level of the he institution (D.2.), and another set of indicators measuring this at the faculty/departmental level (D.3.). As institutional decisions usually bind those adopting decisions at faculty/departmental level, self-governance at the institutional level has been accorded double the weight assigned to selfgovernance at faculty/departmental level(60percent:30 percent). Theindicators seek to ascertain whether he legislation safeguards the right of academic staff to sufficiently participate in the taking of decisions directly or indirectly related to science and scholarship. unesco's Recommendation requires academic staff to be able 'to elect a majority of representatives to academic bodies within the highereducation institution.' 102 Countries willearnhalf the mark where they provide that 50 to 59 percent of the members of the senate (oritsequivalent)aretoberepresentativesof academicstaff(D.2.1.). Thesame

99 The indicators are: organisational autonomy (1. autonomy to determine the rector, 2. autonomy to decide on the internal structure (faculties, departments, etc.)), financial autonomy (1.block grants with/without restrictions, line-item budgets, 2 . express competence to perform commissioned research), staffing autonomy (right to define academic positions and their requirements, and to recruit and promote academic staff), and academic autonomy (1. capacity to determine the selection criteria for bachelor students and to select the latter, 2. whether or not bachelor programmes need not be accredited).

100 This covers the aspect of the form that state supervision takes, i.e. the question whether, additionally to supervising whether legal requirements have been complied with (German: 'Rechtsaufsicht'), the state is also required to review decisions on their merits (German: 'Fachaufsicht'). The former should always be an obligation of the state, the latter constitutes a diminution of institutional autonomy.

101 For example, is there a clear statement in he legislation emphasising that private funding should not compromise the independence of teaching and research in he institutions? Is there a requirement to the effect that he institutions reveal the sources and scope of private funding? Is there a clear restriction of undue influence exercised by the representatives of private interests on the he institution's governing bodies? unesco Recommendation, para. 31. 
applies with regard to the composition of collegial bodies at faculty/departmental level(D.3.1.). A higher percentage, ideally between 60 and 70 percent, will earn them the full mark.103 Whereas the taking of decisionsonessentially academic matters constitutes the core competence of the senate (or its equivalent) or afaculty/departmental representative body, the primary responsibility of directing theinstitution/faculty/departmentaccruestotherector/dean/head of department, who is the institution's/faculty's/department's chief executive officer. The unesco Recommendation does not comment on these positions separately. It does, however, state that academic staff should have the right 'to take part in the governing bodies,' 104 and further enshrines the principle of collegiality, remarking that this includes shared responsibility, the participation of all in internal decision-making, and consultative mechanisms.105 Clearly, this is closest to the primus inter pares model, in terms of which academic staff are to decide on 'their leaders' themselves, choosing them from among themselves, for a certain period of time, after which they become ordinary members of staff again. Under this model, academic staff should also be able to express a lack of confidence in their leaders' ability to lead, where appropriate. Specifically with regard to the rector, Karran has pointed out that, if these arrangements apply, the rector 'is unlikely to take decisions that undermine the academic freedom of the staff, as [he/she] knows that at the end [of his/her] term of office, someone else could be elected as Rector and take retaliatory actions against [him/her].' 106 Indicators on the rector (D.2.2.) or dean/head of department (D.3.2.) (accorded the same weight as indicators on the senate (or its equivalent) or faculty/departmental representative body, respectively) will thus ascertain, firstly, whether these officers come from within the institution/faculty/department and hold a $\mathrm{PhD} /$ are a professor, secondly, whether academic staff can exercise 'control' over who is chosen as the rector or dean/head of department, and, thirdly, whether they can exercise 'control' over the dismissal of the rector or dean/head of department by virtue of a vote of no-confidence. Apart from questions related to how purely academic matters shouldbedealtwith and how he institutions/faculties/departments should

103 The assessment also takes into account whether the provisions on the composition of the senate (or its equivalent) or collegial bodies at faculty/departmental level also comply in all other respects with accepted requirements of academic self-governance (e.g. all categories of academic staff should take part in the election of representatives and be represented in the relevant bodies).

104 unesco Recommendation, para. 31.

105 Ibid para. 32.

106 Karran(n 1)303-304. 
be directed, a final issue relates to the particular way strategic decision-making takes place. Also in this respect, academic staff should have aright to take part in the relevant governing bodies, i.e. those bodies responsible for strategic planning, general teaching/research policy, overall institutional development, preparing the budget, and adopting the he institution's statutes.107 Strategic decision-making-only that at theinstitutionallevel tobeconsidered here108would customarily be the task of the rector (rectorate) and the senate (or its equivalent) and/or - notably and increasingly nowadays - a separate board to which academic staff, external experts, and other stake-holders are elected/ appointed.109 In view of the increased importance of the latter boards in the governance of he institutions, and as the extent to which science and scholarship can flourish within a he institution significantly depends on how 'strategicissues' are resolved, Indicator D.2.3., which focuses on the composition of the body/bodies taking strategic decisions, has been assigned the same weight as indicators under D.2.1. and D.2.2. together. It is submitted that academic staff should ideally have at least 50 percent representation on any such body/bodies (for purposes of strategic decision-making). 110

Finally, Column E covers indicators on security of employment, including 'tenure or its functional equivalent, where applicable.' Indicators concern three topics: duration of contract of service (40 percent) (E.1.), termination of contract of service on operational grounds (30 percent) (E.2.), and prospect of advancement based on objective assessment of competence (30 percent) (E.3.). Regarding the first topic - unesco's Recommendation referring

107 Ultimately, Paragraph 32 of the unesco Recommendation highlights that '[c]ollegial decision-making should encompass decisions regarding the administration and determination of policies of higher education, curricula, research, extension work, the allocation of resources and other related activities ....'

108 At faculty/departmental level, these questions should be resolved by the dean/head of department and staff (representative body).

109 See Eurydice - The Information Network on Education in Europe, Higher Education Governance in Europe: Policies, Structures, Funding and Academic Staff (Eurydice, 2008) 33-42, retrieved 15 May 2016, http://eacea.ec.europa.eu/education/eurydice/documents/ thematic_reports/091EN.pdf, on the typical governance bodies encountered in (European) he institutions.

110 A five-point scale is applied to measure compliance with regard to Indicator D.2.3.: representation $=$ at least $50 \%, 40-49 \%, 30-39 \%$, less than 30\%, but not negligible, or not noteworthy. Where there is a board consisting of external members, and academic staff may determine at least $50 \%$ of its members, this is considered to constitute partial compliance. Where they are not in a position to determine at least $50 \%$ of those members, this is considered to constitute non-compliance. 
to 'continuing employment following rigorous evaluation'll1 - it is to be assessed whether the legal framework of the states concerned envisages permanent contracts for academic staff, or alternatively, commencement on a tenure-track (i.e. during a first phase, 112 a probationary period or fixed-term contracts with long-term prospects). A lowering of the standards of protection may take on various forms: permanent contracts or commencement on a tenure-track at the level of senior positions (e.g. that of associate professor) only (partial compliance), leaving the conclusion of permanent contracts generally to the discretion of the employer (partial or non-compliance), 113 or expressly providing for fixed-term contracts without long-term prospects at even senior levels (non-compliance).114 Indicators on the secondtopic, the termination of contracts of service on operational grounds, relate to requirements in unesco's Recommendation to the effect that potential dismissal of 'tenured' staff should occur 'on professional grounds and in accordance with due process' only.115 Dismissals on grounds of serious misconduct, a flagrant violation of scholarly duties (e.g.fabrication of researchresults or plagiarism), or two or more consecutive negative appraisals of work quality will be permissible, if due process rules are observed.116 Dismissals on operational grounds (i.e. restructuring, down-sizing, reorganisation, or economic difficulties), however, should ideally not take place. They will only be justifiable exceptionally, and provided all alternatives have been considered, appropriate priority criteria have been observed, a formalised procedure has been followed, and

111 unesco Recommendation, para. 46.

112 This would normally be the phase following the award of a doctoral degree. It has been held that this phase typically (and legitimately) is between 5-7 years. See Karran (n 39) 178.

113 Much will depend on whether fixed-term contracts are subject to strict or rather lax requirements as regards legitimate cases of use, maximumnumber of successive contracts, and maximum cumulated duration.

114 By way of exception, Indicator E.1.1. on the legal framework is supplemented by Indicator E.1.2. on the situation in practice, as it were, to verify the purport of legal provisions: $66,7 \%$ or more of academic staff at post-entry levels (i.e. following any stage of doctoral employment) having permanent contracts of service or on a tenure-track $=$ full compliance, $50-66,6 \%=$ partial compliance, and less than $50 \%=$ non-compliance.

115 unesco Recommendation, para. 46.

116 Note should be taken of Paragraph 47 of the unesco Recommendation on 'Appraisal,' Subparagraph (e) stating that the results of appraisal may legitimately be taken into account when 'considering the renewal of employment,' and of Paragraphs 48-51 on 'Discipline and dismissal,' specifically Paragraph 50 on 'dismissal as a disciplinary measure.'See Karran (n39)181-185(figures 7,8), for adescription of due process rulesin this context. 
procedural safeguards have been respected.117 A first indicator (E.2.1.) ascertains whether there is an adequate, problematic, or seriously deficient/no provision in he legislation expressly prohibiting dismissals of specifically, but not solely, 'academic staff with permanent contracts' on operational grounds, or alternatively, providing strict protection in cases of such dismissals. $118 \mathrm{~A}$ second indicator of equal weight (E.2.2.) enquires as to the level of protection afforded to academic staff, as defined, in cases of dismissals on operational grounds under 'ordinary' civil service and/or labour law. Finally, as regards the topic of a prospect of advancement based on an objective assessment of competence, since academic freedom is to be protected by restricting dismissal, it follows, by way of implication, that academic freedom should also not be infringed by preventing advancement in the academic career where it should take place. There should be procedures in place (also capable of being initiated by the academic concerned) in terms of which promotion is granted, provided that defined scholarly criteria have been met as objectively assessed, without the need for the academic having to newly apply for a higher position within his/her institution on a competitive basis. Indicator E.3. thus assesses whether legislation makes adequate provision (including, e.g., through a tenure-track system) for advancement to a higher position based on an objective assessment of competence. 119

\section{$7 \quad$ Modus Operandi and Practical Difficulties Encountered in the Endeavour}

The assessment of the legal protection of the right to academic freedom in Europe undertaken here considers only public institutions of he and, among

117 See Karran (n 39) 179-181, 184-185 (figures 5, 6, 8), for a description of due process rules in this context.

118 Such a provision may largely be dispensed with where academic staff are civil servants whose discharge on very limited grounds, notably serious misconduct, is strictly regulated in civil service legislation.

119 Indicator E.3. applies a five-point scale: adequate legislation, legislation with certain deficits, legislation with more serious deficits, legislation with substantial deficits, or no legislation. Where relevant procedures are provided for in a prominent and sector-wide collective agreement, in government regulations, or in the statutes of he institutions generally, these will, depending on their specific nature, be rated to be 'in partial compliance' or 'between partial and non-compliance.' 


\begin{tabular}{|c|c|c|c|c|c|}
\hline & $\begin{array}{l}\text { A. The Ratification of Inter- } \\
\text { national Agreements and } \\
\text { Constitutional Protection } \\
(20 \%)\end{array}$ & $\begin{array}{l}\text { B. The Express Protec- } \\
\text { tion of Academic } \\
\text { Freedom in he } \\
\text { Legislation }(20 \%)\end{array}$ & $\begin{array}{l}\text { C. The Protection of Insti- } \\
\text { tutional Autonomyinhe } \\
\text { Legislation }(20 \%)\end{array}$ & $\begin{array}{l}\text { D. The Protectionof } \\
\text { Self-Governance inhe } \\
\text { Legislation }(20 \%)\end{array}$ & $\begin{array}{l}\text { E. The Protection of } \\
\text { Job Security (in- } \\
\text { cluding 'Tenure') in } \\
\text { Relevant Legisla- } \\
\text { tion (20\%) }\end{array}$ \\
\hline & $\begin{array}{l}\text { 1. The Ratificationof Interna- } \\
\text { tional Agreements }(10) \mathbf{1 0} \\
\text { 1.1. Global Level }(6) \\
\text { 1.1.1. International Covenant on } \\
\text { CivilandPolitical Rights } \\
\text { (Art. } 19, \text { Right to Freedom } \\
\text { of Expression) }[0-1,5] \mathbf{1 , 5} \\
\text { 1.1.2. Optional Protocol to the } \\
\text { International Covenant on } \\
\text { Civil and Political Rights } \\
\text { (International Petition } \\
\text { Procedure) [0-1,5]1,5 } \\
\text { 1.1.3. International Covenant } \\
\text { onEconomic, Socialand } \\
\text { Cultural Rights } \\
\text { (Art.13, Right toEduca- } \\
\text { tion) }[0-1,5] \mathbf{1 , 5}\end{array}$ & $\begin{array}{l}\text { [0-2,5-5-7,5-10 (x2)] } \\
\mathbf{7 , 5} \\
\text {-0-No Reference to } \\
\text { Academic Freedom at } \\
\text { All (Non-Compliance) } \\
\text { - 2,5-Provision(s) } \\
\text { Seriously Falling Short } \\
\text { of Defined Standards } \\
\text { (Between Partial and } \\
\text { Non-Compliance) } \\
\text { - 5-Mere Reference } \\
\text { to Academic Freedom/ } \\
\text { Provisions Revealing } \\
\text { Various Deficits(Partial } \\
\text { Compliance) }\end{array}$ & $\begin{array}{l}\text { 1. } \frac{\text { Provisionon Institutional }}{\text { Autonomy }[0-2-4] 4} \\
\text { 2. Autonomy in Detail }(8) 2,5 \\
\text { 2.1. Organisational (2) } \\
\text { 2.1.1. Autonomy toDeter- } \\
\text { mine Rector [0- } \\
0,5-1] \text { 0 } \\
\text { 2.1.2. Autonomy to Deter- } \\
\text { mine Internal Struc- } \\
\text { tures [0-0,5-1] 0 } \\
\text { 2.2. Financial (2) } \\
\text { 2.2.1. StateGrantasBlock } \\
\text { Grant [0-0,5-1]1 } \\
\text { 2.2.2. Express Competence } \\
\text { to Perform } \\
\text { Commissioned } \\
\text { Research [0-0,5-1]1 }\end{array}$ & $\begin{array}{l}\text { 1. } \frac{\text { Provision on Academic }}{\text { Self-Governance }[0-} \\
\underline{1-2] \mathbf{0}} \\
\text { 2. } \frac{\text { AcademicSelf-Governance }}{\text { atInstitutional Level }(12)} \\
\mathbf{8 , 5} \\
\text { 2.1. Senate (oritsEquiva- } \\
\text { lent) - Composition } \\
\text { [0-1,5-3] } \mathbf{3} \\
\text { 2.2. Rector (3) } \\
\text { 2.2.1. Academic Position/ } \\
\text { Qualification of } \\
\text { Rector [0-0,5-1] } \mathbf{1} \\
\text { 2.2.2. Determining the } \\
\text { Rector [0-0,5-1] } \mathbf{0 , 5} \\
\text { 2.2.3. Dismissing the Rector } \\
{[0-0,5-1] \mathbf{1}}\end{array}$ & $\begin{array}{l}\text { 1. Duration of } \\
\frac{\underline{\text { Contractof Service }}}{(8) \mathbf{8}} \\
\begin{array}{l}\text { 1.1. Regulatory Frame- } \\
\text { work [0-2-4] } 4\end{array} \\
\text { 1.2. Situation in Prac- } \\
\text { tice [0-2-4] } 4 \\
\text { 2. } \frac{\text { Termination of }}{\text { Contractof Service }} \\
\frac{\text { on Operational }}{\text { Grounds }(6) 3} \\
\text { 2.1. Provision on } \\
\text { Termination on } \\
\text { Operational } \\
\text { Grounds in } \\
\text { he Legislation }[0- \\
\text { 1,5-3] } \mathbf{1 , 5}\end{array}$ \\
\hline
\end{tabular}


1.1.4. Optional Protocol to the International Covenant on Economic, Social and Cultural Rights (International Petition Procedure) $[0-1,5] \mathbf{1 , 5}$

1.2. Regional Level (4) European Convention on Human Rights (Art. 10, Right to Freedom of Expression) [0-4] 4

2. Constitutional Protection (10) 10

2.1. Provision on Right to Freedom of Expression [0-1-2] 2

2.2. Provision on Right to Academic Freedom [0-1-2]2

2.3. Reference to Institutional Autonomy $[0-0,5-1] 1$

2.4. Reference to Academic SelfGovernance [0-0,5-1]1

2.5. Robustness of Provisions [0-2-4] 4

Total: 20
- 7,5 - Some or Other 2.3. Staffing (2)

Deficit in Otherwise

Commendable Provi-

sions(BetweenFulland

Partial Compliance)

- 10 - Academic

Freedom Serves as

Guiding Principle for

Activity within he

(Full Compliance)_

\section{Total: $7,5 \times 2=15$}

Right to Define Academic Positions in he Institutions and their Requirements, and to Recruit and Promote Academic Staff [0-1-2] 0

2.4. Academic (2)

2.4.1. Capacity to Determine Selection Criteria for BachelorStudentsand to Select the Latter [0-0,5-1] $\mathbf{0 , 5}$

2.4.2. Whether or Not Bachelor Programmes Need to be Accredited [0-0,5-1] 0

3. ExtentofGovernmental Powers [0-2-4]2

4. Institutional Independence vis-à-vis Private Interests [0-2-4] 0

Total: 8,5
2.3. Participation in Strategic Decision-Making (through Senate or its Equivalent, or Otherwise) [0-1,5-3-4,5-6]3

3. Academic Self-Governance at Faculty/Departmental Level (6) 3,5

3.1. Collegial Bodies(3)

3.1.1. Existence of Collegial Bodies [0-0,5-1]1

3.1.2. Composition of Collegial Bodies [0-1-2] 1

3.2. Dean/Head of Department (3)

3.2.1. Academic Position/ Qualification ofDean/ Head of Department [0-0,5-1] 1

3.2.2. Determining the Dean/ Head of Department [0-0,5-1] 0,5

3.2.3. Dismissing the Dean/ Head of Department $[0-0,5-1] 0$
2.2. Protection in the Case of Termination on Operational Grounds in Terms of Civil Service/Labour Legislation $[0$ $1,5-3] \mathbf{1 , 5}$

3. Prospect of Advancement Based on Objective Assessment of Competence

[0-1,5-3-4,5-6]0

\section{Total: 11}

Total: 12 
these, only universities.120 The right to academic freedom naturally also needs to be respected in private institutions of he, though there may be differences in the scope of thatright in that context. 121 Further, infringements of academic freedom seem more prevalent in universities than, for example, polytechnics, which may not be as extensively involved in original research as universities.122 These restrictions in the ambit of the enquiry were necessary in the light of limited human and time resources available to examine all relevant data. The analysis entailed an examination of 30 European he systems. States with afederal structure in the field of he required a particular approach. In the case of Belgium, the he systems of Flanders andWallonia were considered separately, omitting the German-speaking region. In the case of Germany with different he systems in each of the 16 Länder, it has been decided to study the situation in the two Länder with the most inhabitants, Bavaria and North RhineWestphalia - one third of Germany's population living in these Länder. The two he systems also reveal interesting differences, both Länder traditionally having been governed by conservative and social-democrat governments, respectively. As Germany's Hochschulrahmengesetz (Framework Act on Higher Education) in its version of 1999123 is still on the law books (its abolition lingering on the political agenda), differences among the various he systems, though increasing, remain within bounds. Where appropriate, developments in the other Länder have been taken note of. Regarding Spain, certain powers in the field of he regulation rest with the autonomous regions. As for the United Kingdom, the situation essentially in England has been studied (more than 80 percent of the uk's population living here), giving some consideration to elements of the Scottish system.

120 Moreover, it only considers academic freedom of academic staff, but not that of students. It also does not consider artistic freedom, which is a related but separate concept.

121 See, e.g., Tarantino v. Italy, 2013-ii ECtHR 397, 416 (Pinto de Albuquerque, J., partly dissenting) ('States Parties' margin of appreciation is wider with regard to the regulation of State schools and narrower with regard to that of private schools. An even narrower margin of appreciation applies a fortiori to higher education, where institutional autonomy plays a pivotal role. (footnote omitted) Conversely, the more the State funds private schools and universities, the wider its margin of appreciation. (emphases omitted)').

122 Paragraph 1(e) of the unesco Recommendation states that " institutions of higher education" means universities, other educational establishments, centres and structures of higher education, and centres of research and culture associated with any of the above, public or private, that are approved as such either through recognised accreditation systems or by the competent state authorities.'

123 Hochschulrahmengesetzin the version of 19 January 1999, bgbl.i, at 18, lastamended by Art. 2 of Law, 12 April 2007, bgbl. i, at 506. 
The actual legislation of eu states constituted the primary source of information for purposes of the assessment. Legislation as in force at the beginning of 2014 has been studied.124 Where relevant language competencies existed (Dutch/Flemish, English, French, German, and Spanish), the original language versions of the legislation were consulted. In other cases, recourse was had to official or unofficial English-language translations that seemed reliable. In a few cases, no reliable English-language versions could be traced (Croatia, Greece, and Italy), probably because the states concerned had adopted new he legislation relatively recently. In these cases, but also to take account of recent amendments to he laws in the case of other states, online translation tools had to be utilised.125 In all instances has it been sought to verify the correctness of information by studying relevant secondary literature (journalistic and academic texts, and information available in online databases126), or information provided by states themselves. 127 It will be appreciated that coping with voluminous and diverse sets of legislation in different languages is a daunting task. An error margin of up to three percent is thus conceivable.

124 As North Rhine-Westphalia (Germany) adopted a new Hochschulzukunftsgesetz (Act on the Future of Higher Education) in September 2014, this was examined for purposes of the comparison.

125 Citations from the constitutions, laws, and regulations used here should not be seen to reflect official translations, but rather are own renderings of the texts in the light of all sources available.

126 In particular, these online databases were consulted: the Eurydice/Eurypedia website (maintained by the European Commission's Education, Audiovisual and Culture Executive Agency (eacea)), Eurydice and Eurypedia providing information on European education systems and policies: retrieved 15 May 2016, https://webgate.ec.europa.eu/fpfis/ mwikis/eurydice/index.php/Main_Page; the website of the Organisation for Economic Co-operation and Development (oecd), making available online, inter alia, the oecd Programme on Institutional Management in Higher Education's journal Higher Education Management and Policy: retrieved 15 May 2016, http://www.oecd-ilibrary.org/edu cation/higher-education-management-and-policy_17269822; the website of the European University Association, supplying useful information on university autonomy: retrieved 15 May 2016, http://www.eua.be; the website of the Center for Higher Education Policy Studies of the University of Twente (Netherlands), containing a collection of publications on he adopting an international comparative perspective: retrieved 15 May 2016, http:// www.utwente.nl/bms/cheps.

127 Amongst others, the websites of the ministries responsible for he in the various eu Member States were thus consulted. Furthermore, a questionnaire asking eu Member States to provide information on the legislative framework in place for the protection of academic freedom was sent out to states on 3 October 2013. The response rate has been rather modest, with only one third of the states having responded. Nevertheless, of the replies that were received, some, like those from Denmark, Hungary, Slovakia, or Sweden, were very instructive. 
The Legal Protection of the Right to Academic Freedom in Europe: The Results of the Assessment

The following six headings provide a brief overview of state performance with regard to each of the five columns of the scorecard, and overall. Each heading provides concise information on trends identified, some examples, and a country ranking in the form of a table. Detail on individual state performance for each specific indicator is contained in the Annex to this article. 128

\subsection{The Ratification of International Agreements and Constitutional Protection}

All 28 eu Member States have ratified the iccpr and the icescr of 1966 (Indicators A.1.1.1. and A.1.1.3., respectively). The uk is the only Member State not to have ratified the Optional Protocol to the iccpr of 1966 (Indicator A.1.1.2.). Claims under Article 19 on the right to freedom of expression alleging that the uk has violated academic freedom can thus not be brought before the Human Rights Committee. In view of the recentness of the adoption of the Optional Protocol to the icescr in 2008, only eight states so far (Belgium, Finland, France, Italy, Luxemburg, Portugal, Slovakia, and Spain) have ratified it (Indicator A.1.1.4.). The Optional Protocol to the icescr entered into force on 5 May 2013.129 A number of states have expressed reservations with regard to Article $20 \mathrm{iccpr}$, which prohibits 'any propaganda for war' (Para. 1), and 'any advocacy of national, racial or religious hatred that constitutes incitement to discrimination, hostility or violence' (Para. 2). Malta and the uk reserve the right not to adopt legislation with regard to Article 20 as a whole. Belgium and Luxemburg do so as regards Article 20(1) on war propaganda. Ireland defers the right to adopt legislation on a specific criminal offence in the sphere of Article 20(1). Also Denmark, Finland, the Netherlands, and Sweden do not want to apply Article 20(1), Finland stating that applying this provision 'might

128 Where appropriate, the footnotes include references to literature on academic freedom as protected in the states assessed, available in English, French, German, or Spanish, focusing on more recent literature adopting a legal or quasi-legal approach. Regarding the three eu states with the largest populations, Germany, the uk, and France, reference should, as regards Germany and the uk, be had to Barendt (n 27) (see, specifically, the references to furtherliterature at316-318), and, as regardsFrance, to O. Beaud, Les libertés universitaires à l'abandon? Pour une reconnaissance pleine et entière de la liberté académique (Dalloz, 2010) (and the references to further literature there).

129 Status of ratification as at 19 March 2015 as reflected in the online databases of the un Treaty Collection, retrieved 15 May 2016, https://treaties.un.org/Pages/Treaties. asp $\mathrm{x}$ ?id=4\&subid=A\&lang=en. 
endanger the freedom of expression referred [to] in article 19 of the Covenant.' Seeing that a wider consensus, holding that restrictions on war propaganda and hate speech constitute justifiable limitations of the right to freedom of expression, is absent in Europe (as is apparent from the many reservations expressed to Article 20), reservations to Article 20 have not been considered to amount to 'non-compliance' in the present analysis.130 Malta, however, has made a problematic reservation with regard to Article 22 iccpr on the right to freedom of association, stipulating that it 'reserves the right not to apply article 22 to the extent that existing legislative measures may not be fully compatible with this article.' All eu Member States are further bound by the relevant provisions of the echr, as amended and supplemented (Indicator A.1.2.). 131

Of all eu Member States, the constitutions of only Portugal and Spain meet all the criteria to earn full marks in the rubric 'constitutional protection.' The Spanish Constitution 1978, for example - in a robust constitutional contextprovides express protection for the rights to freedom of expression and to academic freedom, there also being explicit references to institutional autonomy and self-governance:

Article 20

1. The following rights are recognised and protected:

a) to freely express and disseminate thoughts, ideas, and opinions by word, in writing, or by any other means of communication;

b) to literary, artistic, scientific, and technical production and creation [freedom of science];

c) to academic freedom ['la libertad de cátedra,' literally meaning 'the freedom of the academic chair'];

130 It has been stated that ' $[\mathrm{h}]$ ere the issue is balancing two competing human rights [absence of discrimination $\mathrm{v}$. freedom of expression], rather than a conflict between human rights and another value. Any resolution will require restricting the range of at least one of these rights. Therefore, any approach that plausibly protects the conceptual integrity of both rights must be described as controversial but defensible.' See J. Donnelly, 'The Relative Universality of Human Rights,' Human Rights Quarterly 29(2) (2007) 281-306, at 302-303.

131 Status of ratification as at 21 March 2015 as reflected on the Council of Europe's official Treaty Office website, retrieved 15 May 2016, http://www.coe.int/en/web/conventions. The focus regarding the echr has been on Art. 10 on the right to freedom of expression, disregarding notably Protocol No. 12 on an 'autonomous' non-discrimination provision. 
d) to freely communicate or receive accurate information by any means of dissemination whatsoever. Thelaw shallregulate theright to invoke personal conscience and professional secrecy in the exercise of these freedoms.

4. These freedoms find their limitation in the respect for the rights recognised in this Title, in the provisions of the laws implementing it, and, especially, in the right to honour, to privacy, to one's own image, and to the protection of youth and childhood.

Article 27

1. Everyone has the right to education....

7. Teachers, parents, and, where appropriate, students shall participate in the control and administration of all centres maintained by the Administration out of public funds, under the terms established by the law.

10. The autonomy of universities is recognised, under the terms established by the law.

The constitutions of all eu Member States 132 protect the right to freedom of expression (Indicator A.2.1.). Express provisions are found in the (written) constitutions of 27 states. In the uk, this right should be considered part of that state's unwritten constitution.133 Whereas the provisions of the Greek, Irish, and Romanian Constitutions are problematic ('partial compliance'), that of the Hungarian Fundamental Law is seriously deficient ('non-compliance'). Article 14(3) of the Greek Constitution 1975, for example, allows the seizure of newspapers and other publications in cases of 'an offence against the Christian or any other known religion,' or 'an insult against the person of the President of the Republic.'134 The Hungarian Fundamental Law 2011 substantially constrains political campaigning in non-public media, and provides that

132 This refers to the constitutions and constitutional-status documents as in force on 1 January 2014. It is refrained from providing full official citations of these texts here.

133 There is some case law holding that '[there exists] a constitutional right to freedom of expression in England.' Moreover, the Human Rights Act, 1998, ch. 42, has modified the largely 'residual nature' of human rights protection available under common law. See E. Barendt, 'Freedom of Expression in the United Kingdom under the Human Rights Act 1998,' Indiana Law Journal 84(3) (2009) 851-866, at 852-855.

134 The Irish Constitution 1937 forbidsblasphemy (art.40(6)(1)(i)), the Romanian Constitution 1991 'defamation of the country and the nation' (art. 30(7)). 
freedom of speech may not violate 'the dignity of the Hungarian nation,' in Article ix(3) and (5), respectively.

Express provisions on the right to academic freedom (Indicator A.2.2.)-in the form of aright to freedom of science 135-may be found in the constitutions of 18 countries. 136 These protect the right either as part of provisions (also) addressing the right to freedom of expression (Germany and Spain), the right to education/educational rights (Austria, Finland, Greece, Italy, and Sweden), rights related to science, arts, culture, universities and research institutions (Bulgaria, Croatia, Estonia, Hungary, Latvia, Lithuania, Poland, Slovakia, and Slovenia), theright tofreedom of thought, conscience, andreligion(Czech Republic), or both the right to education/educational rights and rights related to science, arts, and culture (Portugal). The provisions contained in the Czech, Greek, and Hungarian Constitutions may be considered to be problematic ('partial compliance'). Regarding the Czech Charter of Fundamental Rights and Freedoms 1992, it is submitted that the right to freedom of thought, conscience, and religion in Article 15 provides too narrow a basis as to cover all aspects of therighttoacademic freedom(Art. 15(2)). Article 16(8) of the Greek Constitution 1975 prohibits the establishment of private universities, thereby also preventing opportunities for diversified notions of academic freedom to flourish in different contexts. 137 Although academic freedom does require regulation, the provisions of Article x(1) of the Hungarian Fundamental Law 2011 -also in the light of the Constitution's generally paternalistic, even authoritarian, stance - to the effect that the right to academic freedom is ensured 'within the framework laid down in an Act' does not augur too well for the protection of that right.

Express provisions on institutional autonomy (Indicator A.2.3.) are contained in 15 constitutions (Austria, Bulgaria, Croatia, Estonia, Finland, North Rhine-Westphalia (Germany), Greece, Hungary, Italy, Lithuania, Poland, Portugal, Romania, Slovenia, and Spain), provisions on self-governance (Indicator A.2.4.) in only three (Bavaria(Germany), Portugal, and Spain). All of these are 'fully compliant,' except Hungary's provisions on institutional autonomy,

135 Although, as has been explained at $\mathrm{n} 27$ above, there are differences between the right to freedom of science-potentially in the sense of 'Wissenschaftsfreiheit' or 'the right to free scholarship' - and the right to academic freedom, the approach here has been not to differentiate between the two. The Spanish Constitution 1978, as has been seen, protects both freedom of science (art. 20(1)(b)) and academic freedom (art. 20(1)(c)).

136 In the uk, 'there is no constitutional guarantee of academic or scientific freedom.' See Barendt (n 27)74-75.

137 Art. 13(4) icescr protects 'the liberty of individuals and bodies to establish and direct educational institutions.' 
which must be held to be 'non-compliant.'138 Article x(3) of the Hungarian Fundamental Law 2011 provides that ' $[\mathrm{h}]$ igher education institutions shall be autonomous in terms of the content and the methods of research and teaching; their organisation shall be regulated by an Act. The Government shall, within the framework of an Act, lay down the rules governing the financial management of public higher education institutions and shall supervise their financial management.' 139

Finally, regarding the robustness of constitutional provisions (Indicator A.2.5.), the question was whether the normative context of constitutions (values reflected by relevant provisions, specific or general limitations clauses, etc.)fully supports theeffectiveprotection of therightsconcerned, specifically the right to academic freedom.140 It is interesting to note, for example, that Article 5 of the German Basic Law 1949, in Paragraph 1, protects the right to freedom of expression, and, in Paragraph 2, allows this to be subjected to limitations imposed by law to protect, for example, young persons or the right to personal honour, whereas, the right to freedom of science, research, and teaching, in Paragraph 3 , may not be subjected to limitations. The law may regulate, but not limit the latter, it thus enjoying enhanced protection relative to the right to freedom of expression. The Estonian Constitution 1992 (Art. 123(2)), the Greek Constitution 1975 (Art. 28(1)), and the Polish Constitution 1997 (Art. 91(2)), itmay beobserved, grantinternationalagreements (naturally also those dealing with human rights) priority over ordinary legislation. In Austria, the echr has even been accorded the same status as the constitution (Art. ii No.7,FederalConstitutionalLaw of 4March 1964). Many constitutions, such as those of Bulgaria, Croatia, Greece, Italy, Lithuania, Malta, Portugal, or Spain, moreover, call upon states to actively promote the development of science, arts, and culture, this implicitly requiring that respect for academic freedom be furthered. Factors negatively affecting protective standards encompass, for example, excluding non-citizens from the protection against discrimination on the ground of political opinions (see Malta), or adopting far-reaching

138 See Hungarian Helsinki Committee, Eötvös Károly Policy Institute \& Hungarian Civil Liberties Union, Main Concerns Regarding the Fourth Amendment to the Fundamental Law of Hungary (Statement, 26 February 2013) point 9 (stating that 'the Fourth Amendment entirely abolishes the autonomy of universities in financial questions').

139 Art. 9(4)(d) of the Hungarian Fundamental Law 2011 further provides for the President of the Republic to appoint university rectors. A similar provision may be found in Art. 102(1)(h) of the Slovak Constitution 1992.

140 It may be noted that all those states whose constitutions do not contain express provisions on the right to academic freedom have maximally been considered to be in "partial compliance' in thisrespect. 
Table 1 Country Ranking-Ratification of International Agreements and Constitutional Protection

Country

Percentage \& Score /

20 in brackets

1. Portugal, Spain

$100(20)$

2. Finland, Italy

$95(19)$

3. Slovakia

$90(18)$

4. Austria, Bulgaria, Croatia, Estonia, Germany,

$\mathbf{8 7 , 5}(17,5)$

Lithuania, Poland, Slovenia

5. Latvia, Sweden

$\mathbf{8 2 , 5}(16,5)$

Average

6. Czech Republic, Greece

$78,04(15,61)$

$\mathbf{7 7 , 5}(15,5)$

7. Belgium, France, Luxemburg

70 (14)

8. Cyprus, Denmark, Netherlands, Romania

$\mathbf{6 2 , 5}(12,5)$

9. Hungary, Ireland

$\mathbf{5 7 , 5}(11,5)$

10. Malta, United Kingdom

55 (11)

constitutional amendmentsentailing a generalerosion of universally accepted constitutional principles (see Hungary). 141

\subsection{The Express Protection of Academic Freedom in Higher Education Legislation}

If constitutional provisions on the right to academic freedom legitimately may be rather concise, then - in accordance with what has been stated regarding the requirement of 'legislation' 142 -all salient aspects of that right need to be concretised and operationalised by way of parliamentary legislation (Indicator B). Further detail can be regulated in subordinate legislation. A state's Act on Higher Education should thus make it clear that academic freedom (stricto sensu) entails a right to carry out research, a right to teach, and a right to study without undue restrictions. Ideally, each of these elements should then be defined. The recent Act on the Future of Higher Education of September 2014 of North Rhine-Westphalia(Germany), forexample, 143 providesin Section 4:

141 See Maltese Constitution 1964, art. 45(1), (3), (4)(b). See n 138 above regarding Hungary. For detail on individual state performance regarding Indicator A.2.5., see the Annex.

142 See Part 2 above.

143 Hochschulzukunftsgesetz(hzg nrw), 16September2014, gv.nrw. 2014, No. 27,29September 2014, 543. See Barendt (n 27) 117-160, on the legal protection of academic freedom 
(1) The Land and institutions of higher education shall guarantee that the members of an institution, in fulfilling their duties, are in a position to exercise their rights in the spheres of teaching and research as protected in the first sentence of Article 5(3) of the Basic Law and in this law. Institutions of higher education shall guarantee in particular the freedom to disseminate and exchange scholarly views.

(2) Freedom of research shall cover in particular the topic of research, the methodological approach applied, and the evaluation and dissemination of research findings. Freedom of teaching shall cover in particular the holding of classes within the framework of the teaching duties allocated, including the way classes are structured in terms of content conveyed and methods applied, as well as the right to express scholarly ... views on doctrinal issues. Without prejudice to study and examination regulations, freedom of study shall cover in particular the free choice of classes, the right, within a study course, to freely choose one's areas of focus, as well as the formulation and expression of scholarly ... views also on the content, structure, and holding of classes.

(3) Freedom of research, of teaching, ... and of study shall not absolve any person from allegiance to the Basic Law. Decisions by the competent bodies of an institution of higher education may be taken to the extent that they refer to the organisation of research activities as well as of teaching and study activities, and the proper implementation of the latter. Beyond that, they may be taken to the extent that they refer to the promotion and coordination of research projects, the formulation of the areas of focus for research and the evaluation of research ..., the adoption and observance of study and examination regulations, fulfilment of the mandate to provide further education and the evaluation of teaching ... as well as guaranteeing the orderly pursuit of studies. Decisions under sentences 2 and 3 shall not impair freedom of research and teaching....

Furthermore, legislation should reflect that academic freedom serves as a guiding principle for activity within he, as would be evidenced by 'academic freedom' forming part of a general part of the he Act on 'general principles' and/or it being referred to in various contexts throughout he legislation. Latvia's Law on Institutions of Higher Education of 1995, for example, in Chapter 1 on 'General Provisions,' in Section 6, specifically dealing with

in Germany. Seeibid317-318, for a select bibliography of relevant literature on the situation in Germany. 
'Academic Freedom,' requires academic freedom to be ensured in institutions of he (Para. 1), to then shed some light on the meaning of each of freedom of study, freedom of research, and freedom of teaching (Paras. 2, 3, and 4, respectively).144 References to academic freedom recur in various sections of the Law: Institutions of he are thus expected to guarantee the academic freedom of academic staff and students in their statutes (Sect. 5(6)). The rector is called upon to protect academic freedom of staff and students (Sect. 171(4)). The academic arbitration tribunal - as one of the organs of an institution of he provided for by the Law -is competent to consider claims submitted by staff and students to the effect that their academic freedom has been restricted or infringed (Sect. 19(1)(1)). All members of staff are obliged to promote freedom of study, research, and teaching (Sect. 26(2)). Students' rights cover the right of students to exercise their rights relating to freedom of study and research (Sect. 50(1)(4)). 145

Legislation should, moreover, spell out that members of the academic staff, in exercising their academic freedom, are bound by a duty of 'scholarly honesty,' requiring them to obey 'the generally accepted principles of good scholarly practice' - thus Section 4(4) of the North Rhine-Westphalian Act on

144 Augstskolu likums, 2 November 1995, Latvijas Vèstnesis 179 (462), 17 November 1995, Zin,otājs 1, 11 January 1996. To mention another example, also Croatia's recent Act on Science and Higher Education of 2013 (Zakon o znanstvenoj djelatnosti i visokom obrazovanju, Narodne novine broj 123/03, 198/03, 105/04, 174/04, 2/07-ousrh, 46/07, 45/09, 63/11, 94/13, 139/13) clearly articulates that academic freedom constitutes a guiding principle: Art. 2(3) states: 'Highereducation shall be based on:-Academic freedom, academic self-governance, and university autonomy, ...-Reciprocity and partnership among members of the academic community, - the European humanistic and democratic tradition ...-Respect for and recognition of human rights, ....' Art. 4(2) and (3) further provide for academic freedom, academic self-governance, and university autonomy 'in accordance with the Constitution, international agreements and this Act.'

145 Similarly, Austria's Universities Act of 2002 (Bundesgesetz über die Organisation der Universitäten und ihre Studien (Universitätsgesetz 2002-ug) StF: bgbl. i Nr. 120/2002 (nr: gp xxi rv 1134 ab 1224 S. 111; br: 6697 ab 6717 S. 690)), in Section 2, entitled 'Guiding Principles,' refers to freedom of science, to then concretise this in various parts of the Act, addressing, for instance, the conclusion of target agreements with academic staff $(\S 20(5))$, the protection of personal conscience of those involved in research ( $§ 105)$, or the dismissal of academic staff ( $\$ 113)$. See W. Berka, 'Wissenschaftsfreiheit an staatlichen Universitäten:Zur Freiheit und Verantwortung des Wissenschaftlers,' in K. Weber et al. (eds.), Vom Verfassungsstaat am Scheideweg: Festschrift für Peter Pernthaler (Springer, 2005) 67-48, on the protection of the right to academic freedom in public universities in Austria in terms of the Universities Act of 2002. 
the Future of Higher Education of 2014 (Germany). 146 Article 310 of the Romanian National Education Law of 2011147 stipulates that plagiarism, the fabrication of research findings, and the provision of false information in applications for funding constitute 'serious violations of proper conduct in scientific research and university activities.' It may be noted that Article 18 of the Lithuanian Law on Higher Education and Research of 2009148 creates the position of a supervisor of academic ethics and procedures, a state officer who examines complaints and initiates investigations regarding the violation of academic ethics and procedures.

Finally, legislation should make it clear that he institutions themselves are also obliged to respect the academic freedom of members of the academic staff. The French Code de l'Éducation, for instance, emphasises that 'universities and institutions of higher education shall guarantee [to academic staff] the means for exercising their teaching and research activities in suchconditions of independence and serenity as are indispensable for reflection and intellectual creation.' 149 Institutional structures need to be established to facilitate the internal enforcement of rights in this respect. As has been indicated, Latvia's Law on Institutions of Higher Education of 1995150 provides, in Section 19, for an internal academic arbitration tribunal, competent to receive 'submissions of students andacademic staff regarding arestriction orinfringement of academic freedom and [other] rights.'

The assessment revealed that the he legislation of Austria, Croatia, France, North Rhine-Westphalia (Germany), Latvia, Lithuania, and Slovakia contains express provisions on academic freedom largely in compliance with generally agreed criteria on academic freedom. The provisions show that academic freedom serves as a guiding principle for activity within he ('full compliance'). A second group of he systems were considered to have performed less than wholly satisfactory ('between full and partial compliance'), namely those of Bulgaria, the Czech Republic, Finland, Bavaria (Germany), Ireland, Luxemburg, Romania, and Spain. Within this group, some or other deficit in the otherwise commendable legislative provisions could be identified in each

146 Hochschulzukunftsgesetz (n 143).

147 Legea educaţiei naţionale, Law No. 1, 5 January 2011, Monitorul Oficial al României, Partea i, 30 August 2013.

148 Lietuvos Respublikos mokslo ir studijųistatymas, 30 April 2009, Nr.xi-242, Žin., 2009, Nr. 54-2140, 61, 101.

149 Codedel'Éducation, art.L.123-9. See generally Beaud (n 128), on the protection of academic freedom inFrance.

150 Augstskolu likums (n 144). 
case. The Bulgarian Higher Education Act of 1995,151 in Article 19(3), provides that '[a]cademic autonomy shall include academic freedom, academic selfgovernance, and inviolability of the premises of an institution of higher education.' It should rather have been made clear that 'academic freedom' is the superseding right covering the others, including institutional autonomy. The latter finds its confines in individual academic freedom, not the other way round.152 The Czech Act on Higher Education Institutions of 1998,153 in Part 1 on 'Fundamental Provisions,' in Section 4, after emphatically proclaiming that academic freedom is to be guaranteed in he institutions goes on to enumerate its constituent elements. Nowhere in the remainder of the Act, however, is academic freedom again referred to when concretising the legal framework applicable to he. The Higher Education Act of 2006 of Bavaria (Germany),154 in Article 6(3), provides that the statutes of he institutions may regulate when permission to publish may have to be obtained, stipulating - vaguely, but rather drastically - that this may be denied 'if by reason of the publication material interests of an institution of higher education would be affected.'

A third group of he systems (held to be in 'partial compliance'), namely those of Flanders (Belgium), Wallonia (Belgium), Cyprus, the Netherlands, and Poland, merely refer to the principle of academic freedom in their he legislation.155 Article 8 of the Wallonian Décret définissant le paysage de

151 Закон за висшето образование, Обн., ДВ, бр. 112 от 27.12.1995 г. [Higher Education Act, prom. State Gazette No. 112, 27 December 1995].

152 A similar conceptual problem is encountered in Art. 6 of the Italian Law of 9 May 1989, No. 168, on the Establishment of the Ministry of Universities and Scientific and Technological Research (Legge del 9 maggio 1989, n. 168, Istituzione del Ministero dell'università e della ricerca scientifica e tecnologica, Gazz. Uff. 11 May 1989, No. 108, S.O.), Art. 74 of the Portuguese Law on the Legal Status of Institutions of Higher Education of 2007 (Lei n. ${ }^{\circ}$ 62/2007 de 10 de Setembro, Regime jurídico das instituições de ensino superior, Diário da República 1stSer., No. 174,10September 2007), and Art. 6 of the Slovene Law on Higher Education of 1993 (Zakon o visokem šolstvu (ZViS), Uradni list rs, No. 67/93, 17 December 1993). The preferable way of formulation is that reflected in Art. 2(3) of the Spanish Organic Law on Universities of 2001 (Ley Orgánica 6/2001, de 21 de diciembre, de Universidades, boe No. 307, 24 December 2001): 'The activity of the university and its autonomy are based on the principle of academic freedom, which encompasses the freedom to teach, carry out research and study.'

153 Zákon 111/1998 Sb., 22 April 1998, o vysokých školách a o změněa doplnění dalších zákonů (Zákon o vysokých školách), Sbírka zákonů ČR No. 39/1998, 5388.

154 Bayerisches Hochschulgesetz (BayHSchG), 23 May 2006, gvbl. 2006, 245.

155 In the case of Italy and Portugal, he legislation contains more than mere references to academic freedom. The overall situation in these countries, however, reflects a status best described as that of 'partial compliance.' 
l'enseignement supérieur et l'organisation académique des études of 2013 (Belgium), 156 for example, solely states, in its second sentence, that 'every member of the staff of an establishment of higher education, in the exercise of his or her duties, enjoys academic freedom.' The legislation in a fourth group of he systems, those of Denmark, Greece, Hungary, Slovenia, Sweden, and the $\mathrm{uk}$, addresses academic freedom, but in a way less satisfactory than that in the previous group ('between partial and non-compliance'). There may, therefore, be a mere reference to academic freedom, simultaneously flawed in some respect or another, or there may be more structured provisions which, however, seriously fall short of the standards defined in unesco's Recommendation. Article 3(1) of the Greek Law on Structure, Functioning, Quality Assurance of Studies, and Internationalisation of Higher Education Institutions of 2011,157 for instance, briefly states that, '[i]n institutions of higher education, academic freedom in research and teaching, as well as freedom of expression and the exchange of ideas shall be guaranteed.' Article 4(3) then proceeds to state that institutions of he are to be run in terms of rules that are in compliance with certain principles, these including 'a) freedom in research and teaching,' and 'd) efficiency and effectiveness in the management of staff, resources, and infrastructure,' the two principles seemingly ranking on a par. This seems to imply the legitimacy of trade-offs between academic freedom and pure considerations of economy. Unless a situation of a clear shortage of resources prevails, considerations of 'efficiency' may never lead to limitations of academic freedom.158 To mention another example: The uk's Education Reform Act of 1988,159 in Section 202(2)(a), stipulates that 'academic staff have freedom within the law to question and test received wisdom, and to put forward new ideas and controversial or unpopularopinions.' However, the Act recognises this freedom only whilst simultaneously, and in the context of, abolishing academic tenure. In terms of Sections 202 to 204, university

156 Décret définissant le paysage del'enseignement supérieur etl'organisation académique des études, 7 November 2013, Moniteur Belge, 18 December 2013.

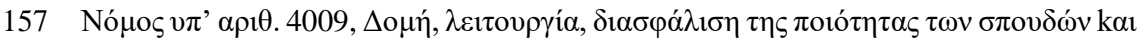

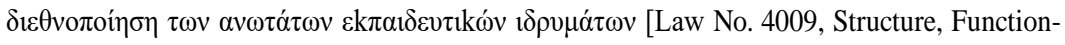
ing, Quality Assurance of Studies, and Internationalisation of Higher Education Institu-

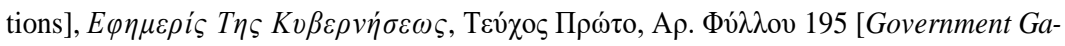
zette, 1st Iss., Ref. Sheet 195], 6 September 2011, 4255.

158 Similar formulations may be found in Section 14(1) of the Irish Universities Act, 1997 (No. 24 of 1997), and Art. 118(1) of the Romanian National Education Law of 2011 (Legea educaţiei naţionale (n 147)).

159 Education Reform Act, 1988, ch. 40. 
Country

Percentage \& Score /

20 in brackets

1. Austria, Croatia, France, North Rhine-Westphalia

$100(20)$

(Germany), Latvia, Lithuania, Slovakia

2. Germany

3. Bulgaria, Czech Republic, Finland, Bavaria

$\mathbf{8 7 , 5}(17,5)$

$75(15)$

(Germany), Ireland, Luxemburg, Romania, Spain

Average

$59,38(11,88)$

4. Belgium, Cyprus, Flanders (Belgium), Italy, Nether- 50 (10)

lands, Poland, Portugal, Wallonia (Belgium)

5. Denmark, Greece, Hungary, Slovenia, Sweden,

United Kingdom

6. Estonia, Malta

0 (0)

commissioners are to be appointed to ensure that dismissals notably for reasons of redundancy (which the Act legitimises) do not violate academic freedom. It seems that, in practice, no such commissioners have been appointed to perform that function. Altogether, the Act reflects a minimalist view of academic freedom.160 Finally, there is a fifth group of he systems (Estonia and Malta), whose he legislation contains no reference to academic freedom whatsoever ('non-compliance').

\subsection{The Protection of Institutional Autonomy in Higher Education Legislation}

he legislation should expressly provide for he institutions to be autonomous, detailing the various constituent elements of meaningful autonomy (organisational, financial, staffing, and academic), to then weave the parameters of these into the fabric of the legislative framework as a whole.

Thirty he systems having been assessed, the he Acts of 9 contain an express and adequate provision on autonomy, 20 an express, but in certain respects problematic or incomplete provision, and one a seriously deficient

160 See Barendt (n 27) 73-116, on the legal protection of academic freedom in the uk. See ibid 316-317, for a select bibliography of relevant literature on the situation in the uk. 
provision. 161 Section 6 of the Slovak Act on HigherEducation Institutions of 2002,162 for example, contains a provision on institutional autonomy by and large satisfying criteria to be considered 'adequate.' Whereas Section 2(1) states that institutions of he are separate legal entities, Section 6(1) mentions their various competences, these including those relating to internal organisation, number of students to be admitted, admission requirements and procedures, design and implementation of curricula, organisation of studies, objectives and organisation of research, conclusion and termination of employment contracts, numberof staff andstaff structure, andfinancialandassetmanagementaccordingly, broadly encompassing all four elements of autonomy. Ideally, the provision should additionally have stated - as Article 2 of the Spanish Organic Law on Universities of 2001, for instance, does - that universities have ' [a]ny other competence necessary for the appropriate fulfilment of [their] functions,' underlined that university autonomy is based on academic freedom, and pointed out that universities are accountable to society for the use of their means and resources.163 Externally, university autonomy should be buttressed by guaranteeing the inviolability of university premises - a principle long since recognised by human rights bodies. 164 Bulgaria's Higher Education Act

161 Indicator C.1.: For detail on individual state performance, see the Annex.

162 Zákony 131/2002 Z.z., 21 February 2002, o vysokých školách a o zmene a doplnení niektorých zákonov, Zbierke zákonov No. 58/2002, 1462.

163 Ley Orgánica 6/2001 de Universidades (n 152), art. 2(2), (3), (4), respectively. For some morerecentliterature on academic freedom, institutional autonomy, and self-governance in Spain, see, e.g., E. Expósito, 'Libertad de cátedra del professor universitario: Contenido y amenazas en el contexto actual de reforma del modelo de universidad pública,' Revista de Educación y Derecho No. 7 (October 2012-March 2013) 1-17, retrieved 15 May 2016, http://revistes.ub.edu/index.php/RED/article/download/5866/7627; L.A. Galindo, 'Academic Freedom and Higher Education Regulations: Spanish Universities before the European Systems,' Journal of Law and Conflict Resolution 2(2) (2010) 20-32; G. Ion and D. Castro, 'Governance in Spanish Universities: Changing Paradigms,' Journal of Hispanic HigherEducation 11(4)(2012)336-350; J.Pérez de Munguía, 'New Requirements for Higher Education, Academic Freedom and Business Interests,' Especial Educación Superior No. 10 (2009) 37-45; D. Vallespín Pérez, 'La gobernanza de la universidad: El camino hacia un "Cambio Razonable" compatibleconel respetodelaautonomíauniversitariaylalibertad de cátedra,' Revista de Educación y Derecho No. 7 (October 2012-March 2013) 1-8, retrieved 15 May 2016, http://revistes.ub.edu/index.php/RED/article/download/5862/7624.

164 The Committee on Economic, Social and Cultural Rights, supervising implementation of the icescr, has thus, following the examination of state reports, expressed its concern in cases where university campuses have been put under military guardianship, or commented that 'police presence on university campuses may infringe on the freedoms necessary for academic and cultural expression.' See Beiter (n 34) 599-600. 
of 1995,165 for example, provides in Article 19(3) that '[a]cademic autonomy shall include ... inviolability of the premises of an institution of higher education,' to then stipulate in Article 22(2) that ' $[t]$ he autonomy of an institution of higher education shall not be violated by ... the organs of public order and security entering and remaining [on] [the premises] without the consent of the academic authorities, except to prevent immanent or already commenced crime, to arrest perpetrators, and in case of natural disasters and accidents.'

Concerning the assessment of institutional autonomy in detail in terms of compliance (or not) with certain key requirements on organisational, financial, staffing, and academic autonomy (i.e. requirements, compliance with which may be considered to be highly indicative of a more general compliance with institutional autonomy), the following may be stated:166 Regarding determination of the rector: The state should not be involved in this, i.e., the rector should not be required to be appointed or the election to be confirmed by the state - also not formally at the highest executive level by the state president, the cabinet, or a minister, as this conveys an undesirable image of 'closeness' of state and he institutions. In 14 of the he systems examined, the state is involved in some way or another - usually in the stated symbolic manner-in the process.167 Regarding competence to decide on internal structures, the law should clearly not prescribe the specific faculties, departments, or institutes to be created. Article 19(1) of the University of Cyprus Law 1989 to 2013,168 for example, prescribes that there be a Faculty of Humanities and Social Sciences, a Faculty of Natural and Applied Sciences, and a Faculty of Economics and Management. The state should further not be required to set up or dissolve faculties, departments, or institutes at the request of he institutions, or to confirm their establishment/dissolution (the former being the case, e.g., in Bulgaria), and should not of itself be able to create a faculty, department, or institute within a he institution (see, e.g., Romania).169 Financial autonomy requires, inter alia, that he institutions receive state funds as a block grant (global budgets), leaving them 'free to divide and distribute their funding internally according to their needs.' Whereas 11 he systems fully comply with

165 Higher Education Act (n 151).

166 See also Estermann et al. (n 94) 20-52, for an assessment of compliance by European states in the light of the indicators addressed in this paragraph (but also other indicators).

167 Indicator C.2.1.1.: For detail on individual state performance, see the Annex.

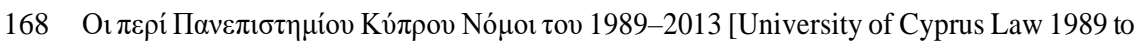

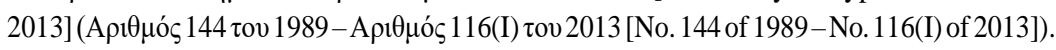

169 This is not to say that the state may not encourage and promote certain structural developments within he institutions. Indicator C.2.1.2.: For detail on individual state performance, see the Annex. 
this requirement, another 17 accept it in principle, but apply minor restrictions. It appears that only Cyprus and Greece still make use of a line-item budget, which 'pre-allocates university funding to cost items and/or activities.' 170 he institutions should further be competent to acquire funding additional to that directly allocated by the state from various sources. Notably, they should be able to perform (publiclyor privately) commissioned research against payment. Although this is actually the case in all he systems analysed,171 not all of them clearly spell this out in their primary legislation. 172 Core competences entailed by institutional autonomy should be addressed in parliamentary legislation. Staffing autonomy means that the law should lay down a minimum of detail regarding the academic positions available and the requirements for positions. In the uk, the law, in fact, refrains from regulating these matters. In Sweden, the Higher Education Act of 1992 limits itself to stipulating that '[h]igher education institutions shall employ professors ["professorer"] and senior lecturers ["lektorer"],' adding that 'each higher education institution shall itself decide which categories of teachers, apart from professors and senior lecturers, it shall employ, and on the qualifications and assessment criteria that shall apply to the appointment of such teachers.'173 Subject to observing academic freedom, entitlements relating to job security (including tenure), and fair terms of employment, there should further be no or only minor restrictions concerning the recruitment and promotion of academic staff. There should also be no requirement to the effect that the appointment of professors be performed or confirmed by the state. In France, Decree No. 84-431 of 1984174 states that ' $\mathrm{u}$ ]niversity professors shall be appointed by decree of the President of the Republic.'175 Regarding the selection of first-cycle (Bachelor) students, while respecting duties flowing from the right to education, he institutions should be granted the competence both to determine

170 Estermann et al. (n 94) 30-31. Indicator C.2.2.1.: For detail on individual state performance, see the Annex.

171 See Eurydice (n 109) 77-78.

172 Indicator C.2.2.2.: For detail on individual state performance, see the Annex.

173 Högskolelag, 17 December 1992, sfs No. 1992:1434, ch. 3, §§ 2 (1st sent.), 6, respectively. The accompanying Higher Education Ordinance of 1993 (Högskoleförordning, 4 February 1993, sfs No. 1993:100) does lay down requirements in respect of professors and senior lecturers(e.g.qualifications, assessmentcriteria, and appointmentprocedures), butthese rather give expression to broader principles applicable. See ch. 4 .

174 Décretn $^{\circ} 84-431$ du 6 juin 1984 fixant les dispositions statutaires communes applicables aux enseignants-chercheurs et portant statut particulier du corps des professeurs des universités et du corps des maîtres de conférences, jorf 8 June 19841784.

175 Indicator C.2.3.: For detail on individual state performance, see the Annex. 
the selection criteria for, and to conduct the actual selection of such students largely themselves. This is the case in 9 he systems. In 13, the responsibilities in this regard are shared between the state and he institutions. In 8, the state plays a dominant role in this respect.176 Finally, as quality control in he should essentially be left to be organised by he institutions themselves (jointly and/or severally), the requirement of having degree programmes accredited by the state or some external agency must be considered inimical to academic autonomy. Only 6 of the he systems examined dispense with the requirement of accreditation of first-cycle programmes. 177

Generally addressing the extent of government powers regarding he institutions, a reading of a state's he legislation should reflect wide competences for he institutions and a minimal measure of involvement of the state in regulating their activity. This is not to aver that the state does not holdultimate responsibility in respect of the he sector. The state should, however, merely supervise whether legal requirements have been complied with (German: 'Rechtsaufsicht'), but not review decisions on their merits (German: 'Fachaufsicht'). he institutions should be in a position to enact most regulations and take most decisions without these requiring prior approval or subsequent confirmation by the state. Chapter 7 of the Estonian Universities Act of 1995,178 dealing with 'Auditing, Supervision, and Reporting,' thus makes it clear that the state authorities do not exercise 'Fachaufsicht,' Section 53 stating that '[s]tate supervision over the legality of the activities of universities is exercised by the Ministry of Education and Research.' 179 In a handful of the he systems examined, he legislation reflects a 'lack of separation' of state and university sector.Interms of the Danish (Consolidation) Act on Universities of 2012,180 for example, the responsible minister is granted wide-ranging competences to regulate matters or to lay down general or specific rules on a variety of topics, using formulations such as: 'The minister may set maximum enrolment quotas for degree programmes' $(\S 4(5))$, 'The minister shall lay down the rules regulating the acquisition of doctoral degrees' (§ 6(2)), 'The minister shall lay down rules regarding the education provided, including tests, examinations, and grading' ( $\$ 8(1))$, or 'The minister may lay down rules on the appointment of academic staff and teachers’ (§29(3)).181 Most of the he systems examined

176 Indicator C.2.4.1.: For detail on individual state performance, see the Annex.

177 Indicator C.2.4.2.: For detail on individual state performance, see the Annex.

178 Ülikooliseadus, 12 January 1995, Riigi Teataja rt i 1995, 12, 119.

179 Emphasis added.

180 Bekendtgørelse af lov om universiteter (universitetsloven), lbk No. 960, 14 August 2014.

181 On the extensive regulation of the he sector by the Danish government in furthering he 'as a component of the national economy' and limited self-governance in Danish 
may be considered to be in 'partial compliance,' about one fifth in 'full compliance,' in respect of ensuring that their he legislation reflects restraint in granting governments powers to regulate he institutions.182

Finally, the independence of he institutions vis-à-vis private interests should enjoy a notable measure of protection in he legislation. Croatia's Act on Science and Higher Education of 2013, for example, provides that ' $[\mathrm{u}]$ niversities ... may be funded only from those sources that do not affect their independence and dignity.' 183 The University of Cyprus Law 1989 to 2013 permits chairs to be established with finance deriving from the private sector - but only 'on such conditions as shall safeguard the independence of the university from the grantor of this financial support.' 184 Laudable in itself, these statements are not enough. The statement emphasising that private funding may not compromise the independence of teaching and research in he institutions needs to be linked to an obligation of he institutions to reveal the sources and scope of private funding. It seems only one he system roughly complies with this requirement. The recent Act on the Future of Higher Education of September 2014 of North Rhine-Westphalia (Germany), 185 in Section 71 on 'Third party-funded research,' thus provides that amember of the academic staff may undertake such research, 'provided this does not prejudice the performance of other tasks of the he institution, his or her freedom in science, research, teaching, and study as well as the rights and duties of other persons' (\$ 71(2)). In Section 71a, entitled 'Transparency regarding third party-funded research,' the he Act then calls upon ' $[t]$ he rector [to inform] the public in an adequate manner about completed research projects in terms of [Section] 71(1)' (\$ 71a(1)). A similar requirement, obliging public research institutions to provide an annual overview of private financing of research conducted at such institutions, also exists in Denmark.186 This has not been provided for in terms of legislation, however, but by way of guidelines issued by the Ministry of Science,

universities, see, e.g., E. Kalpazidou Schmidt and K. Langberg, 'Academic Autonomy in a Rapidly Changing Higher Education Framework: Academia on the Procrustean Bed?,' European Education 39(4) (2007-2008) 80-94; S. Wright and R. Boden, 'Markets, Managerialism, and Measurement: Organisational Transformations of Universities in uk and Denmark,' in J.E. Kristensen et al. (eds.), University Performance Management: The Silent Managerial Revolutionat Danish Universities (djøf Publishing, 2011)79-99; S. Wright and J.W. Ørberg, 'Autonomy and Control: Danish University Reform in the Context of Modern Governance,' Learning and Teaching 1(1) (2008) 27-57.

182 Indicator C.3.: For detail on individual state performance, see the Annex.

183 Zakon o znanstvenoj djelatnosti i visokom obrazovanju (n 144), art. 107(2).

184 University of Cyprus Law (n 168), art. 21(2).

185 Hochschulzukunftsgesetz (n 143).

186 See Eurydice (n 109) 85. 
Country

Percentage \& Score /

20 in brackets

1. Finland

$75(15)$

2. United Kingdom

$\mathbf{6 7 , 5}(13,5)$

3. Croatia, North Rhine-Westphalia (Germany)

$65(13)$

4. Ireland

$\mathbf{6 2 , 5}(12,5)$

5. Austria

$60(12)$

6. Lithuania

$55(11)$

7. Estonia, Flanders (Belgium), Malta

$\mathbf{5 2 , 5}(10,5)$

8. Latvia

$\mathbf{5 0}(10)$

9. Poland

$\mathbf{4 7 , 5}(9,5)$

Average

$\mathbf{4 6 , 2 9}(9,26)$

10. Germany

$\mathbf{4 6 , 2 5}(9,25)$

11. Bulgaria, Denmark, Italy,Luxemburg, Nether-

45 (9) lands, Portugal

12. Belgium, Slovakia, Slovenia, Spain

$\mathbf{4 2 , 5}(8,5)$

13. Cyprus, Czech Republic, Romania

$40(8)$

14. France

35 (7)

15. Sweden, Wallonia (Belgium)

$32,5(6,5)$

16. Bavaria (Germany)

17. Greece

18. Hungary

Technology, and Innovation. In sum, one he system may be held to be in 'full compliance,' five in 'partial compliance,' and all the others in 'non-compliance' with the requirement of adopting legislation protecting the independence of he institutions against threats emanating from private sources.187

\subsection{The Protectionof Academic Self-Governance in HigherEducation Legislation}

Also the core elements of the right of academic self-governance should be clearly articulated in he legislation and then be given concrete shape in the various provisions on the institutional/faculty/departmental governing and

187 Seeibid, on accountability measures for private funds in he in Europe. Indicator C.4.: For detail on individual state performance, see the Annex. 
representative organs of he institutions. The right of self-governance being a central component of meaningful academic freedom, he legislation which does not articulate and operationalise its essential features does not comply with the right to academic freedom. Granted, it is in the interest of enhanced institutional autonomy to leave the regulation of many aspects in this context to institutions of he themselves; nevertheless, criteria such as those requiring academic staff to be able to elect a majority of representatives to the senate, or requiring them to be entitled to exercise 'control' over who is chosen as the rector, need to be guaranteed at the level of primary legislation. Where the uk's Education Reform Act of 1988 thus merely refers to 'the academic board of an institution,' providing no further particulars, 188 this falls short of minimum standards of compliance. The same holds true where he legislation does not deal with issues of governance at faculty/departmental level at all, as is the case, for example, in Flanders (Belgium), Ireland, or Lithuania.

Thirty he systems having been assessed, the he Acts of only 3 contain an express and adequate provision on self-governance, 12 an express, but in certain respects problematic or incomplete provision, and 15 no express provision. 189 An example of an express and adequate provision on self-governance would perhaps be that in Section 37, entitled 'General Principles of Participation,' of the German Framework Act on Higher Education in its version of 1999:190

(1) It is the right and the duty of all members of an institution of higher education to participate in the institution's self-governance. The nature and scope of participation by the various groups of members and within these groups shall vary in accordance with members' qualifications, function and responsibility, and the extent to which a matter affects them. With regard to representation on bodies made up of groups of members, professors, other academic staff ('wissenschaftliche Mitarbeiter'), students, and non-academic staff shall principally each constitute one group; all groups of members shall be represented and, as a matter of principle, in accordance with the provisions of the second sentence, participate in decision-making with a right to vote....

(2) With the exception of ex officio members, the members of a body shall be appointed or elected for a certain term of office; they shall not be bound by any instructions....

188 Education Reform Act, 1988, ch. 40, § 125(2), sched. 7A, para. 3.

189 Indicator D.1.: For detail on individual state performance, see the Annex.

190 Hochschulrahmengesetzin the version of 19January 1999, bgbl.i, at 18, last amended by Art. 2 of Law, 12 April 2007, bgbl. i, at 506. 
(3) The members of an institution of higher education shall not suffer any disadvantage by reason of their participation in the institution's self-governance.

A majority - ideally between 60 and 70 percent - of the members of the senate (or its equivalent) should be representatives of academic staff. Students should, however, also be adequately represented.191 Article 2(f) of the Italian Law of 30December2010, No. 240, on Rules on the Organisation of Universities, Academic Staff and Recruitment, as well as Governance to Enhance the Quality and Efficiency of the University System,192 for example, provides for 'the constitution of the academic senate on an elective basis': It is to 'include the rector and an elected representation of the students,' and to be 'compos[ed] by at least two thirds of academic staff ('docenti di ruolo'), at least one third of whom are heads of departments, elected in a way as to respect the different scientific-disciplinary fields of the university.' Clearly, this reflects compliance with the 60-70 percent ideal.193 Quite a number of he Acts remain vague when commenting on the composition of the senate (or its equivalent). The Estonian Universities Act of 1995 thus provides for academic staff representatives on the council of the university, notstipulating how many representatives there should be, adding that there may also be "other persons prescribed by the statutes' on the council.194Others donotmakeprovision fora senate, and contain only scant information in respect of alternative arrangements. The Flemish Decree Amending Various Decrees regarding the University of Antwerp of 1995 (Belgium) (separate decrees existing for various Flemish universities), not catering for a senate, merely states that 'the academic governing bodies include at least a college of deans, a teaching council, a research council, and a council for scientific and operational services,' to then leave all detail to be regulated by the board of governors. 195

191 Indicator D.2.1.: For detail on individual state performance, see the Annex.

192 Legge, 30 dicembre 2010, n. 240, Norme in materia di organizzazione delle università, di personale accademico e reclutamento, nonché delega al Governo per incentivare la qualità e l'efficienza del sistema universitario, Gazz. Uff. 14 January 2011, No. 10, S.O. No. 11.

193 On recent (rather delicate) developments in the sphere of governance of he institutions in Italy, see, e.g., D. Donina et al., 'HigherEducation Reform in Italy: Tightening Regulation Instead of Steering at a Distance,' Higher Education Policy 28(2)(2015)215-234.

194 Ülikooliseadus (n 178), § 14(2).

195 Decreethoudende wijziging van diverse decreten metbetrekking tot de Universiteit Antwerpen, 22 December 1995, Belgisch Staatsblad, 1 February 1996, art. 5(2). 
Rectors should be scholars coming from within the he institution they are to serve, 196 the academic staff of that institution should be able to exercise 'control' over whois chosen as the rector(for instance, by holding a majority of votes), rector and staff should govern 'co-operatively,' and the academic staff should also be able to exercise 'control' over the rector's dismissal by means of a vote of no-confidence. Although principles of 'managerial efficiency' may perhaps call for a different governance regime, the one above is that most beneficial to promoting 'the free search for truth' and is required in terms of human rights criteria, including the principles of self-governance and collegiality as enshrined in the unesco Recommendation.197 Article 14(2) of the University of Cyprus Law 1989 to 2013,198 for example, states that '[t]he rector shall be electedfromamong the professors of the university.' Clearly, the rector here is 'a scholar' from within the he institution. The assessment has shown that rectors increasingly may come from outside the institution and often it is not expressly stated that they should be academics.199 Regarding the particular manner in which rectors are chosen, the models employed in this respect in the he systems examined are highly varied.200 Accordingly, academic staff may be entitled -in a more or less direct manner-to take part in determining the rector. In terms of Article 23 of the Slovene Law on Higher Education of 1993,201 ' $[t]$ he rector shall be elected by all higher education teachers, scientific staff, and higher education employees .... Students shall also have a voting right - namely, a fifth of the votes ....' Under Article 20(2) of the Spanish Organic Law on Universities of 2001,202' ' $\mathrm{t}$ ] he rector shall be elected by the senate, or by the university community through direct elections and by universal suffrage, as indicated by the statutes of eachuniversity.' Section 10(2) of the

196 This does not mean that provision may not be made for external 'management expertise' being available torectors, e.g., throughthe appointment of appropriately qualified rectorate members from outside the he institution without voting rights.

197 See Georg Krücken, 'Lässt sich Wissenschaft managen?,' Wissenschaftsrecht 41(4) (2008) 345-358 (generally expressing doubt as to whether science and research are susceptible to 'management principles' whatsoever).

198 University of Cyprus Law (n 168).

199 Indicator D.2.2.1.: For detail on individual state performance, see the Annex.

200 Indicator D.2.2.2.: Fordetail on individual state performance, see the Annex. Apart from verifying the extent of academic staff participation, the assessment has also taken into account whether or not general principles of democratic elections/selection procedures have been complied with.

201 Zakon o visokem šolstvu (n 152).

202 Ley Orgánica 6/2001 de Universidades (n 152). 
Slovak Act on Higher Education Institutions of 2002203 stipulates that ' $[t]$ he rector shall be appointed and dismissed at the proposal of the senate ... by the President of the Slovak Republic.'204 The general trend, however, is 'to do away with' direct or indirect participation of academic staff and to have the rector appointed by a 'third body,' to wit he institution boards, many introduced in the wake of 'new university management' policies en vogue since the 1990s. Customarily, all or the majority of the members of these boards are external, representing a variety of - including government and corporate - interests. The bodies sometimes merely perform a supervisory function, but in many cases they play a decisive role in strategic decision-making.205 In terms of the Danish (Consolidation) Acton Universities of 2012, the board-there being no senate or its equivalent206-appoints the rector. Although there are alsomembers representing academic staff on the board, the majority of members must beexternalmembers, who 'have experienceinmanagement, organisation, and finance.'207 Under the Finnish Universities Act of 2009, also the board - again, no provision having been made for a senate or its equivalent - elects the rector. Academic staff is represented on the board, but as also otherpersonnel and students are represented, and at least 40 percent of board members must be 'other persons' 'with expertise in social life and the sciences,' it is not certain that members representing academic staff will hold a majority of votes. 208 In the Netherlands, the Law on Provisions concerning Higher Education and Scientific Research of 1992 envisages all members of the rectorate (college van bestuur), including the rector, to be appointed by the raad van toezicht,

203 Zákony o vysokých školách (n 162).

204 In Austria, the senate proposes candidates, but the council (consisting of external experts) then elects the rector (Universities Act of 2002 (n 145), §§ 21(1)(4), 23a, 23(3), 25(1) (5a)).InBulgaria, the general assembly, abody whichisseparatefrom theacademiccouncil (equivalent of a senate) and has a clear two-thirds majority of academic staff members, elects the rector (Higher Education Act of 1995 (n 151), arts. 27, 29(1)(4)). In Greece, the council (i.e. not the senate), with a slight preponderance of academic staff members, decides on candidates subsequently voted on directly by academic staff (Law on Structure, Functioning, Quality Assurance of Studies, and Internationalisation of Higher Education Institutions of 2011 (n 157), art. 8(16)).

205 SeeEurydice (n 109) 33-42, orEstermann et al. (n 94) 20-29, attesting to these developments, but commenting on them neutrally.

206 I.e. apartfrom academic councils, $\mathrm{PhD}$ committees, and boards of studies 'established by the rector.'

207 Universitetsloven (n 180), §§ 10(7), 12(1), (3).

208 Yliopistolaki (Lag), No. 558/2009, 24 July 2009, §§ 14(2)(7), 15(2)-(4). 
consisting of three to five external members, appointed by the minister.209 What has been stated regarding the particular manner rectors are chosen may also be observed in as far as their dismissal is concerned. Some of the he systems leave the powers in this respect to academic staff. In terms of Section 13(6) of the Hungarian Act on National HigherEducation of 2011,210 the senate may thus, by the affirmative vote of two thirds of the members, initiate the dismissal of the rector.211 In Poland, where the rector, under the Law on Higher Education of 2005,212 is either elected by an electoral body (not defined more closely) or determined by way of a competitive procedure, as specified in the statutes of a he institution, he or she may, in terms of Article 78(1) to (3), be dismissed by a three-quarter majority vote of the electoral body or a two-thirds majority of all members of the senate, as the case may be. Nevertheless, also in this respect the trend is for those he systems in which the rector is chosen by a board to grant the latter also the competence to dismiss the rector. Thus, in Denmark, Finland, or Lithuania, the board appoints/elects the rector and dismisses him orher.213

In some of the he systems assessed, the rector and the senate (or its equivalent) retain responsibility for strategic decision-making. This is so, for example, in Bulgaria, the Czech Republic, Hungary, Latvia, or Romania. In these cases, there may additionally be certain other bodies that include external experts, but these are then assigned solely advisory or supervisory powers. As has been pointed out, however, provision is increasingly made for separate boards, composed entirely or to a large extent of external members, with importantdecision-making powers in strategic matters. They are usually competent to appoint and dismiss rectors, often coming from outside the he institution. The rectors (or sometimes rectorates) may be granted far-reaching executive powers. Together, rector and board decide on issues such as internal structure, the heads of units, teaching and research strategy, budgets, and administrative set-up. It may well be asked to what extent the principles of selfgovernance and collegiality permit 'managerial' governance structures being introduced in he institutions. Strengthening the rector's (rectorate's) powers,

209 Wet van 8 oktober 1992, houdende bepalingen met betrekking tothet hoger onderwijs en wetenschappelijk onderzoek (whw), Stb. 1992, 593, ch. 9, tit. 1, arts. 9.3.1.-2., 9.7., 9.8.1.a.

210 2011, évi cciv, törvény a nemzeti felsőoktatásról, Magyar Közlöny 165, 30 December 2011, 41181.

211 On this basis, the Minister may recommend the dismissal of the rector to the President of the Republic. See Act on National Higher Education, § 64(2)(c).

212 Ustawa, z dnia 27 lipca 2005 r., Prawo o szkolnictwie wyższym, Dziennik Ustaw 2005, No. 164, Item 1365, as amended.

213 Indicator D.2.2.3.: For detail on individual state performance, see the Annex. 
or providing for a board making available external expertise and involved in strategic decision-making, would probably be permissible provided these measures are adequately counterbalanced by securing effective participatory and control rights for academic staff, to ensure the system of governance does not become 'detached' from the academic staff whom it should serve.214 It is submitted that academic staff should thus retain the power to elect the rector from among their midst and, where appropriate, express a lack of confidence in him orher.Academic staff shouldfurtherideallyhaveatleast50percentrepresentation on the board.215 In Portugal, the general council (replacing general assembly and senate) has a majority of representatives of academic staff, and at least 30 percentexternal members.216 In Lithuania, academic staff are represented by slightly lessthan 50 , namely about 45 , percent of council members, there being an equal share of external members, the final 10 percent reflecting student representation.217 The scope of academic staff representation is sometimes left ratherunclear. The governing authority in Irish universities could accordingly include up to about 75 percentexternal members. Representation of academic staff may be as low as 13 or as high as somewhat more than 50 percent. $218 \mathrm{As}$ for the University of Malta, there must be external members on the council, and, depending on the circumstances, 'academic' members would constitute between 10 and 45 percent of council members.219 In the so-called 'post-1992'

214 See Hamburgisches Hochschulgesetz case, Federal Constitutional Court of Germany (2010) (n 61), paras. 88-95 (114-118) (the court in this case, in the German context, pointing out that, where bodies such as the rector (rectorate) or dean (dean's office) are granted substantive decision-making powers that have abearing on science and scholarship, academic staff must retain effective participatory and control rights).

215 Cf. L. Elton, 'Collegiality and Complexity: Humboldt's Relevance to British Universities Today,' Higher Education Quarterly 62(3) (2008) 224-236, at 232 (stressing the need for 'a democratic form of leadership, distributed throughout an organisation, very different from the current form of top-down leadership' in he), and at 233 (emphasising that the vice-chancellor should be the 'university's first servant'). Cf. also M. Shattock, 'Re-balancing Modern Concepts of University Governance,' Higher Education Quarterly 56(3) (2002) 235-244, at 240 (arguing in support of 'moving back to a more evenly balanced approach to governance - the "shared governance" concept').

216 Lein. ${ }^{\circ}$ 62/2007, Regime jurídico das instituições de ensino superior, n 152, art. 81. For an account of more recent changes in Portuguese he, see, e.g., A. Magalhães et al., 'Governance of Governance in Higher Education: Practices and Lessons Drawn from the Portuguese Case,' Higher Education Quarterly 67(3) (2013) 295-311; R. Santiago and T. Carvalho, 'Managerialism Rhetoricsin Portuguese HigherEducation,' Minerva 50(4)(2012)511-532.

217 Mokslo ir studijų ịstatymas (n 148), art. 20(3).

218 Universities Act, 1997 (No. 24 of 1997), § 16.

219 Education Act, Act xxiv of 1988 (Cap. 327, Laws of Malta, 1988), arts. 74(10), 76. 
English universities, at least half of the 12(13) to 24(25) members of the governing body must be 'independent.' Up to two members may be teachers at the institution nominated by the academic board. There are further one tonine co-opted members among the members, who could potentially be teachers at the institution.220 It may, however, also be clear that all the members of the board are to be external experts. In the University of Luxemburg, all seven members of the governing council are external members, at least four of which 'must exercise or have exercised university responsibilities.'221 An arrangement in terms of which there are (mainly) external members on the board, but academic staff are in a position to determine at least half of these - as is the case, for instance, in Austria222 - would perhaps still pass muster, but only at the level of 'partial compliance.'223

The above enquiry has been replicated at the level of the units of he institutions (faculties and departments). First of all, have collegial bodies been provided for at faculty/departmental level?224 Do these bodies adequately representacademic staff?225Further, aredeans/heads of departmentsrequired tobe scholars from within their respective unit, at any rate their institution?226 Do academic staff exercise 'control' over who is chosen as the dean/head of department, or do they exercise certain, but more restricted rights of participationinthisrespect-or,infact, noneatall?227Likewise, are they able toexercise 'control' over the dean's/head of department's dismissal by means of a vote of no-confidence, or have they been accorded qualified or no rights of participation in this regard.228 The criteria of compliance and the rationale underlying these resemble those at the institutional level and need not be repeated here. A number of the he systems assessed (Austria, Flanders (Belgium), Wallonia (Belgium), Estonia, Finland, Hungary, Ireland, Latvia, Lithuania, the Netherlands, Portugal, Sweden, and the uk) fail to regulate the right of selfgovernance at the unit level whatsoever or they do so in a clearly insufficient

220 Education Reform Act, 1988, ch. 40, sched. 7A, para. 3 (composition of governing body).

221 Loi du 12 août 2003 portant création de l'Université du Luxembourg, MEMORIAL Journal Officiel du Grand-Duché de Luxembourg A - No. 149, 6 October 2003, 2989, art. 19(1) (the government proposes candidates, the Grand Duke appoints them).

222 Universitätsgesetz ( 145$), \S 21(6)$ (50\% of the council members 'determined' by academic staff (elected by the senate), $50 \%$ appointed by the government).

223 Indicator D.2.3.: For detail on individual state performance, see the Annex.

224 Indicator D.3.1.1.: For detail on individual state performance, see the Annex.

225 Indicator D.3.1.2.: For detail on individual state performance, see the Annex.

226 Indicator D.3.2.1.: For detail on individual state performance, see the Annex.

227 Indicator D.3.2.2.: For detail on individual state performance, see the Annex.

228 Indicator D.3.2.3.: For detail on individual state performance, see the Annex. 
Table 4 Country Ranking-Protection of Academic Self-Governance in he Legislation

Country

1. Bulgaria

2. Croatia

3. Cyprus, North Rhine-Westphalia (Germany), Poland, Romania, Slovakia

4. Germany

5. Bavaria (Germany), Spain

6. Portugal

7. Czech Republic, Slovenia

8. Greece, Latvia

9. Austria, Hungary

Average

10. Wallonia (Belgium), Italy

11. Belgium

12. Flanders (Belgium)

13. Denmark, France

14. Lithuania, Luxemburg, Malta

15. Netherlands

16. Estonia

17. Finland, Ireland, Sweden

18. United Kingdom
Percentage \& Score /

20 in brackets

$\mathbf{7 2 , 5}(14,5)$

70 (14)

$\mathbf{6 2 , 5}(12,5)$

$\mathbf{6 1 , 2 5}(12,25)$

60 (12)

$\mathbf{5 7 , 5}(12,5)$

$55(11)$

$\mathbf{5 2 , 5}(10,5)$

45 (9)

$42,99(8,6)$

$40(8)$

$37,5(7,5)$

35 (7)

$\mathbf{3 2 , 5}(6,5)$

$30(6)$

$\mathbf{2 7 , 5}(5,5)$

$22,5(4,5)$

$15(3)$

0 (0)

way. As has been underlined, although the particular manner governance at the unit level is concretised should as far as possible be left to he institutions themselves to decide, human rights aspects of self-governance at this level need to be provided for in primary legislation.

\subsection{The Protectionof Job Security (including 'Tenure')in Relevant Legislation}

The legal framework governing the duration of contracts of service of academic staff in he at post-entry levels (i.e. following any stage of doctoral employment) should envisage permanent contracts/commencement on a tenure-track. he systems whose laws are in compliance with this requirement 
include, amongstothers, Flanders(Belgium),Bulgaria,orFrance.229Article48(1) of the Bulgarian Higher Education Act of 1995230 thus provides that ' $[t] h e$ academic staff in higher education institutions shall comprise: 1 . for habilitated teachers - associate professor and professor; 2. for non-habilitated teachers - assistant and senior assistant,' Article 54(1) further stating that '[t]he positions under [Article 48(1)], except for the position of "assistant," shall entail a contract of service for an indefinite period.' The legal framework of some of the he systems assessed-for example that in place in Luxemburg or Poland - leaves it to he institutions themselves to decide whether or not to offer permanent contracts. In these cases, the use of fixed-term contracts may be subject to fairly strict limitations as to legitimate cases of use, maximum number of successive contracts, and their maximum cumulated duration. Article 35(1) of the Law of 12 August 2003 on the University of Luxemburg231 thus states that the employment of enseignants-chercheurs may befixed-term or permanent. Although the general rule under the Code du Travail is that fixed-term contracts may only be concluded for 'the execution of tasks which are specific and not durable' (Art. L. 122-1(1)), these may expressly be concluded with enseignants-chercheurs of the University of Luxemburg(Art.L.122-1(3) (1)). The lattercontracts are renewable (also more than twice, this constituting the limit otherwise), 232 but there is an overall limit of 60 months (including renewals)(ordinarily thisis 24 months)for which theymaybeenteredinto. 233 The use of fixed-term contracts may, however, also be subject to rather lax requirements. In Poland, academic staff are either appointed (entailing higher employment security) - applicable only if the academic title of profesor has been awarded - or engaged under contracts of employment governed by the Labour Code of 1974.234 Appointments 'shall be for an indefinite or definite period of time.'235 Ordinary employment contracts may likewise be permanent or fixed-term. Although the legislator has now effected changes, theonly restriction hitherto applicable to the latter contracts has been that they could not be concluded more than twice.236 They could be concluded for any period of

\footnotetext{
229 Indicator E.1.1.: For detail on individual state performance, see the Annex.

230 Higher Education Act (n 151).

231 Loi portant création de l'Université du Luxembourg 2003 (n 221).

232 Code du Travail, art. L. 122-5(1), (3)(1).

233 Ibid art. L. 122-4(1), (4).

234 Prawo o szkolnictwie wyższym 2005 [Law on Higher Education 2005] (n 212), art. 118(1).

235 Ibid art. 121(2).

236 Ustawa, z dnia 26 czerwca 1974 r., Kodeks pracy [Act, 26 June 1974, Labour Code], Dziennik Ustaw 1974, No. 24, Item 141, art. 251, § 1 (as prior to the 2016 amendments).
} 
time.237Whereas cases such as that of Luxemburg should beheld to constitute instances of 'partial compliance,' those in the nature of the former Polish situation should be considered cases of 'non-compliance.' Clearly also 'in non-compliance' are he systems, whose legal framework expressly envisages fixed-term contracts for academic staff at post-entry levels, even those with senior positions (associate or full professors), there being little or no prospect of permanent contracts being concluded. The Estonian Universities Act of 1995,238 in Section 39(1), thus states that ' $[t]$ he positions of regular teaching and research staff at a university shall be filled for up to five years by way of public competition with equal conditions for all participants ....' It is further stipulated, in Section 391(1), that ' $[t]$ he successive conclusion of fixedterm employment contracts with teaching or research staff shall not cause the employment relationship to become one for an unlimited term.' In fact, '[a]n employment contract for an unlimited term shall [only] be concluded with a person who has been employed in the same university and has worked as a professor for at least eleven years, following evaluation under conditions and procedures established by the council of the university' ( $\$ 391(2)) ! 239$

The situation in practice regarding the duration of contracts of service in many instances is not as one would expect it to be in terms of the letter of the law in force. 240 In some cases, protective legislation does not actually have a

237 As from 2016 onwards, there may not be more than two renewals, and the overall period may not exceed 33 months (amendments to the Labour Code of 25 June 2015). These changes could not yet be taken into consideration for purposes of the present assessment.

238 Ülikooliseadus (n 178).

239 See also European Commission, Commission Asks Estonia to Apply the Fixed-Term Employment Directive Fully in Academia and the Arts (24 October 2012), retrieved 15 May 2016, http://ec.europa.eu/social/main.jsp?langId=de\&catId=157\&newsId=1707\&further News=yes (reporting that the European Commission has asked Estonia to provide fixedterm staff in universities with protection against successive fixed-term employment contracts in accordance with Council Directive 99/70, 1999 o.j. (L 175) 43 (ec) (Directive concerning the Framework Agreement on Fixed-Term Work Concluded by etuc, unice, and ceep), this establishing a framework to prevent abuse arising from the use of successive fixed-term employment contracts or relationships). Legislative provisions similar to those in Estonia exist in Croatia, Latvia, and Slovakia.

240 Indicator E.1.2.: For detail on individual state performance, see the Annex. Various sources of information have been used to assess compliance regarding this indicator, e.g., G. Ates and A. Brechelmacher, 'Academic Career Paths,' in U. Teichler and E.A. Höhle (eds.), The Work Situation of the Academic Profession in Europe: Findings of a Survey in Twelve Countries (Springer, 2013) 13-35, or Idea Consult et al., Supportfor Continued Data Collection and Analysis Concerning Mobility Patterns and Career Paths of Researchers (Final Report more2, Prepared for European Commission, Research Directorate-General, 
protective effect. In Germany, theprovisionsof the Acton Fixed-Term Contracts of Employment in Science of 2007,241 intended to restrict the use of fixed-term contracts, allowing these only where staff are financed primarily out of third party funds, are being abused by converting ordinary academic positions into third party-funded positions.242 In othercases, alegal framework not inaccordance with required standards yet does not prevent a high level of protection in practice. In the Netherlands, for instance, academic staff are civil servants under the Central and Local Government Personnel Act.243 Actual protective standards, however, are only provided for at thelevel of more 'volatile' secondary legislation and collective labour agreements. 244 In practice, about 75 percent of academic staff either have permanent contracts or fixed-term contracts with long-term prospects. 245 In the $u k$, despite the absence of parliamentary legislation on the matter, almost 90 percent of academic staff either have permanent contracts or fixed-term contracts with long-term prospects. 246

The he legislation of roughly a third of the he systems assessed contains provisions prohibiting dismissals of academic staff on operational grounds (restructuring, down-sizing, reorganisation, or economic difficulties) orlaying down some protective standards for cases where such dismissals take place.247 Ireland and Portugal expressis verbis require academic staff to enjoy 'tenure.' Section 25(6) of the Irish Universities Act of 1997 insists that ' [a] university ... shall provide for the tenure of officers.' 248 Article 50 of the Portuguese Law

Brussels, August 2013), retrieved 15 May 2016, http://ec.europa.eu/euraxess/pdf/research_ policies/more2/Final\%20report.pdf.

241 Gesetz über befristete Arbeitsverträge in der Wissenschaft (Wissenschaftszeitvertragsgesetz-WissZeitVG), 12 April 2007, bgbl. I, at 506.

242 See, e.g., A. Sartor, 2013, 'Forschen auf Zeit: Wissenschaftliche Mitarbeiter sind meistens befristet angestellt - warum eigentlich?,' Zeit Online, 18 June 2013, retrieved 15 May 2016, http://www.zeit.de/campus/2013/04/wissenschaftliche-mitarbeiter-befristung.

243 Ambtenarenwet van 12 december 1929, bwbr0001947.

244 See Algemeen Rijksambtenarenreglement, besluit van 12 juni 1931, bwbr0001950, ministeriële regelingen (ministerial regulations), arts. 5(1), (2) (providing for recourse to fixedterm contracts by way of exception only), 6(6) (imposing limits on the conclusion of fixed-term agreements), and Collectieve arbeidsovereenkomst (cao) Nederlandse Universiteiten, 1 januari 2011 tot en met 31 december 2013 (collective labour agreement), arts. 2.2(1) (exceptional nature of fixed-term contracts), 2.3(1), (7) (limits on the conclusion of fixed-term contracts).

245 See Ates and Brechelmacher (n 240) 27 (figures for 2007/08).

246 See ibid 27 (figures for 2010).

247 Indicator E.2.1.: For detail on individual state performance, see the Annex.

248 Universities Act, 1997 (No. 24 of 1997). See Section 3(1) for a definition of the term 'officer.' 
on the Legal Status of Institutions of Higher Education of 2007249 states that, ' $[\mathrm{s}] \mathrm{o}$ as to guarantee their scientific and pedagogical autonomy, higher education institutions must have a permanent staff of teachers and researchers benefiting from an enhanced level of employment stability (tenure).' In the case of Greece and Poland, dismissals of certain academic staff for reasons of redundancy arenotallowedorrestricted.InGreece, professorsmayonlybedismissed for reasons of a criminal conviction, a grave disciplinary breach, illness or disability, or professional incompetence.250 In Poland, those 'appointed' to their position and holding the title of 'professor' may generally not be dismissed for reasons of redundancy.251 In the case of Austria, Finland, and the uk, he legislation contains provisions to the effect that a contract of service may not be terminated because a member of the academic staff has exercised his/her freedom to teach or carry out research, this precluding 'redundancy' serving as a pretext for 'getting rid of' certain members of staff.252 The Bulgarian Higher Education Act of 1995,253 in Article 58(1)(3), countenances dismissals for reasons of redundancy, but only if there are no opportunities for reallocation to another department or re-qualification in a related discipline. In a number of he systems, all or at any rate senior members of the academic staff are civil/ public servants/public sector workers, i.e. not 'ordinary' employees in terms of private law. This status may entail their dismissal on operational grounds being excluded (even where he legislation does not expressly affirm such protection). Such status entailing prohibition of dismissal exists in Flanders (Belgium), Wallonia (Belgium), Croatia, Cyprus, Bavaria (Germany), North Rhine-Westphalia (Germany), Greece, Ireland, Italy, Portugal, and Spain. In the case of France, Hungary, the Netherlands, and Slovenia, academic staff who are civil servants may (at leastin theory) be dismissed on operational grounds. 254 Concluding the comments on this indicator, it may be noted that the he legislation (in the form of parliamentary enactments) of none of the he systems assessed contains a full-fledged provision generally prohibiting

249 Lei n. ${ }^{\circ}$ 62/2007, Regime jurídico das instituições de ensino superior (n 152).

250 This is, in fact, provided for in terms of the Greek Constitution 1975. See art. 16(6).

251 Prawo o szkolnictwie wyższym 2005 [Law on Higher Education 2005] (n 212), arts. 118(1), 123-128. Art. 125 does, however, provide for termination 'on other compelling grounds.'

252 Universitätsgesetz 2002 (n 145), § 113 (Austria); Yliopistolaki 2009 (n 208), §32 (Finland); Education Reform Act, 1988, ch. 40, §§ 202-204 (uk).

253 Higher Education Act (n 151).

254 See C. Demmke and T. Moilanen, The Future of Public Employment in Central Public Administration: Restructuring in Times of Government Transformation and the Impact on Status Development (Study Commissioned by the Chancellery of the Prime Minister of the Republic of Poland, November 2012) 49, retrieved 15 May 2016, http://www.eupan.eu/ files/repository/2013021293522_Study_The_future_of_public_employment.pdf. 
dismissals on operational grounds, and providing adequate protection requiring the consideration of alternatives, the observance of suitable priority criteria, the following of a formalised procedure, and the guarantee of procedural safeguards - in those exceptional cases where they may take place.

To the extent that he legislation does not address the issue of the termination of contracts of service on operational grounds, recourse needs to be had to the provisions of 'ordinary' civilservice/labourlaw. These may provide adequate, some, or insufficient protection to academic staff in this regard. Adequate protection would imply that the notice of termination clearly state the grounds of termination, that alternatives to termination (such as transfer to another similar position within the institution, transfer to another similar position in another institution, or retraining) be considered, and that, where termination cannot be avoided, suitable priority criteria (e.g. length of service or age) be followed. On the whole, 12 he systems provide a rather high level of protection in this context, 11 a medium, and 7 a low level of protection. 255

Adequate provision for advancement of academic staff to a higher position based on anobjective assessment of competenceshouldfurtherbemade. Some of the he systems assessed do so through a tenure-track system.256 Article v.29 of the Flemish Codification of the Decretal Provisions concerning Higher Education of 2013(Belgium)257 thus provides for a tenure-track system (which is optional for universities, however), in terms of which a 'docent' may, following a positive evaluation of his/her performance, be promoted to the position of 'hoofddocent.' Similarly, Austria and the Netherlands provide for tenure-track systems entailing promotion following positive evaluation. In Austria, the

255 Indicator E.2.2.: For detail on individual state performance, see the Annex. Various sources of information have been used to assess compliance regarding this indicator, e.g., Organisation for Economic Co-operation and Development, oecd Employment Outlook 2014 (oecd, 2014), retrieved 15 May 2016, http://www.keepeek.com/Digital -Asset-Management/oecd/employment/oecd-employment-outlook-2014_empl_outlook -2014-en\#page1, or legislative texts as found in the ilo Employment Protection Legislation Database - EPLex, retrieved 15 May 2016, http://www.ilo.org/dyn/eplex/termmain. home?p_lang=en, or on the websites of national governments.

256 See H.-J. Schiewer et al., Tenure and Tenure Track at leru Universities: Models for Attractive Research Careers in Europe (League of European Research Universities, Advice Paper No. 17, September 2014), retrieved 15 May 2016, http://www.leru.org/files/publications/ LERU_AP17_tenure_track_final.pdf, for an overview of tenure-track systems (most of them not based on parliamentary legislation) in a number of European countries.

257 Codificatie van 11 oktober 2013 van de decretale bepalingen betreffende het hoger onderwijs, as endorsed by Decreet tot bekrachtiging van de decretale bepalingen betreffende het hoger onderwijs, gecodificeerd op 11 oktober 2013 (1), 20 December 2013, Belgisch Staatsblad, 27 February2014. 
system envisages advancement from assistant to associate professor. In the Netherlands, the applicable provisions lay down a potential procedure on which advancement of academic staff in he may be based. However, whereas the Flemish tenure-track system has its origin in parliamentary legislation, the systems of Austria and the Netherlands have been provided for in collective labour agreements only.258 Other he systems create entitlements relating to promotion otherwise than through a tenure-track system. Article 18(3) of the Greek Law on Structure, Functioning, Quality Assurance of Studies, and

Table 5 Country Ranking - Protection of Job Security (including 'Tenure') in Relevant Legislation

Country

1. Greece

2. France

3. Italy

4. Spain

5. Ireland, Portugal, Slovenia

6. Flanders (Belgium), Cyprus

7. Bulgaria

8. Belgium

9. Wallonia (Belgium), Malta, Sweden

10. Bavaria (Germany), North Rhine-Westphalia (Germany), Germany, Hungary

Average

11. Netherlands

12. Denmark, Romania, United Kingdom

13. Austria, Lithuania, Poland

14. Croatia

15. Luxemburg

16. Finland, Latvia

17. Czech Republic

18. Estonia, Slovakia
Percentage \& Score /

20 in brackets

$100(20)$

$\mathbf{7 7 , 5}(15,5)$

$\mathbf{5 7 , 5}(11,5)$

$\mathbf{5 5}(11)$

$\mathbf{5 2 , 5}(10,5)$

$50(10)$

47,5 $(9,5)$

46,25 $(9,25)$

$\mathbf{4 2 , 5}(8,5)$

40 (8)

$37,28(7,46)$

35 (7)

$27,5(5,5)$

25 (5)

$22,5(4,5)$

$17,5(3,5)$

15 (3)

10 (2)

$\mathbf{7 , 5}(1,5)$

258 See the Kollektivvertrag für die ArbeitnehmerInnen der Universitäten (2013), § 27(5), for Austria, and the Collectieve arbeidsovereenkomst (cao) Nederlandse Universiteiten, 1 januari2011 toten met 31 december 2013, art. 6.5a, for the Netherlands, respectively. 
Internationalisation of Higher Education Institutions of 2011259 lays down that 'assistant and associate professors have the right to request a vacancy at the next level after a stay at the rank they hold after six and four years, respectively .... In this case, the vacancy notice is mandatory .... If assistant and associate professors are not promoted to the next level, they have the right to request a re-announcement of the position after a lapse of at least three years following the decision not to be promoted.' At the very opposite end of the scale are he systems such as that of Lithuania, Article 65(4) of its Law on Higher Education and Research of 2009260 providing that '[p]ersons shall gain access to a higher position in the teaching or research staff by way of an open competition [only].' Altogether, he systems fail to adequately deal with the issue of advancement. Only the Greek arrangements have been considered to bein 'full compliance,' those of 16otherhe systems in 'non-compliance.'261

\subsection{The LegalProtection of the RighttoAcademic Freedomin Europe: Overall CountryRanking}

Table 6 on the following page depicts the overall country ranking for the legal protection of the right to academic freedom in Europe. For each country, it adds up the scores out of twenty for each of the five main categories of assessment (1. ratification of international agreements and constitutional protection, 2. express protection of academic freedom in he legislation, 3. protection of institutional autonomy inhe legislation, 4. protection of academic self-governance in he legislation, and 5. protection of job security (including 'tenure') in relevant legislation), to arrive at a score out of hundred (a percentage mark). On the basis of the latter, the country's position in the ranking is determined.

\section{Analysis and Observations: The State of Health of the Legal Protection of the Right toAcademic Freedomin Europe}

The assessment has shown that by and large the 28 eu Member States formally ascribe to the value of academic freedom. In general, they have ratified relevant international agreements providing protection to the right to academic freedom (iccpr, icescr, echr, etc.) and give recognition to the right (or related rights) at the constitutional level. Table 1 reflects countries to have scored an average of 78 percent in this category. Also at the level of

259 Law onStructure, Functioning, Quality Assurance of Studies, and Internationalisation of Higher Education Institutions of 2011 (n 157).

260 Mokslo ir studijų įstatymas (n 148).

261 Indicator E.3.: For detail on individual state performance, see the Annex. 
1. North Rhine-Westphalia (Germany)

2. Croatia

3. Spain

4. Bulgaria

5. Germany

6. Austria

7. France

8. Portugal

9. Slovakia

10. Latvia

11. Lithuania

12. Bavaria (Germany)

13. Italy

14. Greece

15. Finland

16. Poland

17. Romania

18. Cyprus

Average

19. Ireland, Slovenia

20. Czech Republic, Flanders (Belgium)

21. Belgium

22. Luxemburg

23. Wallonia (Belgium)

24. Netherlands

25. Sweden

26. Denmark

27. Hungary, Malta

28. United Kingdom

29. Estonia

\section{$71 \mathrm{~B}$}

$69 \mathrm{C}$

66,5 C

65,5 C

64,5 C

63,5 C

$63 \mathrm{C}$

$61 \mathrm{C}$

$60,5 \mathrm{C}$

$60 \mathrm{C}$

59,5 D

58 D

57,5 D

55,5 D

$55 \mathrm{D}$

54,5 D

53,5 D

$53 \mathrm{D}$

$52,79 D$

52,5 D

51,5 D

49,25 E

47,5 E

$47 \mathrm{E}$

$44 \mathrm{E}$

39,5 F

38,5 F

$36 \mathrm{~F}$

$35 \mathrm{~F}$

$34 \mathrm{~F}$

he legislation, academic freedom enjoys express recognition in most he systems, Table 2 showing that an average of 59 percent compliance was achieved in this category. There are, however, some he systems - those of Denmark, Estonia, Greece, Hungary, Malta, Slovenia, Sweden, and the uk - whose he 
legislation does not, or not adequately, refer to academic freedom. Whereas all he systems, in a more or less satisfactory manner, expressly provide for the autonomy of institutions of he in their he legislation (Indicator C.1.), rights of self-governance of academic staff (Indicator D.1.), and tenure in the sense ofemploymentstability (IndicatorE.2.1.) are accordedexpress recognition in suchlegislation in 15 and 8 he systems, respectively, with arating of 'full compliance' having been awarded in only three cases/one case, respectively.

If one turns to analysing the way aspects of the right to academic freedom have been concretised in the he and other legislation of the states concerned, it will be noted that performance levels are far less satisfactory than those identified inview of thatright's formal protection. The averagescore forinstitutional autonomylies at 46 percent(Table 3 ), thatforacademic self-governance below that at 43 percent (Table 4), and that for job security (including 'tenure') at a mere 37 percent (Table 5). Many a commentator would perhaps disagree and considerinstitutional autonomy toenjoy a higher level of legal protection than borne outhere. However, as has been stressed above, institutional autonomy in the context of this study means institutional autonomy as limited by academic freedom and human rights. he institutions in many of the he systems assessed do possess wide competences to include external members in their governing bodies, to levy and decide on the amount of study fees (study fees generally contradicting Article 13(2)(c) icescr), to dismiss academic staff for reasons of 'redundancy,' and to freely engage in collaborative activities with private industry to acquire funding subject to only limited public control. Such unbridled powers, however, are not concomitant with institutional autonomy rather, they expose a misinterpretation of the concept! Table 3 shows Finland and the uk to be the top performers in the category 'institutional autonomy.' At the bottom of the table is Hungary, Hungarian he legislation generally reflecting a paternalistic role of the state in regulating he.

The autonomy of an institution of he can, moreover, not be divorced from the guarantee of academic self-governance. he institutions that possess wide powers, but in which the academic community - encompassing academic staff, but also students - does not retain the competence to sufficiently participate in the taking of decisions directly or indirectly having a bearing on science and scholarship, can at most be seen to be nominally autonomous and they are certainly not in accordance with the standards of the unesco Recommendation. The assessment has revealed that the he legislation of European states inadequately protects the right of 'sufficient participation,' which is increasingly being eroded by promoting an 'alternative model.' At the institutional level, states achieve an average score of just 49,4 percent (the percentage average of the sum of the scores for indicators underD.2.), and, 
atfaculty/departmentallevel (where alarge-scale failure to regulate aspects of self-governance whatsoever by way of legislation may be observed), merely 35 percent (the percentage average of the sum of the scores for indicators under D.3.) for their implementation of the right to self-governance. Legislative changes adopted in the past five to ten years, in some instances also before that, have accordingly entailed the powers of senates (or their equivalents) having been restricted to purely academic matters (or worse, senates (or their equivalents) having been replaced by 'committees of academics,' often presided over by non-elected managers), the introduction of institutional boards with strategic decision-making powers, composed of various stake-holders, many external and representing government and corporate interests(academic staff, in the worst case, not being represented and having no control over candidates appointed), and the strengthening of the executive powers of rectors and deans/departmental heads, who frequently come from outside the institution, academic staff not being able to adequately participate in their election or dismissal. But also generally, governance structures in he institutions increasingly exclude academics, recruiting instead a new 'caste' of personnel with administrative, but little or no subject-specific academic expertise, responsible for 'managing' he institutions and their affairs.262 Interestingly, states such as Bulgaria, Croatia, and Romania that are not yet in the tow of Bologna reforms perform best in the category of 'self-governance.' The uk, a top performer on 'institutional autonomy,' fares worst on 'self-governance.'

Institutional autonomy is also limited by the requirements of security of employment, including 'tenure or its functional equivalent, where applicable.' he institutions in Europe, however, in 'managing' their affairs, have come to view their academic staff as strategic capital. If staff are not 'useful' in accordance with 'strategic objectives' anymore, they forfeit their right to remain with the he institution concerned. The assessment has shown that states achieve

262 In this vein with regard to universities in the uk, Dr. M. Waring (Cardiff Metropolitan University), researcher on human resource management in he and senior tradeunion official, in a talk on 'Management technologies and academic freedom,' delivered on 9 September 2014 at unike (Universities in the Knowledge Economy) Workshop 4: Management Technologies, held from 8-10 September 2014 at the University of Roehampton, London. See also T. Docherty, 'Thomas Docherty on Academic Freedom,' Times Higher Education, 4 December 2014, retrieved 15 May 2016, https://www.timeshigher education.co.uk/features/thomas-docherty-on-academic-freedom/2017268.article (holding that ' $[\mathrm{m}]$ anagerial fundamentalism has taken hold in universities, with scholars viewed as resources that must be controlled'). See further P. Taylor, 'Humboldt's Rift: Managerialism in Education and Complicit Intellectuals,' European Political Science 3(1) (2003) 75-84 (referring to the phenomenon of 'supinely acquiescent academics,' who disagree with 'managerialism,' but do not 'speak out'). 
an average score of just 47,3 percent (the percentage average of the sum of the scores for indicators under E.1.) and merely 43,8 percent (the percentage average of the sum of the scores for indicators under E.2.) for the assurance of stable employment in terms of the duration of contracts of service and the protection against dismissals on operational grounds, respectively. While the premise in academia used to be that 'the university does not employ academics, it facilitates their work,' this notion appears to be absent in he institutions today. As Boden and Epstein point out, '[a] facilitator provides resources and eases one's path towards one's goals. But an employer regards employees as resources - along with otherinputs - to be managed to achieve organizational objectives.263 The 'he institution as facilitator' notion is that underlying the unesco Recommendation and its conception of the right to academic freedom. Statesin Southern and WesternEurope(Greece, France, Italy, Spain, and Portugal) are among the 'top' performers in the category 'security of employment,' only 7 states altogether, however, achieving a score above 50 percent.

Finally, turning to Table 6 showing the overall country ranking on the legal protection of the right to academic freedom in accordance with the assessment, it will have to be conceded that it is difficult to identify clear trends. One he system-that of North Rhine-Westphalia(Germany)-scored more than 70, namely 71 percent (Grade B), eight between 60 and 69,9 percent (Grade C),264 twelve between 50 and 59,9 percent (Grade D),265 three between 40 and 49,9 percent (Grade E),266 and six between 30 and 39,9 percent (Grade F).267 he systems that used to be steeped in the Humboldtian tradition with its emphasis on Lernfreiheit (freedom of study), Lehrfreiheit (freedom of teaching), Forschungsfreiheit (freedom of research), and further the Einheit von Forschung und Lehre (the unity of research and teaching) - those of Austria, Bavaria (Germany), and North Rhine-Westphalia (Germany) - still seem to

263 R. Boden and D. Epstein, 'A Flat Earth Society? Imagining Academic Freedom,' Sociological Review 59(3) (2011) 476-495, at 481 (citing M. Waring, 'Labouring in the Augean Stables? $\mathrm{hrm}$ and the Reconstitution of the Academic Worker,' International Journal of Management Concepts and Philosophy 3(3) (2009) 257-274 in this respect).

264 In the order of performance: Croatia (69\%), Spain (66,5\%), Bulgaria $(65,5 \%)$, Austria (63,5\%), France (63\%), Portugal (61\%), Slovakia (60,5\%), Latvia (60\%).

265 In the order of performance: Lithuania (59,5\%), Bavaria (Germany) (58\%), Italy (57,5\%), Greece (55,5\%), Finland (55\%), Poland (54,5\%), Romania (53,5\%), Cyprus (53\%), Ireland (52,5\%), Slovenia (52,5\%), Czech Republic (51,5\%), Flanders (Belgium) (51,5\%).

266 In the order of performance: Luxemburg (47,5\%), Wallonia (Belgium) (47\%), Netherlands $(44 \%)$.

267 Inthe orderof performance: Sweden(39,5\%), Denmark(38,5\%), Hungary (36\%), Malta (36\%), United Kingdom (35\%), Estonia (34\%). 
benefit from thisinterms of theirpositionintheoverall ranking.268Thehe systems of Southern and WesternEurope-those of Cyprus, France, Greece, Italy, Portugal, and Spain-also appear in the upper half of the table. The he systems of the Beneluxstates-thoseof Flanders(Belgium), Wallonia(Belgium), Luxemburg, and the Netherlands-feature in the lowerhalf of the table. So do those of Scandinaviancountries,i.e.thehesystemsof Denmark,Finland,andSweden.269 Also the he systems of Anglophone Europe - those of Ireland, Malta, and the uk-are found in this part of the table. The picture is ratherdiffuse for the Baltic states, asitisforcountriesof Eastern Europe. Thehe systemsof Latviaand Lithuania lie on positions ten and eleven, respectively, but that of Estonia on place 28. Croatialands on the second place and Slovenia on the 19th; Bulgaria on the fourthplaceand Romaniaonthe 17th; Slovakiaontheninthplaceandthe Czech Republiconthe20th;Polandonthe16thplaceandHungaryonthe27th.

The overall average lies at 52,8 percent - and demonstrates that the state of the legal protection of the right to academic freedom in Europe is one of 'illhealth.' This being disappointing in itself, what is a matter of greater concern is that, when compared to the situation that existed prior to the changes in he legislation effected during the last ten or more years in the states assessed, a downward trend in protection levels may be observed.270 The concept of institutional autonomy is increasingly being misconstrued as autonomy not subject to the requirements of academic freedom, self-governance, and security of employment, including 'tenure.' Self-governance itself has, at all levels in he institutions, largely become eroded. The same may be stated to be the case with regard to employment security, including 'tenure,' of academic staff. Although the various changes may in some instances be the result of 'suboptimal legislative draftsmanship skills' (this might perhaps be so for Estonia, for example), they usually are part of a deliberate reform agenda for the he sector implemented by states in Europe.

268 See M.G. Ash, German Universities: Pastand Future. Crisisor Renewal? (Berghahn Books, 1997) [German transl.: Mythos Humboldt: Vergangenheit und Zukunft der deutschen Universitäten (Böhlau, 1999)], on the Humboldtian tradition in Germany. See P. Josephson et al. (eds.), The Humboldtian Tradition: Origins and Legacies (Brill, 2014), for a critical examination of the relevance of Humboldtian ideals in modern he.

269 For a discussion of academic freedom and institutional autonomy in the Scandinavian countries, see, e.g., T. Nokkala and A. Bladh, 'Institutional Autonomy and Academic Freedom in the Nordic Context: Similarities and Differences,' Higher Education Policy 27(1) (2014) 1-21.

270 This has become apparent when, in the course of examining the he legislation of the states concerned, present laws were compared with those existing prior to the laws in operation now. 


\section{Violations of the Right to Academic Freedom and the Right to Education}

The academic community has traditionally been - and in many parts of the world continues to be - a particularly vulnerable target of direct state repression.271 InEurope, however, it is nowadays rather sources of a different nature from which direct threats to academic freedom emanate, the state having become a (seemingly innocent) actor in the background. The state has assigned he institutions fairly wide-reaching powers (as it were, delegated many of its powers to these institutions). In practice, this has had the effect that he institutions themselves have become direct violators of academicfreedom. Research funding bodies are yet another source of peril to academic freedom. It may hence be asked whether the system en vogue today of research funding having tobe appliedforinternally, orexternally through 'independent' research councils/foundations, etc., on a competitive basis for virtually all research projects, does not by its very nature favour research on 'fashionable' topics and yielding short-term results, obstructing research of real or long-term significance for society (elementary research).272 Likewise, the reluctance to install effective control mechanisms targeting the activities of private or corporate actors providing finance to he institutions has made it possible for the activities of suchactors to compromise the independence of research inhe institutions. 273

271 See generally P.G. Altbach, 'Academic Freedom in a Global Context: 21st Century Challenges,' in The nea 2007 Almanac of Higher Education (National Education Association, 2007) 49-56, on the state of academic freedom in different parts of the world.

272 In this vein, see L. Bennich-Björkman, 'Has Academic Freedom Survived? An Interview Study of theConditions for Researchers in anEra of Paradigmatic Change,' Higher Education Quarterly 61(3) (2007) 334-361, at 348-352 (addressing research funding systems; the publication presents the results of an interview study of academic staff in Swedish universities, the results, according to the author, reflecting the general European experience). See also J. Thorens, 'Liberties, Freedom and Autonomy: Reflections on Academia's Estate,' HigherEducation Policy 19(1)(2006)87-110, at 100(critically discussing the role of research councils and funding decisions).

273 See Rendel (n 65) 83 (way back in 1988, before private industry funding assumed the importanceinhe ithasatpresent, warningthatthosecommissioningresearch 'maywantanswers only within their own frame of reference'); D. Robinson, 'Corrupting Research Integrity: Corporate Fundingand Academic Independence, 'in G. Sweeneyetal.(eds.), Global CorruptionReport:Education (Transparency International/Routledge, 2013) 202-210, 202, retrieved 15 May 2016, http://files.transparency.org/content/download/675/2899/file/2013_GCR _Education_EN.pdf (stating that ' $[\mathrm{t}]$ he increasing industrial sponsorship of universitybased research is raising widespread concerns about how these arrangements can corrupt and distort academic research'); M. Rostan, 'Challenges to Academic Freedom: Some EmpiricalEvidence,' EuropeanReview 18(Suppl. No.1)(2010) S71-S88, at S78-S80(commenting 
As has been indicated, only in very few cases does the law in Europe oblige he institutions to account to the public for private financing.

he institutions have become direct violators of academic freedom because they find themselves in an environment where they often cannot but violate that right. These days, he follows a neoliberal logic. Whereas it used to be a public good, paid for by the state, available free of charge to students, and based on the idea that (also) 'knowledge for its own sake' merits pursuit and transmission, he has now 'become the arm of national economic policy,' defined both as the problem, failing to produce a skilled workforce and marketable academic output, and the solution, in that it should upgrade skills and create a source of earnings. 274 The commercialisation of he is to go hand in hand with reductions in government spending for and 'new public management' methods in he.275 States consider that he institutions will use public money responsibly and produce 'measurable' outcome only, if they have to acquire a substantial part of funding through state and non-state sources themselves (by levying study fees, 'selling' academic 'merchandise' and 'services' (e.g. marketing intellectual property rights or carrying out commissioned

on the threats posed by researchfunding by privateactors);ibidS80-S85(commenting on thethreatsarisingfromlinksconnectingacademicstotheeconomicsector).

274 J. Blackmore, 'Globalisation: A Useful Concept for Feminists Rethinking Theories and Strategies in Education,' in N.C. Burbules and C.A. Torres (eds.), Globalisation and Education: Critical Perspectives (Routledge, 2000) 133-155, at 134. See T. Metz, 'A Dilemma Regarding Academic Freedom and Public Accountability in Higher Education,' Journal of Philosophy of Education 44(4) (2010) 529-549, on the notion that academic freedom also covers pursuing and transmitting 'knowledge for its own sake.'

275 On the commercialisation of and 'new public management' in he, see, e.g., R. Brown with H. Carasso, Everything for Sale? The Marketisation of uk Higher Education (Routledge, 2013), or A. McGettigan, The Great University Gamble: Money, Markets and the Future of HigherEducation (PlutoPress, 2013), regarding the uk; E. Schrecker, The Lost SoulofHigher Education: Corporatization, the Assault on Academic Freedom and the End of the American University (The New Press, 2010), regarding the usa; H. Woodhouse, Selling out: Academic Freedom and the Corporate Market (McGill-Queen's up, 2009), regarding Canada; C. Shore and M. Taitz, 'Who "Owns" the University? Institutional Autonomy and Academic Freedom in an Age of Knowledge Capitalism,' Globalisation, Societies and Education 10(2) (2012)201-219, regarding NewZealand. See generally H.G. Schuetzeetal.(eds.), University Governance and Reform: Policy, Fads, and Experience in International Perspective (Palgrave Macmillan, 2012); F. Rochford, 'Academic Freedom and the Ethics of Marketing Education,' in P. Tripathi and S. Mukerji (eds.), Cases on Innovations in Educational Marketing: Transnational and Technological Strategies (igi Global, 2011) 160-182. See W.G. Tierney and M. Lanford, 'The Question of Academic Freedom: Universal Right or Relative Term,' Frontiers of Education in China 9(1) (2014) 4-23, at 14-18, on 'Commercialization as a New Infringement on Academic Freedom.' See also the sources cited in $\mathrm{n} 282$ below. 
research), their academic staff applying for external research funding on a competitive basis and producing state income-generating publications, etc.), and further if they have to account for public money 'at every inch of the road' (internal and external audits, staff appraisals, student evaluations of staff, national research assessment exercises, etc.).276 This new model-substituting that in terms of which a solid measure of trust is placed in the competence of academics to be good teachers/researcher and responsible recipients of adequate finance-compels he institutions 'to do well' in he institution rankings, if they wish to remain able to attract fee-paying students and be awarded contracts for their academic 'merchandise' and 'services.' These rankings themselves apply questionable criteria of measuring excellence.277 They do not ask, for example, whether students from disadvantaged backgrounds can still afford

276 Ironically, therefore - although neoliberalism customarily advocates 'deregulation' - it has entailed a rise of standards and audits in he in practice. Frequently, these instruments have awkward consequences for the quality of teaching or research. The national uk researchassessmentexercises, e.g., require submission of acertainnumberof research outputs. In practice, this has meant an increased 'production' of shorter publications on 'easy' topics at the expense of more thoroughly researched, longer (including monograph) publications on 'more demanding' topics. Research is also required to 'have impact' beyond the institutional context. It may well be asked, how it should be shown, for instance, that a feminist critique has actually changed stereotyped attitudes. See S. Wright, 'What Counts? The Skewing Effects of Research Assessment Systems,' Nordisk Pedagogik 29 (special edition) (2009) 18-33, on the 'skewing effects' of research assessment systems. Also assessments of teaching performance potentially unjustifiably interfere with the right to academic freedom. See, e.g., W.Höfling, 'Die Lehrfreiheit: Gefährdungen eines Grundrechts durch die neuere Hochschulrechtsentwicklung?', Wissenschaftsrecht 41(2) (2008) 92-105. Although the article deals with the situation in Germany, most of its statements are equally applicable in a more general sense.

277 For a critique of university rankings, see, e.g., S. Amsler, 'University Ranking: A Dialogue on Turning towards Alternatives,' Ethicsin Science and Environmental Politics 13(2)(2013) 155-166; B.M. Kehm, 'Global University Rankings: Impacts and Unintended Side Effects,' European Journal of Education 49(1) (2014) 102-112; K. Lynch, 'New Managerialism, Neoliberalism and Ranking,' Ethics in Science and Environmental Politics 13(2) (2013) 141-153; B. Pusser and S. Marginson, 'University Rankings in Critical Perspective,' Journal of Higher Education 84(4) (2013) 544-568; D. Robinson, 'The Mismeasure of Higher Education? The Corrosive Effect of University Rankings,' Ethics in Science and Environmental Politics 13(2) (2013) 65-71; K.I. Stergiou and S. Lessenich, 'On Impact Factors and University Rankings: From Birth to Boycott,' Ethics in Science and Environmental Politics 13(2)(2013) 101-111; M. Taylor et al., 'Rankings are the Sorcerer's New Apprentice,' Ethics in Science and Environmental Politics 13(2) (2013) 73-99; S. Wright, 'Ranking Universities within a Globalised World of Competition States: To What Purpose, and with What Implications for Students?,' in H.L. Andersen and J.C. Jacobsen (eds.), Uddannelseskvalitet i en globaliseret verden (Samfundslitteratur, 2012) 81-102. 
good quality higher education. They do not enquire whether academic staff can exercise rights of academic freedom. They assess teaching quality quantitatively, but not by havingrecourse to scientifically soundqualitativemethods. They do not assess whether research addresses 'the majorquestions of humanity' and, moreover, does so in sufficient depth. Instead, the rankings rely upon: the volume of research income scaled against staff numbers, the "number of papers' published in 'high-quality peer-reviewed' journals, the 'number of citations' of published work, the ability 'to helpindustry with innovations, inventions, and consultancy,' opinion polls of 'experienced scholars,'278 or the 'satisfaction' of students. On the latter point, that of student satisfaction, it may be noted that this criterion, coupled with the fact that students are required to pay ever-increasing fees for their studies, has made them 'customers' of he, quasi-entitled to good marks and a qualification, with corresponding duties on teachers 'to deliver,' relinquishing the ideal of the student as a mature young adult bearing responsibilities also him/herself to master the subject.279 The new model in he also induces he institutions to compel academic staff to 'deliver' under 'target/performance agreements,' as staff output equals revenue. Usually imposed on staff, structured by revenue considerations, and their very premise being that the production of scientific truth can 'be planned,' 'target/ performance agreements' more often than not are highly arbitrary ('wissenschaftsinadäquat').280 It may further be noted that he institutions these days

278 See 'World University Rankings 2013-14 Methodology,' Times Higher Education, 1 October 2014, retrieved 15 May 2016, https://www.timeshighereducation.com/world-university -rankings-2013-14-methodology (mentioning inter alia the stated parameters; detailing 'the essential elements in our world-leading formula.').

279 For a critique of the notion of the student as 'customer,' see, e.g., M. Albanese, 'Students Are Not Customers: A Better Model for Medical Education,' Academic Medicine 74(11) (1999) 1172-1186; M.F. D'Eon and C. Harris, 'If Students Are Not Customers, What Are They?,' Academic Medicine 75(12) (2000) 1173-1177; L. Eagle and R. Brennan, 'Are Students Customers? tqm and Marketing Perspectives,' Quality Assurancein Education: An International Perspective 15(1)(2007)44-60; T. Kaye et al., 'Criticising the Image of the Student as Consumer: Examining Legal Trends and Administrative Responsesin theus anduk,' Educationandthe Law 18(2 \& 3)(2006) 85-129; J.A. Newson, 'Disruptingthe“Studentas Consumer" Model: The NewEmancipatory Project,' InternationalRelations 18(2)(2004)227-239; G. Svensson and G. Wood, 'Are University Students Really Customers? When Illusion May Lead to Delusion for All!,' International Journal of Educational Management 21(1)(2007) 17-28. See also M. Molesworthetal.(eds.), The Marketisationof Higher Educationandthe Studentas Consumer (Routledge, 2011). See D. Hayes, 'Academic Freedom and the Diminished Subject,' British Journal of Educational Studies 57(2) (2009) 127-145, at 143-144 (lamenting that a 'diminished' viewof humanityinhe institutionshasalsoentaileda 'diminished' viewof students).

280 Paragraph 47 of the unesco Recommendation on 'Appraisal' points out that the major function of evaluation must be "the development of individuals in accordance with their 
expectacademics to perform so many administrative tasks - preparing budget plans, seeking funding, etc. - that this has left them with less time to do what they do best - teaching and carrying out research.281 As borne out by the assessment undertaken here, the new model in he as described above is easiest implemented by engaging 'managers' of various sorts 'to control' academics/ teaching/research, by excluding academic staff from meaningful participation in decision-making, and by introducing 'executive-style' management in he. In sum, he institutions have become subject to various pressures resulting from the new design of he. Reacting to these pressures, these institutions themselves have become direct violators of academic freedom.

These 'developments' - which foreshadow the decline of European universities and other he institutions as entities of genuine public and social significance along the lines of their us American counterparts 282 - have their basis in legislation designed and implemented by the state, i.e. they are the consequence of deliberate state action. The state, therefore, 'pulling thestrings in the background,' is the ultimate human rights violator! In fact, the violation of the right to academic freedom has its root causes in the violation by states of another - the overarching - right to education. Article 13 of the International Covenant on Economic, Social and Cultural Rights, read with Article 2(1) of the Covenant, provides for the obligation of states parties - all states examined here having ratified the icescr - to take steps to the maximum of their available resources, with a view to progressively making he available and 'equally accessible to all, on the basis of capacity' (Art. 13(1),(2)(c)). There is an obligation to progressively introduce free he (Art. 13(2)(c)), to actively pursue

interests and capacities,' that it must be based 'only on academic criteria of competence,' and that it must 'take due account of the difficulty inherent in measuring personal capacity, which seldom manifests itself in a constant and unfluctuating manner,' (para. 47(a)-(c), respectively.).

281 See Bennich-Björkman (n 272) 352-354.

282 At least, such a 'decline' regarding he in the us has been held to have taken place. See, e.g., C. Nelson, No University is an Island: Saving Academic Freedom (New York up, 2010); C. Newfield, Unmaking the Public University: The Forty-Year Assault on the Middle Class (Harvard up, 2008); Schrecker(n 275). SeealsoIvoryTower (cnn Films 2014) (produced by A. Rossi). See B. Readings, The University in Ruins (Harvard up, 1996), or T. Docherty, Universities at War (sage, 2015), generally observing a decline of the university. As regards universities in Europe, see, e.g., J.C. Bermejo Barrera, La aurora de los enanos. Decadencia y caída de las universidades europeas (Foca, 2007). Specifically as regards universities in France, see, e.g., Beaud (n 128), in Germany, e.g., B.Zehnpfennig, 'Die Austreibung des Geistes aus der Universität,' Wissenschaftsrecht 46(1) (2013) 37-53, and in Spain, e.g., J. Hernández Alonso et al. (eds.), La universidad cercada: Testimonios de un naufragio (Anagrama, 2013). See also the sources cited in n 275 above. 
the development of a system of he institutions (Art. 13(2)(e)), and to continuously improve the material conditions of teaching staff in he (Art. 13(2)(e)).283 Article 13 shouldnotbeunderstoodas merely protecting 'aright toreceiveeducation.' It rather provides the normative basis for a full-fledged, rights-based education system, including in the sphere of he, also covering the rights of teaching/research staff.284Consequently, to the extent that states-relying on the maximum of their available resources - are in a position to finance he in such a way that it can be made available free of charge and that academic staff can properly attend to teaching and carrying out research 285 - and this may be held to be the case for most of the states examined, keeping in mind that international human rights law envisages general taxation as the principal model for financing education (study, teaching, and research) and other rights under the Covenant 286 - they must do so! In such circumstances, the principle of

283 With regard to the uk, the Committee on Economic, Social and Cultural Rights has thus 'note[d] with concern that the introduction of tuition fees and student loans, which is inconsistent with article 13, paragraph 2(c) ... has tended to worsen the position of students from less privileged backgrounds, who are already underrepresented in higher education.' See un, Committee on Economic, Social and Cultural Rights, Concluding Observations: United Kingdom of Great Britain and Northern Ireland, the Crown Dependencies and the Overseas Dependent Territories (4th periodic reports), 28th Session, un Doc.e/2003/22, para. 225. See Beiter (n 34) 387-388, 400-401,458, 526,572-573, 594, 651, generally on the topic of the legitimacy of study fees in he in the context of the icescr.

284 See,e.g., Beiter (n 34)460-462, in support of such a wide reading of Art. 13 icescr (citing in support of his view inter alia P. Gebert, Das Recht auf Bildung nach Art. 13 des unoPaktes über wirtschaftliche, soziale und kulturelle Rechte und seine Auswirkungen auf das schweizerische Bildungswesen (Leo Fürer, 1996) 286-288).

285 The obligation generally to have recourse to resources that are 'available' becomes clear from the statement by the Committee on Economic, Social and Cultural Rights (even if made only with regard to free he) on the report submitted by South Korea, to the effect that in that state party '[o]nly primary education is provided free of charge,' but that 'given the strength of the Korean economy it appears appropriate that free education should also extend to the ... higher[sector].' See un, Committee on Economic, Social and Cultural Rights, Concluding Observations: Republic of Korea (initial report), 12th Session, un Doc. E/1996/22, para. 76. In the case of the Czech Republic, the Committee referred to the 'constant decrease in the budget expenditure allocated to education and the consequences thereof on the enjoyment of the right to education,' and suggested to the Czech Republic that it 'consider increasing the budget allocation for education.' See un, Committee on Economic, Social and Cultural Rights, Concluding Observations: Czech Republic (initial report), 28th Session, un Doc. E/2003/22, paras. 91, 110.

286 The former un Special Rapporteur on the right to education, Katarina Tomaševski, has pointed out that '[i]nternational human rights law assumes that states are both willing and able to generate resources needed for education through general taxation.' See 
progressive realisation, as a matter of principle, forbids cutbacks of standards achieved.287 Hence, state legislation in Europe which compels he institutions, in their quest of ensuring their financial survival, to violate the right to academic freedom, also violates Article 13 icescr!

Envisaging 'a full-fledged, rights-based education system,' Article 13 icescr doesnotonlyaddressinfrastructure, access, andcosts. Article 13(1) 'recognise[s] theright of everyone to education,' stipulating the primary aim of education to be 'the full development of the human personality.'288 This relates tothequality or content of education provided, and, by necessary implication, also to the quality of teaching and research, and, therefore, to the rights and duties of academic staff in this context. 289 Nobel Literature laureate John Coetzee has remarked that 'allowing the transient needs of the economy to define the goals of highereducation is a misguided and short-sighted policy: indispensable to a democratic society-indeed, to a vigorous national economy-is a critically literate citizenry competent to explore and interrogate the assumptions behind the paradigms of national and economic life reigning at any given moment.'290 He goes on to point out that it is important to 'believe in the humanities and in the university built on humanistic grounds, with philosophical, historical and philological studies as its pillars.' 291 A he system which is 'the arm of national economic policy,' does not value the pursuit and transmission of 'knowledge for its own sake,' and does not breathe the full spirit of academic freedom can never further 'the full development of the human personality' of students. At the same time, it constitutes an assault on the dignity of academics and their profession. But, what is worse, such a he system ultimately erodes the very foundations of civilised society!

K. Tomaševski,Free and CompulsoryEducationforAllChildren:The GapBetweenPromise and Performance (Right to Education Primers, No. 2, 2001) 21.

287 This is clearly borne out by Paragraph 14(e) of the Maastricht Guidelines on Violations of Economic, Social and Cultural Rights of 1997, a document prepared by international experts on human rights and published in Human Rights Quarterly 20(3) (1998) 691-704.

288 See General Comment No. 13 (n 28) para. 4. See also Beiter (n 34) 470-471.

289 SeeGeneralCommentNo.13(n28)paras.38-40, insupportof the view that Art.13icescr covers the right to academic freedom. See also the observations to the same effect made by the former un Special Rapporteur on the right to education, Katarina Tomaševski, in two of her annual reports: Tomaševski (n 74) paras. 42-44; K. Tomaševski, Annual Report of the Special Rapporteur on the Right to Education, Submitted Pursuant to Commission on Human Rights Resolution 2001/29, un Doc. e/cn.4/2002/60 (7 January 2002) 13.

290 J.M. Coetzee, 'Foreword,' in J. Higgins (ed.), Academic Freedomina Democratic South Africa: Essays and Interviews on Higher Education and the Humanities (Bucknell up, 2014) xi, xii.

291 Ibid xiii. 
Academic Freedom in the Law of European States

Annex: Legal Protection of the Right to Academic Freedom in Europe - Overview of Results forAll Indicatorsfor IndividualCountries

\begin{tabular}{ll}
\hline Country & $\begin{array}{l}\text { A. Ratification of International Agreements and } \\
\text { Constitutional Protection }\end{array}$
\end{tabular}

1. 1.1 .1 . 1.1 .2 . 1.1 .3 . 1.1 .4 . 1.2 . 2 . 2.1 .2 .2 .2 .3 .

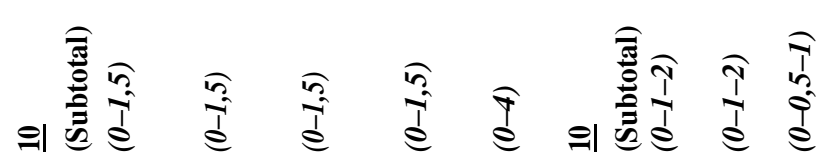

\begin{tabular}{lllllllllll}
\hline 1. Austria & 8,5 & $(1,5)$ & $(1,5)$ & $(1,5)$ & $(0)$ & $(4)$ & 9 & $(2)$ & $(2)$ & $(1)$ \\
2.1. Belgium: Flanders & 10 & $(1,5)$ & $(1,5)$ & $(1,5)$ & $(1,5)$ & $(4)$ & 4 & $(2)$ & $(0)$ & $(0)$ \\
2.2. Belgium: Wallonia & 10 & $(1,5)$ & $(1,5)$ & $(1,5)$ & $(1,5)$ & $(4)$ & 4 & $(2)$ & $(0)$ & $(0)$ \\
3. Bulgaria & 8,5 & $(1,5)$ & $(1,5)$ & $(1,5)$ & $(0)$ & $(4)$ & 9 & $(2)$ & $(2)$ & $(1)$ \\
4. Croatia & 8,5 & $(1,5)$ & $(1,5)$ & $(1,5)$ & $(0)$ & $(4)$ & 9 & $(2)$ & $(2)$ & $(1)$ \\
5. Cyprus & 8,5 & $(1,5)$ & $(1,5)$ & $(1,5)$ & $(0)$ & $(4)$ & 4 & $(2)$ & $(0)$ & $(0)$ \\
6. Czech Republic & 8,5 & $(1,5)$ & $(1,5)$ & $(1,5)$ & $(0)$ & $(4)$ & 7 & $(2)$ & $(1)$ & $(0)$ \\
7. Denmark & 8,5 & $(1,5)$ & $(1,5)$ & $(1,5)$ & $(0)$ & $(4)$ & 4 & $(2)$ & $(0)$ & $(0)$ \\
8. Estonia & 8,5 & $(1,5)$ & $(1,5)$ & $(1,5)$ & $(0)$ & $(4)$ & 9 & $(2)$ & $(2)$ & $(1)$ \\
9. Finland & 10 & $(1,5)$ & $(1,5)$ & $(1,5)$ & $(1,5)$ & $(4)$ & 9 & $(2)$ & $(2)$ & $(1)$ \\
10. France & 10 & $(1,5)$ & $(1,5)$ & $(1,5)$ & $(1,5)$ & $(4)$ & 4 & $(2)$ & $(0)$ & $(0)$ \\
11.1. Germany: Bavaria & 8,5 & $(1,5)$ & $(1,5)$ & $(1,5)$ & $(0)$ & $(4)$ & 9 & $(2)$ & $(2)$ & $(0)$ \\
11.2. Germany: N.R.W. & 8,5 & $(1,5)$ & $(1,5)$ & $(1,5)$ & $(0)$ & $(4)$ & 9 & $(2)$ & $(2)$ & $(1)$ \\
12. Greece & 8,5 & $(1,5)$ & $(1,5)$ & $(1,5)$ & $(0)$ & $(4)$ & 7 & $(1)$ & $(1)$ & $(1)$ \\
13. Hungary & 8,5 & $(1,5)$ & $(1,5)$ & $(1,5)$ & $(0)$ & $(4)$ & 3 & $(0)$ & $(1)$ & $(0)$ \\
14. Ireland & 8,5 & $(1,5)$ & $(1,5)$ & $(1,5)$ & $(0)$ & $(4)$ & 3 & $(1)$ & $(0)$ & $(0)$ \\
15. Italy & 10 & $(1,5)$ & $(1,5)$ & $(1,5)$ & $(1,5)$ & $(4)$ & 9 & $(2)$ & $(2)$ & $(1)$ \\
16. Latvia & 8,5 & $(1,5)$ & $(1,5)$ & $(1,5)$ & $(0)$ & $(4)$ & 8 & $(2)$ & $(2)$ & $(0)$ \\
17. Lithuania & 8,5 & $(1,5)$ & $(1,5)$ & $(1,5)$ & $(0)$ & $(4)$ & 9 & $(2)$ & $(2)$ & $(1)$ \\
18. Luxemburg & 10 & $(1,5)$ & $(1,5)$ & $(1,5)$ & $(1,5)$ & $(4)$ & 4 & $(2)$ & $(0)$ & $(0)$ \\
19. Malta & 7 & $(0)$ & $(1,5)$ & $(1,5)$ & $(0)$ & $(4)$ & 4 & $(2)$ & $(0)$ & $(0)$ \\
20. Netherlands & 8,5 & $(1,5)$ & $(1,5)$ & $(1,5)$ & $(0)$ & $(4)$ & 4 & $(2)$ & $(0)$ & $(0)$ \\
21. Poland & 8,5 & $(1,5)$ & $(1,5)$ & $(1,5)$ & $(0)$ & $(4)$ & 9 & $(2)$ & $(2)$ & $(1)$ \\
22. Portugal & 10 & $(1,5)$ & $(1,5)$ & $(1,5)$ & $(1,5)$ & $(4)$ & 10 & $(2)$ & $(2)$ & $(1)$
\end{tabular}




\section{B. Express C. Protection of Institutional Autonomy in HE Legislation}

\section{Protection}

of Academic

Freedom

in $\mathrm{HE}$

Legislation

2.4. 2.5 .

1. 2. 2.1.1. 2.1.2. 2.2.1. 2.2.2. 2.3. 2.4.1. 2.4.2. 3 . 4 .

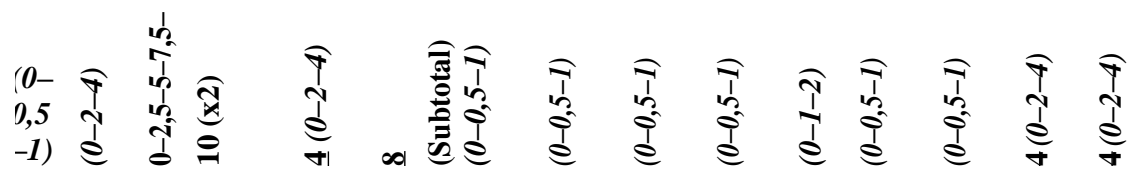

$\begin{array}{lllllllllllll}(0) & \text { (4) } 10 \times 2=20 & 2 & 6 & \text { (1) } & \text { (1) } & \text { (1) } & \text { (1) } & \text { (1) } & \text { (0) } & \text { (1) } & 2 & 2\end{array}$

$\begin{array}{lllllllllllll}\text { (0) (2) } \quad 5 \times 2=10 & 2 & 4,5 & \text { (1) } & \text { (1) } & \text { (1) } & (0,5) & \text { (1) } & \text { (0) } & \text { (0) } & 4 & 0\end{array}$

$\begin{array}{lllllllllllll}\text { (0) } \quad(2) \quad 5 \times 2=10 & 2 & 2,5 & (0) & (1) & (0,5) & (0,5) & (0) & (0) & (0,5) & 2 & 0\end{array}$

$\begin{array}{lllllllllllll}\text { (0) (4) } \quad 7,5 \times 2=15 & 4 & 3 & (1) & (0) & (0,5) & (1) & (0) & (0,5) & (0) & 2 & 0\end{array}$

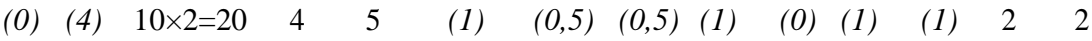

$\begin{array}{lllllllllllll}\text { (0) } \quad(2) \quad 5 \times 2=10 & 2 & 2 & (1) & (0) & (0) & (0,5) & (0) & (0,5) & (0) & 2 & 2\end{array}$

$\begin{array}{lllllllllllll}\text { (0) }(4) & 7,5 \times 2=15 & 4 & 2 & (0) & (0,5) & (0,5) & (0,5) & (0) & (0,5) & (0) & 2 & 0\end{array}$

$\begin{array}{lllllllllllll}\text { (0) (2) } 2,5 \times 2=5 & 2 & 5 & \text { (1) } & \text { (1) } & \text { (1) } & \text { (1) } & \text { (1) } & \text { (0) } & \text { (0) } & 0 & 2\end{array}$

$\begin{array}{llllllllllllll}\text { (0) } & \text { (4) } & 0 & 2 & 6,5 & \text { (1) } & \text { (1) } & \text { (1) } & \text { (1) } & \text { (1) } & \text { (1) } & (0,5) & 2 & 0\end{array}$

$\begin{array}{lllllllllllll}\text { (0) (4) } 7,5 \times 2=15 & 4 & 7 & \text { (1) } & \text { (1) } & (0,5) & \text { (1) } & \text { (2) } & \text { (1) } & (0,5) & 4 & 0\end{array}$

$\begin{array}{lllllllllllll}\text { (0) } \quad(2) \quad 10 \times 2=20 & 2 & 3 & (1) & (0,5) & (0,5) & (1) & (0) & (0) & (0) & 2 & 0\end{array}$

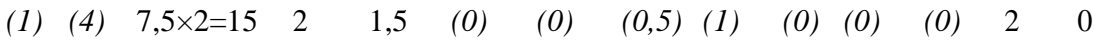

$\begin{array}{lllllllllllll}\text { (0) (4) } 10 \times 2=20 & 2 & 5 & \text { (1) } & \text { (1) } & \text { (1) } & \text { (1) } & \text { (1) } & \text { (0) } & \text { (0) } & 2 & 4\end{array}$

$\begin{array}{lllllllllllll}\text { (0) } \quad(4) \quad 2,5 \times 2=5 & 2 & 0,5 & (0) & (0) & (0) & (0,5) & (0) & (0) & (0) & 2 & 0\end{array}$

$\begin{array}{lllllllllllll}\text { (0) } \quad(2) \quad 2,5 \times 2=5 & 0 & 2,5 & (0) & (0,5) & (0,5) & (0,5) & (0) & (1) & (0) & 0 & 0\end{array}$

$\begin{array}{lllllllllllll}\text { (0) (2) } \quad 7,5 \times 2=15 & 2 & 6,5 & \text { (1) } & \text { (1) } & \text { (1) } & (0,5) & \text { (1) } & \text { (1) } & \text { (1) } & 4 & 0\end{array}$

$\begin{array}{lllllllllllll}\text { (0) } \quad(4) \quad 5 \times 2=10 & 2 & 3 & (0) & (0,5) & (1) & (0,5) & (0) & (1) & (0) & 2 & 2\end{array}$

$\begin{array}{lllllllllllll}\text { (0) (4) } \quad 10 \times 2=20 & 2 & 4 & (0) & (1) & (0,5) & (1) & (1) & (0,5) & (0) & 4 & 0\end{array}$

$\begin{array}{lllllllllllll}\text { (0) (4) } \quad 10 \times 2=20 & 4 & 5 & \text { (1) } & (1) & (0,5) & (1) & \text { (1) } & (0,5) & (0) & 2 & 0\end{array}$

$\begin{array}{lllllllllllll}\text { (0) (2) } 7,5 \times 2=15 & 2 & 5 & (0) & (0) & \text { (1) } & \text { (1) } & \text { (1) } & \text { (1) } & \text { (1) } & 2 & 0\end{array}$

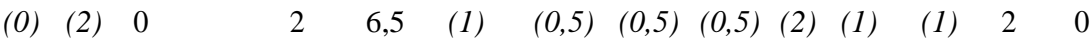

$\begin{array}{lllllllllllll}\text { (0) (2) } \quad 5 \times 2=10 & 2 & 5 & (0,5) & (0,5) & (1) & (0,5) & (2) & (0,5) & (0) & 2 & 0\end{array}$

$\begin{array}{lllllllllllll}\text { (0) (4) } 5 \times 2=10 & 2 & 5,5 & \text { (1) } & \text { (1) } & (0,5) & (1) & \text { (1) } & (0,5) & (0,5) & 2 & 0\end{array}$

$\begin{array}{lllllllllllll}\text { (1) }(4) \quad 5 \times 2=10 & 4 & 3 & (0,5) & (0,5) & (0,5) & (1) & (0) & (0,5) & (0) & 2 & 0\end{array}$ 
Country

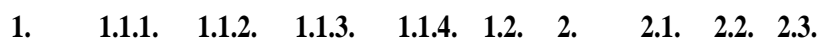

A. Ratification of International Agreements and

\section{Constitutional Protection}

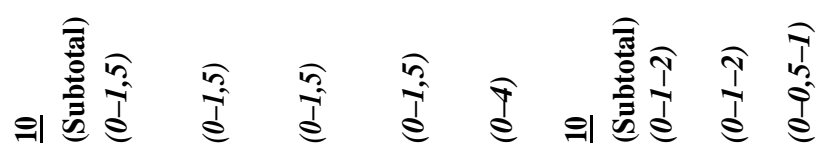

$\begin{array}{lllllllllll}\text { 23. Romania } & 8,5 & (1,5) & (1,5) & (1,5) & (0) & (4) & 4 & (1) & (0) & (1) \\ \text { 24. Slovakia } & 10 & (1,5) & (1,5) & (1,5) & (1,5) & (4) & 8 & (2) & (2) & (0) \\ \text { 25. Slovenia } & 8,5 & (1,5) & (1,5) & (1,5) & (0) & (4) & 9 & (2) & (2) & (1) \\ \text { 26. Spain } & 10 & (1,5) & (1,5) & (1,5) & (1,5) & (4) & 10 & (2) & (2) & (1) \\ \text { 27. Sweden } & 8,5 & (1,5) & (1,5) & (1,5) & (0) & (4) & 8 & (2) & (2) & (0) \\ \text { 28. uk } & 7 & (1,5) & (0) & (1,5) & (0) & (4) & 4 & (2) & (0) & (0)\end{array}$

Country

D.Protection of Academic Self-Governance in HE Legislation

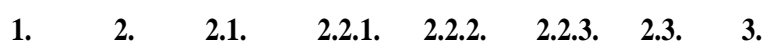

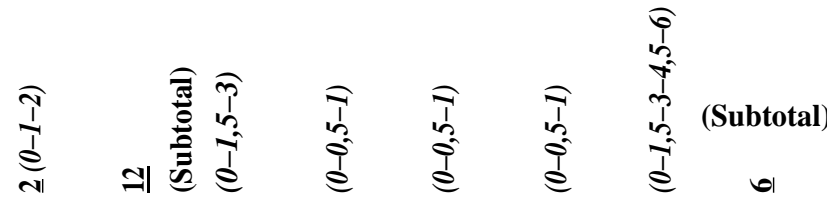

$\begin{array}{lllllllll}\text { 1. Austria } & 1 & 7 & (3) & (0) & (0,5) & (0,5) & (3) & 1 \\ \text { 2.1. Belgium: Flanders } & 0 & 6 & (0) & (1) & (0,5) & (0) & (4,5) & 1 \\ \text { 2.2. Belgium: Wallonia } & 0 & 8 & (1,5) & (1) & (0,5) & (0,5) & (4,5) & 0 \\ \text { 3. Bulgaria } & 1 & 9,5 & (1,5) & (1) & (0,5) & (0,5) & (6) & 4\end{array}$




\section{B. Express C. Protection of Institutional Autonomy in HE Legislation}

\section{Protection}

of Academic

\section{Freedom}

in $\mathrm{HE}$

Legislation

1. 2. 2.1.1. 2.1.2. 2.2.1. 2.2.2. 2.3. 2.4.1. 2.4.2. 3.4 .

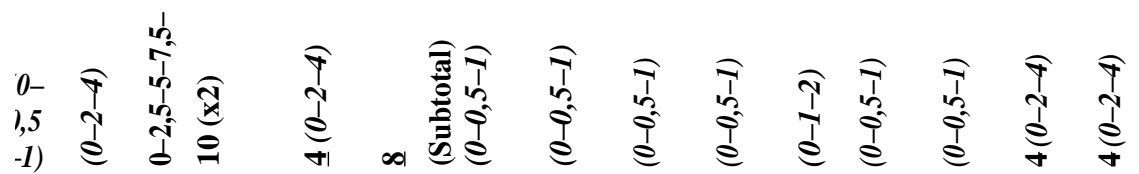
(0) (2) $7,5 \times 2=15 \quad 4 \quad 2$
(0)
(0) $\quad(0,5)(1)$
(0) $\quad(0,5)(0) \quad 2 \quad 0$
(0) (4) $10 \times 2=20 \quad 4$
$2,5 \quad(0)$
$(0,5) \quad(0,5) \quad(1)$

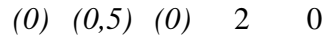
(0) (4) $2,5 \times 2=5 \quad 2 \quad 4,5 \quad(1)$
$\begin{array}{lllllllll}(1) & (0,5) & (0,5) & (1) & (0,5) & (0) & 2 & 0\end{array}$
(1) (4) $7,5 \times 2=15 \quad 4$
$2,5 \quad(0)$
(0)
(1)
$\begin{array}{llllll}(1) & (0) & (0,5) & (0) & 2 & 0\end{array}$
(0) (4) $2,5 \times 2=5 \quad 2 \quad 4,5 \quad(0)$
(1) $\quad(0,5) \quad(0,5)$
(2) $(0,5)(0) \quad 0 \quad 0$
$7,5 \quad(1)$
(1) (1) $\quad(0,5)$
(2) (1) (1) $4 \quad 0$

(0) (2) $2,5 \times 2=5 \quad 2$

E. Job Security (including 'Tenure') in Relevant

\section{Legislation}

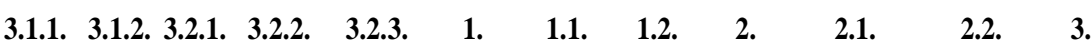

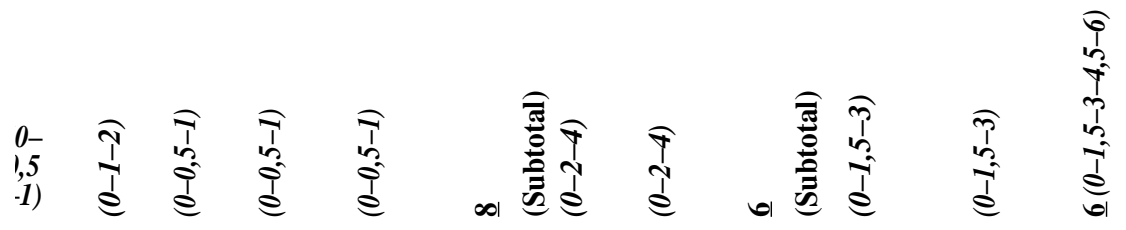

$\begin{array}{llllllllllll}(0) & (0) & (0,5) & (0,5) & (0) & 2 & (2) & (0) & 1,5 & (1,5) & (0) & 1,5 \\ (1) & (0) & (0) & (0) & (0) & 4 & (4) & (0) & 3 & (1,5) & (1,5) & 3 \\ (0) & (0) & (0) & (0) & (0) & 4 & (4) & (0) & 3 & (1,5) & (1,5) & 1,5 \\ (1) & (1) & (1) & (0,5) & (0,5) & 8 & (4) & (4) & 1,5 & (1,5) & (0) & 0\end{array}$


Academic Freedom in the Law of European States

Country

D.Protection of AcademicSelf-Governance in HELegislation

$\begin{array}{llllllll}\text { 1. } & 2 . & 2.1 . & 2.2 .1 . & 2.2 .2 . & 2.2 .3 . & 2.3 . & 3 \text {. }\end{array}$

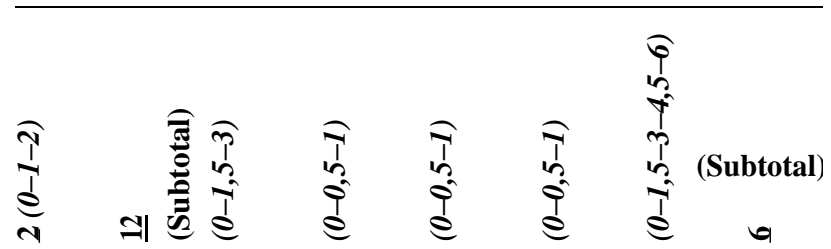

\begin{tabular}{lllllllll}
\hline 4. Croatia & 1 & 9,5 & $(1,5)$ & $(1)$ & $(0,5)$ & $(0,5)$ & $(6)$ & 3,5 \\
5. Cyprus & 0 & 7,5 & $(3)$ & $(1)$ & $(0,5)$ & $(0)$ & $(3)$ & 5 \\
6. Czech Republic & 1 & 7 & $(1,5)$ & $(0)$ & $(0,5)$ & $(0,5)$ & $(4,5)$ & 3 \\
7. Denmark & 1 & 3,5 & $(1,5)$ & $(0,5)$ & $(0)$ & $(0)$ & $(1,5)$ & 2 \\
8. Estonia & 0 & 3,5 & $(0)$ & $(0,5)$ & $(0)$ & $(0)$ & $(3)$ & 1 \\
9. Finland & 0 & 2 & $(0)$ & $(0,5)$ & $(0)$ & $(0)$ & $(1,5)$ & 1 \\
10. France & 1 & 3,5 & $(0)$ & $(0,5)$ & $(0)$ & $(0)$ & $(3)$ & 2 \\
11.1. Germany: Bavaria & 2 & 6 & $(1,5)$ & $(0,5)$ & $(0,5)$ & $(0,5)$ & $(3)$ & 4 \\
11.2. Germany: N.R.W. & 2 & 7 & $(1,5)$ & $(0)$ & $(0,5)$ & $(0,5)$ & $(4,5)$ & 3,5 \\
12. Greece & 0 & 7 & $(1,5)$ & $(0,5)$ & $(0,5)$ & $(0)$ & $(4,5)$ & 3,5 \\
13. Hungary & 0 & 9 & $(3)$ & $(0,5)$ & $(0,5)$ & $(0,5)$ & $(4,5)$ & 0 \\
14. Ireland & 0 & 3 & $(1,5)$ & $(0)$ & $(0)$ & $(0)$ & $(1,5)$ & 0 \\
15. Italy & 0 & 6 & $(3)$ & $(0,5)$ & $(0,5)$ & $(0,5)$ & $(1,5)$ & 2 \\
16. Latvia & 2 & 7 & $(1,5)$ & $(0,5)$ & $(0,5)$ & $(0)$ & $(4,5)$ & 1,5 \\
17. Lithuania & 1 & 5 & $(0)$ & $(0,5)$ & $(0)$ & $(0)$ & $(4,5)$ & 0 \\
18. Luxemburg & 0 & 3,5 & $(1,5)$ & $(0,5)$ & $(0)$ & $(0)$ & $(1,5)$ & 2,5 \\
19. Malta & 0 & 3 & $(1,5)$ & $(0)$ & $(0)$ & $(0)$ & $(1,5)$ & 3 \\
20. Netherlands & 1 & 3 & $(0)$ & $(0)$ & $(0)$ & $(0)$ & $(3)$ & 1,5 \\
21. Poland & 1 & 9 & $(1,5)$ & $(1)$ & $(0)$ & $(0,5)$ & $(6)$ & 2,5 \\
22. Portugal & 1 & 9 & $(1,5)$ & $(0,5)$ & $(0,5)$ & $(0,5)$ & $(6)$ & 1,5 \\
23. Romania & 1 & 8 & $(1,5)$ & $(0,5)$ & $(0,5)$ & $(1)$ & $(4,5)$ & 3,5 \\
24. Slovakia & 1 & 8,5 & $(1,5)$ & $(0)$ & $(0,5)$ & $(0,5)$ & $(6)$ & 3 \\
25. Slovenia & 0 & 7 & $(1,5)$ & $(0)$ & $(1)$ & $(0)$ & $(4,5)$ & 4 \\
26. Spain & 0 & 8,5 & $(3)$ & $(1)$ & $(0,5)$ & $(1)$ & $(3)$ & 3,5 \\
27. Sweden & 0 & 3 & $(1,5)$ & $(0)$ & $(0)$ & $(0)$ & $(1,5)$ & 0 \\
28. UK & 0 & 0 & $(0)$ & $(0)$ & $(0)$ & $(0)$ & $(0)$ & 0 \\
& & & & & & & & \\
& & & & & & & & \\
& & & & & & & &
\end{tabular}


Beiter, Karran and Appiagyei-Atua

E. Job Security (including 'Tenure') in Relevant

\section{Legislation}

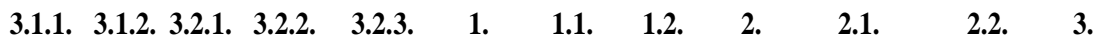

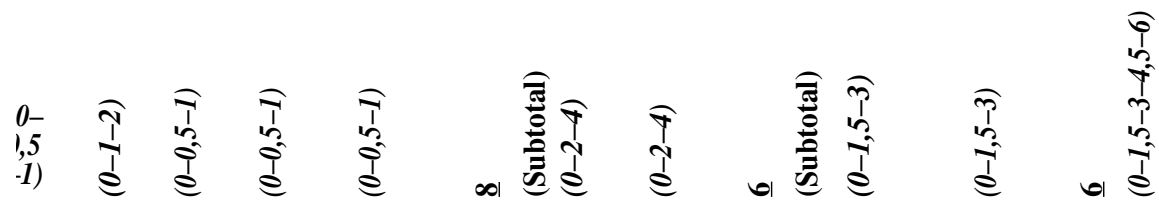

$\begin{array}{llllllllllll}(1) & (1) & (0,5) & (0,5) & (0,5) & 0 & (0) & (0) & 4,5 & (1,5) & (3) & 0\end{array}$

$\begin{array}{lllllllllll}(1) & (2) & (1) & (1) & (0) & 4 & (2) & (2) & 3 & (1,5) & (1,5)\end{array}$

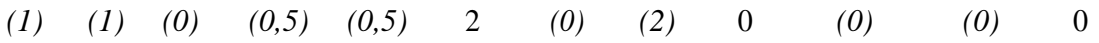

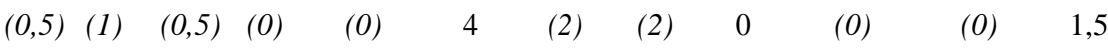

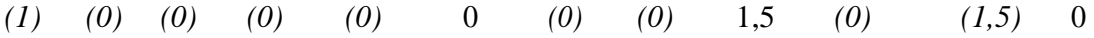

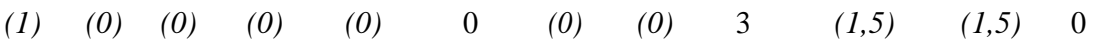

$\begin{array}{lllllllllll}(1) & (0) & (1) & (0) & (0) & 8 & (4) & (4) & 4,5 & (1,5) & \text { (3) }\end{array}$

$\begin{array}{lllllllllll}(1) & (1) & (1) & (0,5) & (0,5) & 2 & \text { (2) } & (0) & 4,5 & (1,5) & \text { (3) }\end{array}$

$\begin{array}{llllllllllll}(1) & (1) & (0,5) & (0,5) & (0,5) & 2 & (2) & (0) & 4,5 & (1,5) & \text { (3) } & 1,5\end{array}$

$\begin{array}{lllllllllll}(1) & (1) & (1) & (0,5) & (0) & 8 & \text { (4) } & \text { (4) } & 6 & \text { (3) } & \text { (3) }\end{array}$

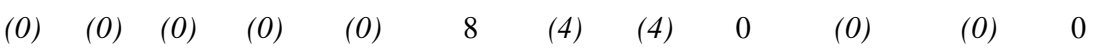

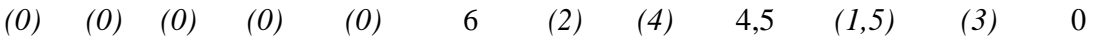

$\begin{array}{lllllllllll}(1) & (1) & (0) & (0) & (0) & 4 & (2) & (2) & 4,5 & (1,5) & (3)\end{array}$

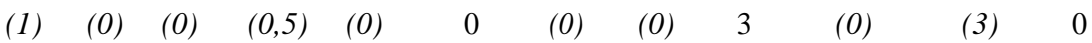

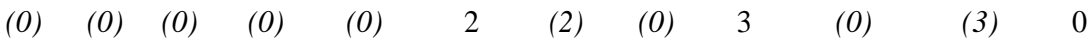

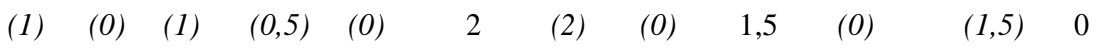

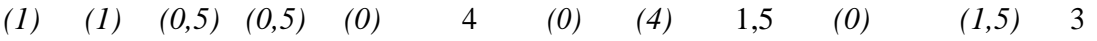

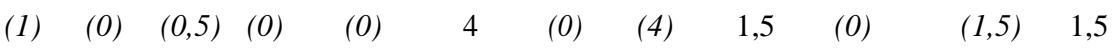

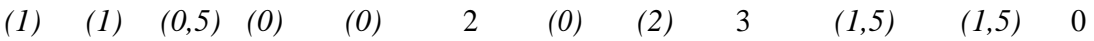

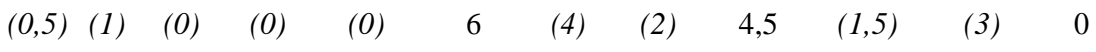

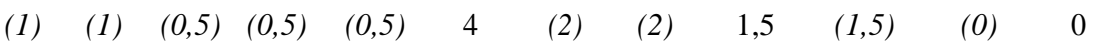

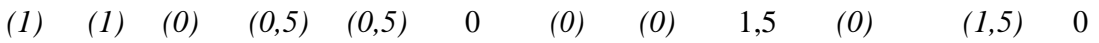

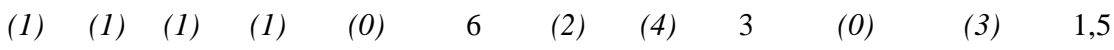

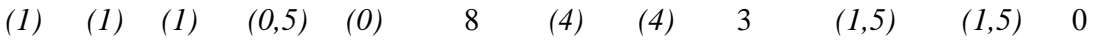

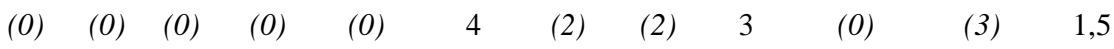

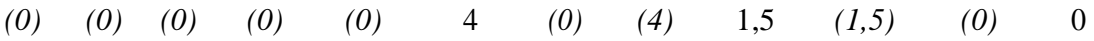

